UNIVERSIDADE DE SÃO PAULO

ESCOLA DE ARTES, CIÊNCIAS E HUMANIDADES

PROGRAMA DE PÓS-GRADUAÇÃO EM TURISMO

CLARISSA CAMPOS QUIARARIA

Hospitalidade Pública:

O caso da Praça Gustavo Teixeira em São Pedro, SP. 


\section{Hospitalidade Pública:}

O caso da Praça Gustavo Teixeira em São Pedro, SP.

Dissertação apresentada à Escola de Artes, Ciências e Humanidades da Universidade de São Paulo para obtenção do título de Mestre em Ciências pelo Programa de Pós-Graduação em Turismo.

Versão corrigida contendo as alterações solicitadas pela comissão julgadora em 08 de junho de 2018. A versão original encontra-se em acervo reservado na Biblioteca da EACH/USP e na Biblioteca Digital de Teses e Dissertações da USP (BDTD), de acordo com a Resolução CoPGr 6018, de 13 de outubro de 2011.

Área de Concentração:

Desenvolvimento do Turismo

Orientador:

Prof. Dr. Alexandre Panosso Netto 
Autorizo a reprodução e divulgação total ou parcial deste trabalho, por qualquer meio convencional ou eletrônico, para fins de estudo e pesquisa, desde que citada a fonte.

CATALOGAÇÃO-NA-PUBLICAÇÃO

(Universidade de São Paulo. Escola de Artes, Ciências e Humanidades. Biblioteca) CRB $8-4936$

Quiararia, Clarissa Campos

Hospitalidade pública: o caso da Praça Gustavo Teixeira em

São Pedro, SP / Clarissa Campos Quiararia ; orientador,

Alexandre Panosso Netto. - 2018.

$83 \mathrm{f}$ : : il

Dissertação (Mestrado em Ciências) - Programa de Pós-

Graduação em Turismo, Escola de Artes, Ciências e

Humanidades, Universidade de São Paulo Versão corrigida

1. Hospitalidade - São Pedro (SP). 2. Praças - São

Pedro (SP). I. Panosso Netto, Alexandre, orient. II. Título.

CDD 22.ed. -910.4098161 
Nome: QUIARARIA, Clarissa Campos

Título: Hospitalidade Pública: O caso da Praça Gustavo Teixeira em São Pedro, SP.

Dissertação apresentada à Escola de Artes, Ciências e Humanidades da Universidade de São Paulo para obtenção do título de Mestre em Ciências pelo Programa de Pós-Graduação em Turismo.

Área de Concentração:

Desenvolvimento do Turismo

Aprovado em: 08 de junho de 2018.

\section{Banca Examinadora}

Prof. Dr. Luiz Octávio de Lima Camargo

Universidade de São Paulo / Universidade Anhembi Morumbi

Profa. Dra. Sênia Regina Bastos

Universidade Anhembi Morumbi

Profa. Dra. Cynthia Mello

Semioturismo 
À minha família por sempre acreditar em mim! 


\section{AGRADECIMENTOS}

Agradeço, primeiramente, a Deus pela força de caminhar até aqui.

À minha família por estar ao meu lado, me encorajar e acreditar que tudo era possível.

Ao meu marido pela paciência, pelas palavras de carinho e pelo incentivo.

Aos amigos, ah os amigos. Obrigada por estarem ao meu lado sempre.

Ao querido amigo e professor Edilson Galante pelo aprendizado no momento final da formatação.

Ao meu orientador, Professor Doutor Alexandre Panosso Netto, pelas orientações, pelos aconselhamentos, ensinamentos e, acima de tudo, pela confiança depositada em mim.

Ao Prefeito Hélio Donizete Zanatta por perceber a importância desse estudo para o desenvolvimento turístico de São Pedro.

À Escola de Ciências, Artes e Humanidades (EACH), da Universidade de São Paulo (USP) por me proporcionar aprendizados e experiências inspiradoras. Mestres, eternos mestres, obrigada!

Aos colegas de mestrado, sobretudo Ana Clemente, Ticiana Oliveira e Wallace Farias. Sou eternamente grata às trocas de experiências e aconselhamentos dentro e fora da sala de aula.

Aos entrevistados, que mesmo anonimamente, foram peças-chaves para a construção dessa pesquisa.

E, finalmente, à cidade de São Pedro por ser minha segunda casa! 
Só se vê o bem com o coração, o essencial é invisível aos olhos.

(EXUPÉRY, 1986, p.74) 


\section{RESUMO}

QUIARARIA, Clarissa Campos. Hospitalidade Pública: O caso da Praça Gustavo Teixeira em São Pedro, SP. 2018. 83 f. Dissertação (Mestrado em Ciências) - Escola de Artes, Ciências e Humanidades, Universidade de São Paulo, 2018. Versão Corrigida.

O presente estudo teve como objetivo identificar e analisar como a hospitalidade pública se manifesta na Praça Gustavo Teixeira, em São Pedro, Estado de São Paulo, a partir das relações estabelecidas entre moradores e turistas, tendo como base as dimensões de acessibilidade, legibilidade e identidade. A metodologia utilizada foi uma combinação de pesquisa bibliográfica e documental, fundamentada em documentos de arquivos públicos, fotografias e mapas da Prefeitura Municipal de São Pedro; relatórios de pesquisa baseados em trabalho de campo de auxiliares. Dentre as técnicas de coleta de dados estão observação sistemática e pesquisa de caráter qualitativo, exploratória e com questões semiestruturadas e abertas, o que permitiu um melhor direcionamento no decorrer da conversa informal. O grupo de entrevistados divide-se em moradores, composto por seis pessoas que possuem envolvimento com o local de pesquisa em todos os momentos da vida; e visitantes, composto por mais seis pessoas que não possuem envolvimento diário com o local. Constatou-se que a maioria dos moradores visita a Praça diariamente; suas falas são repletas de sentimentos pelo local; percebem, nitidamente, uma interação com outros moradores e com turistas; a dimensão da acessibilidade, por meio da localização, da qualidade das vias de acesso, da divulgação das atividades, está presente; a legibilidade, por sua vez, faz-se nítida por possuir área verde, bancos, coreto, tranquilidade de cidade do interior; e, por fim, a identidade é percebida na forma como os anfitriões conversam, nas atividades realizadas - teatro, música, literatura, quermesse, museu que leva o nome do poeta. Já o grupo de turistas visita a Praça quase todas as vezes que está na Estância, com exceção de um integrante que a visitou pela primeira vez; são motivados pela natureza e pela segurança característica de cidade pequena - ao deixar os filhos brincarem em meio ao espaço verde; notam um acolhimento por parte dos moradores, tanto na Praça quanto no comércio do entorno; a acessibilidade é percebida pelas informações passadas em pontos de informações turísticas, no comércio, na internet, na fácil localização por estar no centro da cidade; a dimensão da legibilidade faz-se presente no espaço verde em meio ao urbano, nas lembranças da infância e no encontro com amigos; já a identidade é percebida no artesanato e na gastronomia do entorno, na relação amigável entre as pessoas.

Palavras-Chave: Hospitalidade Pública. Praça Gustavo Teixeira. Acessibilidade. Legibilidade. Identidade. 


\begin{abstract}
QUIARARIA, Clarissa Campos. Public Hospitality: The case of the Gustavo Teixeira Square in São Pedro, SP. 2018. 83 p. Dissertation (Master of Science) - School of Arts, Sciences and Humanities, University of São Paulo, São Paulo, 2018. Corrected Version.
\end{abstract}

The present study aimed to identify and analyze how public hospitality is manifested in Gustavo Teixeira Square, in São Pedro, State of São Paulo, based on relationships established between residents and tourists, based on the accessibility, readability and identity dimensions. The methodology used was a combination of bibliographical and documentary research, based on public records documents, photographs and maps of the São Pedro City Hall; research reports based on auxiliary field work. Among the techniques of data collection are observation systematic and qualitative, exploratory research with semi structured and open questions, which allowed a better targeting during the informal conversation. The group of interviewees is divided into residents, composed of six people who have involvement with the research site at all times of life; and visitors, composed of another six people who do not have daily involvement with the place. It was verified that the residents visit the Square daily; their lines are full of feelings for the place; they perceive, clearly, an interaction with other residents and tourists; the accessibility dimension, through location, the quality of the access roads, the dissemination of activities, is present; the readability, in turn, is made clear by having green area, benches, gazebo, tranquility of inner city; and, finally, the identity is perceived in the way the hosts talk, in the activities performed - theater, music, literature, kermesse, museum that bears the name of the poet. Already the group of tourists visits the Square every time it is in the Estancia, except for one member who visited it for the first time; are motivated by the nature and safety characteristic of a small town - by letting their children play in the green space; they notice a welcome on the part of the residents, both in the Square and in the commerce of the surroundings; the accessibility is perceived by the information passed in points of tourist information, in the commerce, in the internet, in the easy location for being in the center of the city; the dimension of readability is present in the green space in the middle of the urban, in the memories of childhood and in the encounter with friends; already the identity is perceived in the crafts and in the gastronomy of the surroundings, in the friendly relationship between the people.

Keywords: Public Hospitality. Gustavo Teixeira Square. Accessibility. Readability. Identity. 


\section{LISTA DE FIGURAS}

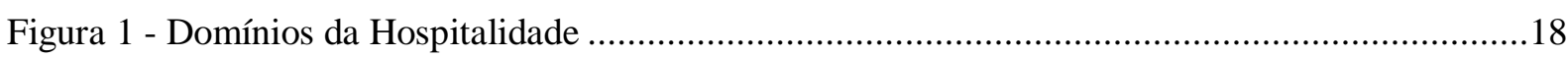

Figura 2 - Alunos do Grupo Escolar em atividade externa......................................................................34

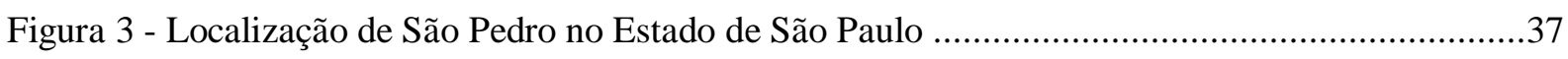

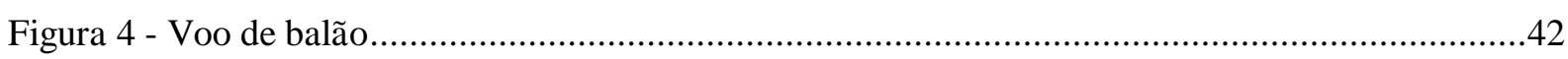

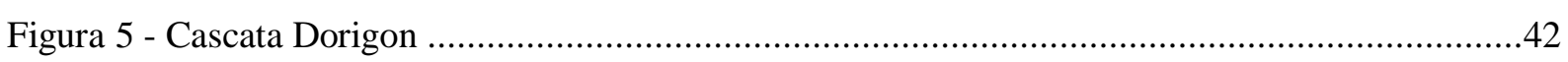

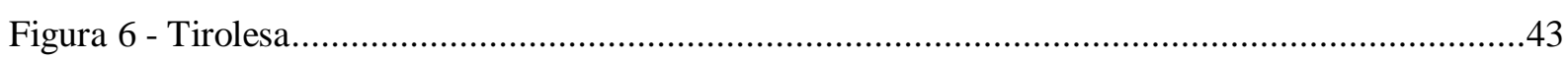

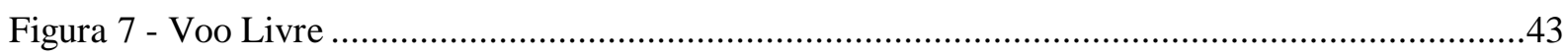

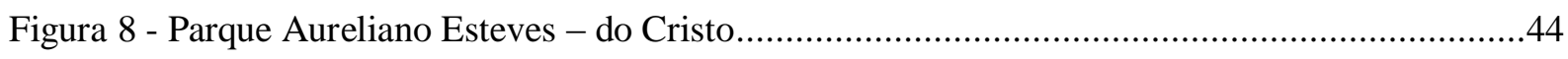

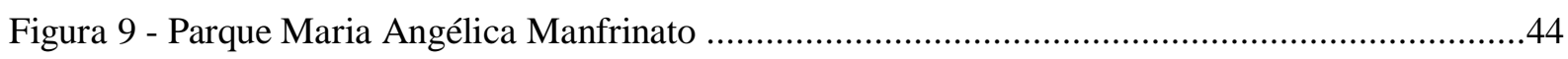

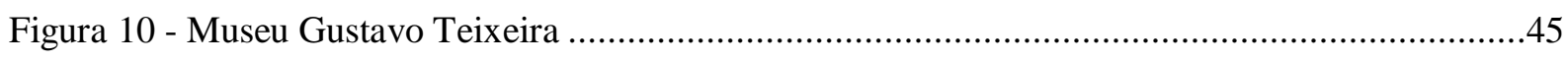

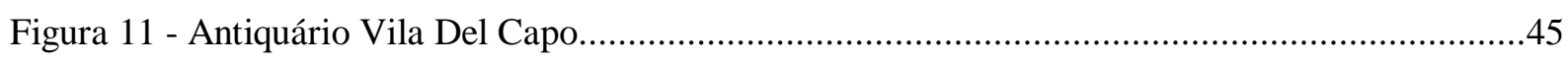

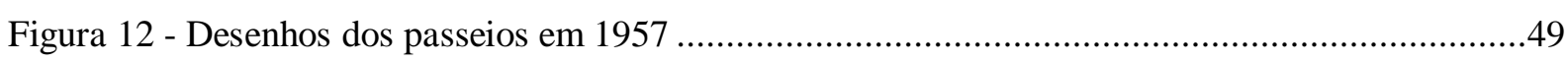

Figura 13 - Poeta Gustavo Teixeira no Jardim Público 1920 ...........................................................50

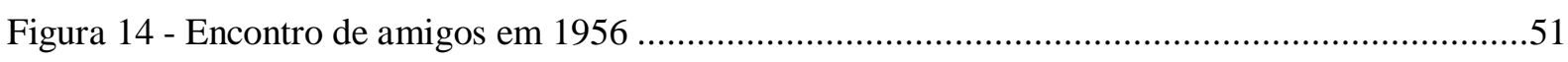

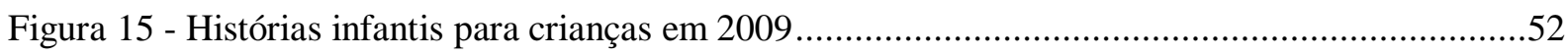

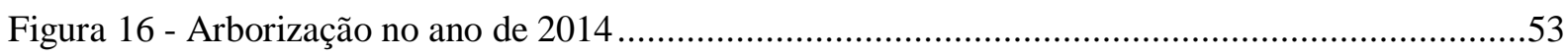

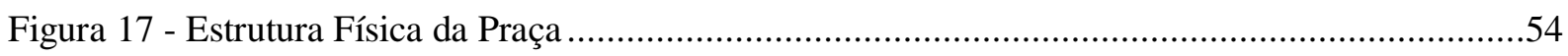

Figura 18 - Localização Praça em relação à Rua Malaquias Guerra....................................................55

Figura 19 - Localização Praça em relação à Rua Joaquim Teixeira de Toledo ...................................55

Figura 20 - Localização Praça em relação à Rua José Estanislau de Oliveira........................................56

Figura 21 - Localização Praça em relação à Rua Veríssimo Prado .....................................................56

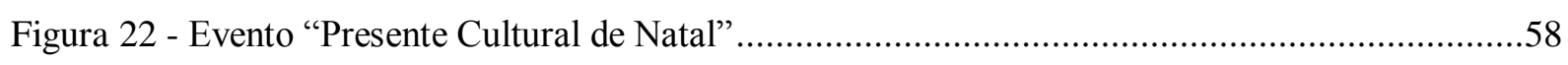

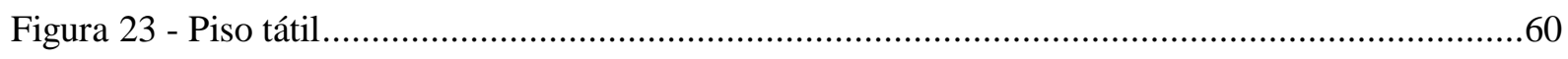

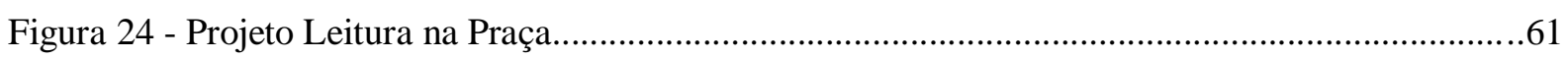

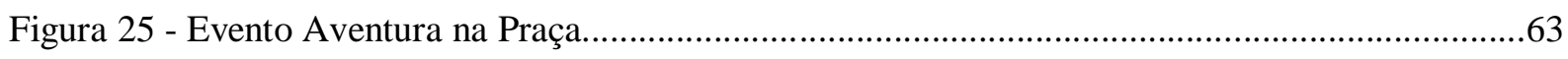

Figura 26 - Apresentação Teatral - Circuito de Artes Sesc 2016........................................................64

Figura 27 - Semana Literária Gustavo Teixeira - 2016................................................................65

Figura 28 - Atividade Contação de Histórias - 2015......................................................................66

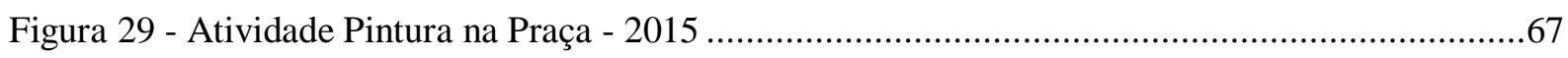

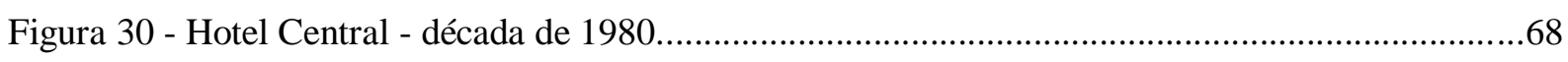

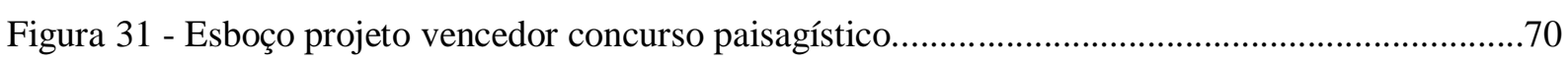

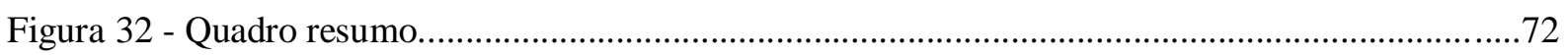




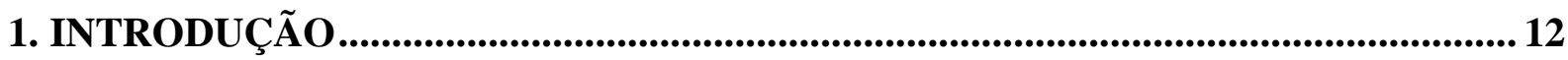

2. HOSPITALIDADE E SUAS DIMENSÕES ..................................................................... 15

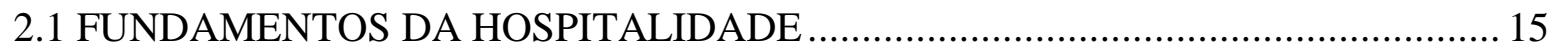

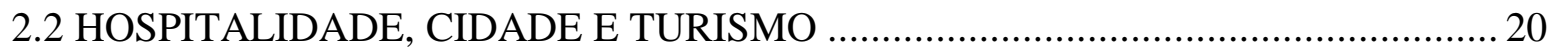

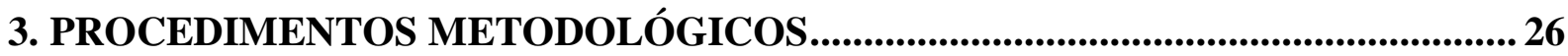

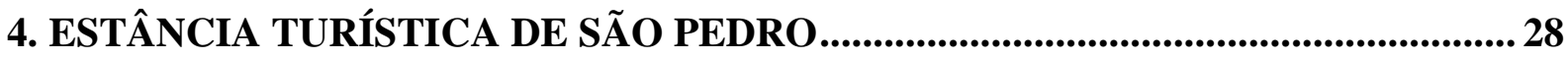

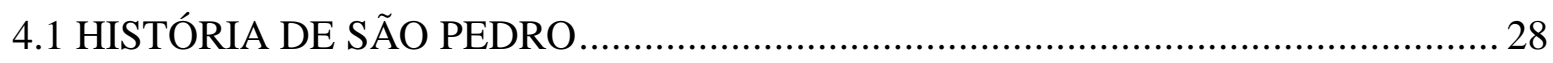

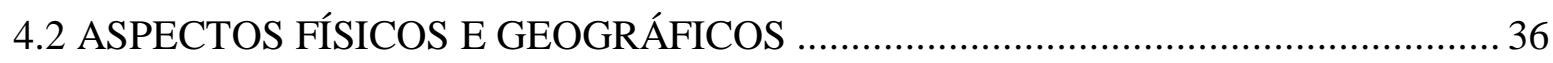

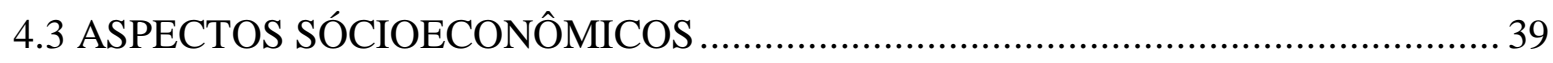

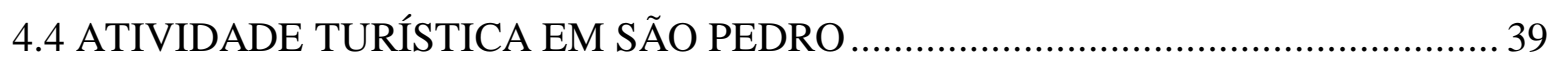

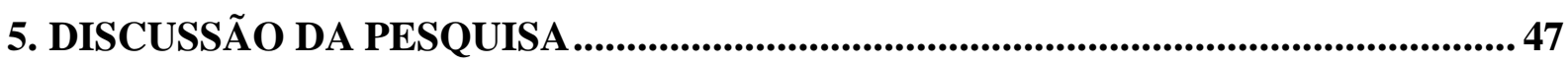

5.1 ESPAÇOS PÚBLICOS E MOBILIÁRIOS URBANOS NA HOSPITALIDADE..........47

5.2 DE JARDIM PÚBLICO À PRAÇA GUSTAVO TEIXEIRA........................................ 47

5.3 PERFIL DOS ENTREVISTADOS - ANÁLISE E DISCUSSÃO ………………….....57

6. CONSIDERAÇÕES FINAIS .............................................................................................74

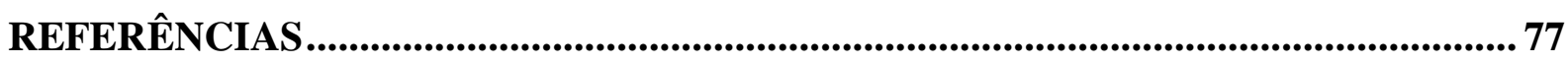

APÊNDICE A - ROTEIRO DE ENTREVISTA ANFITRIÃO ….....................................82

APÊNDICE B - ROTEIRO DE ENTREVISTA VISITANTE .........................................83 


\section{INTRODUÇÃO}

O turismo nas últimas décadas se firmou como atividade terciária nas sociedades desenvolvidas, tornando-se, dessa forma, um fenômeno social, cultural e econômico. O turismo urbano, atividades desenvolvidas nos espaços das cidades, ganha força nesse contexto e o movimento de produção e consumo urbano intensifica-se. Para Silva (2004, p. 53) a atividade do turismo, expressão da divisão entre trabalho e lazer, compreende "não só uma divisão de tempos como também de lugares". Isso implica dizer que existe clara relação entre a atividade turística e os destinos que recebem e desejam receber tal público e que gestores e planejadores públicos devem ter como um de seus focos de atenção o próprio destino turístico em si.

De uma forma quase que natural, a relação entre turismo e espaços se estabelece. Bens, imagens, signos e símbolos do turismo são disponibilizados e consumidos nos lugares considerados turísticos. Silva (2004) afirma que tudo pode ser de interesse do turista e elementos naturais, ruas, edificações transformam-se em objetos de consumo. O que é diferente para o outro poder ser objeto do olhar do turista (URRY, 1996).

Para Grinover (2009), a essência da hospitalidade passa pelo papel da cidade, pois relações de receptividade e integração entre moradores e visitantes acontecem nesse cenário. Elementos sociais, culturais, históricos, econômicos e ambientais tornam a cidade hospitaleira ao proporcionar a interação, o acolhimento e relações sociais entre morador e visitante. Ainda segundo Grinover (2007), o nível da hospitalidade em uma cidade pode ser analisado por meio de três dimensões: acessibilidade, legibilidade e identidade, tendo como base o tempo e o espaço.

Possibilidade de acesso aos cidadãos é um dos fundamentos da acessibilidade. Essa dimensão deve proporcionar não somente o acesso a atividades e serviços, mas ainda, estabelecer a igualdade de oportunidades aos usuários urbanos. A acessibilidade é segmentada em dois grupos: a) física, que é tangível; e b) virtual, que é intangível. A física ou tangível engloba sistema de transportes e infraestrutura viária e localização de espaços e; serviços urbanos (saneamento, educação, saúde, segurança, lazer, entre outros). Já a virtual ou intangível - refere-se à cultura, informação e lazer, tornando o papel da cidadania fator primordial para a aproximação e interação social entre habitantes (GRINOVER, 2007).

Sob essa perspectiva, o visitante deve se locomover, sem dificuldades; encontrar o que busca, em um tempo considerável; ser acolhido e bem tratado, além de ter a ordenação urbanística a favor de seu acolhimento. Essa acessibilidade define-se com base em questões 
que vão além do geográfico, questões que abordem o socioeconômico e a capacidade de cada equipamento urbano a ser utilizado (GRINOVER, 2007).

A leitura de uma cidade feita por seus habitantes, visual e significativamente, define a legibilidade. Aspectos modernistas, históricos, geográficos, ambientais, culturais, entre outros, identificam a cidade por meio da legibilidade (MORENO, 2002).

Ao considerar a legibilidade como a organização de lugares públicos e ordenamento da paisagem, observam-se constantes intervenções no cenário urbano, tais como leis de zoneamento que possuem como objetivo a coordenação e o planejamento de regiões em favor de melhorias. Porém, o que se verifica, na maior parte das vezes, é o não cumprimento desse planejamento, ocasionando desordens no conjunto urbano.

A identidade da cidade é representada por um conjunto de fatores como história, aspectos arquitetônicos, costumes - que remetem a momentos familiares. Essa identidade traz o sentimento de pertencimento dessa estrutura urbana (YÁZIGI, 2001).

O pertencer, por sua vez, remete ao domínio, segurança, partilha de uma identidade de território. Esse pertencimento faz parte de uma das dimensões da hospitalidade quando associado ao acolhimento de imigrantes, a comensalidade à mesa, a aproximação da natureza (MONTANDON, 2004).

Para Grinover (2007) a identidade é móvel, está em transformação constante, porém sempre ligada à suas origens. "A única possibilidade de construir a hospitalidade pressupõe a capacidade de conhecer a cidade como ela é, sobretudo, de reconhecê-la como realidade" (GRINOVER, 2007, p 31).

A partir de considerações, esse estudo teve como problemática compreender como a hospitalidade pública se manifesta na cidade de São Pedro (SP), mais precisamente na Praça Gustavo Teixeira. Essa é a principal praça da cidade e está localizada em ponto central do município, com grande aglomeração de turistas. Praticamente todos os turistas que desfrutam a área urbana de São Pedro usufruem deste espaço. Neste sentido, a compreensão da hospitalidade pública nesta praça é também, de alguma forma, a compreensão da hospitalidade na cidade de São Pedro.

As questões norteadoras consideradas durante a reflexão acerca do tema foram:

1. Existe relação entre anfitrião e visitante?

2. A Hospitalidade pública, por meio de suas dimensões, se faz presente no local do estudo?

3. A acessibilidade torna perceptível ao anfitrião e visitante a informação, sinalização, transporte, acesso e acessibilidade? 
4. A legibilidade mostra a praça enquanto espaço público, dotado de infraestrutura, convertido a atrativo turístico, espaço para lazer e espaço verde?

5. A identidade evidencia os itens que compõem a história local, manifestações que resgatam a cultura e comércio do entorno com características históricas (bordado, artesanato, ponto cruz, museu, gastronomia - jaracatiá)?

6. Ações sociais, que interferem no dia a dia da cidade, são desenvolvidas?

O estudo teve por objetivo geral identificar e analisar como a hospitalidade pública se manifesta na Praça Gustavo Teixeira, em São Pedro, Estado de São Paulo, a partir da observação das relações entre moradores e turistas ou visitantes, tendo como base as dimensões de acessibilidade, a legibilidade e a identidade.

Os objetivos específicos, por sua vez, desdobraram-se em contextualizar historicamente o município e apresentar os pressupostos teóricos da hospitalidade que serão utilizados no trabalho; identificar e analisar as dimensões da acessibilidade, legibilidade e identidade a partir da relação entre morador e turista/visitante;

O primeiro capítulo refere-se à introdução da pesquisa. Conceituações acerca da hospitalidade, contextualização com a atividade turística, tema, problemática, objetivos e questões norteadoras são abordados.

O segundo capítulo, revisão bibliográfica, trata das definições de hospitalidade e suas dimensões estando dividido em dois itens. No primeiro traz-se autores como Camargo (2005; 2008; 2015); Grinover (2002; 2007; 2016); Montandon (2004); Lashley (2004) em discussões acerca das dimensões da hospitalidade. Enquanto no segundo aborda-se hospitalidade, cidade e turismo, discute cenários e atores envolvidos na prática da hospitalidade pública, além de suas dimensões.

O terceiro capítulo aborda os procedimentos metodológicos utilizados para o desenvolvimento do trabalho, apontando o método e as técnicas de coleta de dados para a pesquisa de campo e o perfil dos entrevistados.

O quarto capítulo apresenta a Estância Turística a ser estudada, expondo o contexto histórico, geográfico e econômico, além do desenvolvimento turístico.

O quinto capítulo traz um estudo mais detalhado sobre o local da pesquisa e aborda os dados coletados a partir de pesquisas, entrevistas e observações in loco. Análises e interpretações sobre a hospitalidade pública são levantadas.

O sexto capítulo, por fim, traz considerações finais embasadas nos objetivos iniciais. A discussão reforça a importância de hospitalidade nas relações humanas do destino turístico. 


\section{HOSPITALIDADE E SUAS DIMENSÕES}

\subsection{FUNDAMENTOS DA HOSPITALIDADE}

Ao longo dos anos, a hospitalidade tem apresentado diferentes significados e abordagens partindo do ponto de vista conceitual e cognitivo, chegando ao entendimento atual acerca de sua manifestação na vida humana, suas trocas e relações, em diferentes tempos e espaços (CAMARGO, 2005a; 2005b; 2015).

Por outro lado, do ponto de vista histórico, o ato da hospitalidade se relaciona a tempos remotos, surgindo no período pré-histórico mais especificamente antes de 8.000 a.C. Segundo Camargo (2005a), neste período já se encontravam sinais da hospitalidade no meio social humano em função da motivação de migração dos habitantes da terra. Tais indivíduos moviam-se não somente para encontrar novas terras como também para conhecer outros de sua própria espécie. Conforme descrito pelo autor, foi nesse período que:

[...] a então reduzida população da terra (sic), não superior ao milhão de pessoas, já espalhada em pequenos grupos por todo o espaço do planeta hoje habitado, era marcada pela intensa expectativa de encontrar, receber e conhecer outros seres humanos, o que ao deixar de povoar o pequeno universo sociológico então existente, passou a se chamar hospitalidade (CAMARGO, 2005a, p. 713).

Diante da necessidade de buscar abrigo e repouso, Barretto (1995) também defende a presença da hospitalidade nos períodos pré-históricos, tendo como argumento os deslocamentos migratórios e referenciando especialmente as longas viagens realizadas pelos povos nesse período.

De acordo com Grinover, (2002) o termo hospitalidade, tal como conhecido nos dias de hoje, teria surgido somente na Europa do século XIII. A origem mais provável estaria relacionada à palavra latina hospitalis que possui relação com acomodação ou acolhimento gratuitos, tal como a atitude caridosa oferecida aos indigentes e viajantes recebidos em conventos, hospícios e hospitais.

Segundo Walker (2002), por volta de 1.700 a.C., era possível observar menções à hospitalidade na Grécia e em Roma, sobretudo com o uso do termo em latim hospitalita-atis. Essas menções faziam referência ao ato de ofertar bom tratamento para aqueles que davam ou recebiam hospedagem, assim como hospes-itus referia-se àqueles que recebiam hospedagem especificamente, ou seja, o hóspede. 
O surgimento dos diferentes "locais de hospitalidade" deu-se apenas no período da Baixa Idade Média, entre os séculos XI e XV. Neste período distinguiam-se hospitais (hospitale-icum), hotel (hostel) e hospício (hospitium), por exemplo, sendo hospital e hospício locais especialmente destinados ao abrigo de peregrinos, oferecendo assistência variada e assistência medicinal em geral (GRINOVER, 2002; WALKER, 2002).

A hospitalidade também tem sua origem defendida na antiguidade como uma prática sagrada. Apresentava-se uma estreita ligação com a religião e cristianismo, pois havia a possibilidade de o hóspede ser Deus, sendo os forasteiros recebidos com alimento, calor e acomodação incondicionalmente. O dever e direito sagrado do acolhimento mostrava-se como pilar das relações no mundo cristão e justificava a incumbência direta de conventos, mosteiros e hospitais, estes também administrados pela Igreja, na recepção e assistência aos peregrinos e moribundos (GRINOVER, 2007; MONTANDON, 2004).

O estudo da hospitalidade, por sua vez, tem se dedicado a compreender e refletir sobre seu significado nas relações humanas. Tais relações têm sofrido mudanças em suas práticas conforme a sociedade também transforma seus valores morais, éticos, culturais e etc. Diversos são os estudiosos e pesquisadores que passaram a se dedicar ao tema a partir de diferentes referenciais e perspectivas acadêmicas. Esses esforços buscam adequar sua definição à realidade vivenciada pela sociedade contemporânea e agregar valores e significados desencontrados nos processos de globalização e capitalização do mundo (PLENTZ, 2007).

Conflitos gerados nas relações entre os indivíduos também passaram a exercer influência na vida em sociedade. Para Camargo (2005a) as transformações nos modos de cultura e produção contribuíram para a afirmação do oposto da hospitalidade: a hostilidade. Essas transformações desenvolveram-se a partir da evolução dos pequenos grupos sociais até o desenvolvimento das cidades e do estilo de vida urbano. Nesse aspecto Camargo (2005a) faz menção a essa transição associando às transformações no modo de trabalho e contexto das relações em sociedade:

\footnotetext{
A explicação mais conhecida é a que permeia a quase-totalidade da obra marxiana: a assertiva do determinismo do meio de produção sobre o modelo de sociedade e sobre a cultura. Sem dúvida, tal assertiva tem aqui sua evidência plena: a passagem do sistema coleta / caça do paleolítico para o sistema agricultura / pecuária do neolítico traz consigo a divisão social perversa do trabalho, a exploração do homem e o conflito / luta de classes [...] com silos de cereais e rebanhos a defender, o homem passou a ser lobo do homem (CAMARGO, 2005a, p. 714).
}

A presença da hostilidade, enquanto oposto da hospitalidade, nas relações de disputa por espaço contribuíram para destacar a relevância do tema na contemporaneidade, em 
especial na constante necessidade de acolhimento do desconhecido por meio do rompimento de barreiras cada vez mais rígidas (CAMARGO, 2015; LYNCH et al., 2011; SPOLON et al., 2015).

Enquanto campo de estudos acadêmicos, a hospitalidade traz em si conceitos e teorias específicas. Para Camargo (2005b, p. 52) a hospitalidade pode ser definida como "[...] o ato humano, exercido em contexto doméstico, público e profissional, de recepcionar, hospedar, alimentar e entreter pessoas temporariamente deslocadas de seu habitat natural".

Por outro lado, diversos autores possuem uma visão mais direcionada acerca da definição de hospitalidade enquanto atividade comercial. Entende-se, dessa maneira, a hospitalidade como uma prática econômica que visa a oferta de acomodação e/ou alimentação mediante a troca estritamente monetária. Na visão de Chon e Sparrowe (2003):

\footnotetext{
A indústria da hospitalidade compreende uma grande variedade de negócios, todos dedicados a prestar serviços a pessoas que estão longe de suas casas. Hoje, como no passado, os principais componentes da indústria são aqueles que satisfazem a necessidade de abrigo e acomodação e aqueles que fornecem alimentos e bebidas a seus clientes (CHON; SPARROWE, 2003, p.3).
}

Camargo (2005), diante das diferentes visões conceituais, considera a existência de duas vertentes de estudos que originaram as pesquisas sobre hospitalidade:

a) Escola Francesa: fundamenta-se nos conceitos de hospitalidade pública e doméstica, baseadas nos princípios de "ir e vir" e "dar-receber-retribuir". Teóricos franceses, ligados diretamente aos centros de pesquisas da Universidade de Paris, estão vinculados a essa escola. Para os sociólogos Anne Gotman e Alain Caillé a hospitalidade é "um conjunto de leis não escritas que regulam o ritual social e cuja observância não se limita aos usos e costumes das sociedades ditas arcaicas ou primitivas" (CAMARGO, 2005b, p.17-18);

b) Escola Americana: hospitalidade interpretada como fenômeno fundamentalmente comercial. Relação embasada em um contrato estabelecido entre hóspede e anfitrião. Essa relação, empresa-cliente, fundamenta-se nos princípios de normas, legislações e regimentos (CAMARGO, 2005b).

Diante aos diferentes olhares acerca das definições de hospitalidade, um conjunto de autores se reuniu na obra "Em busca da Hospitalidade", organizada por Lashley e Morrisson 
(2004). Lashley e Morrison (2004) trazem a proposta de criação de três domínios específicos, não restritos entre si, denominados de privado, social e comercial.

A relação entre esses domínios é ilustrada pelo diagrama de Venn (Figura 20).

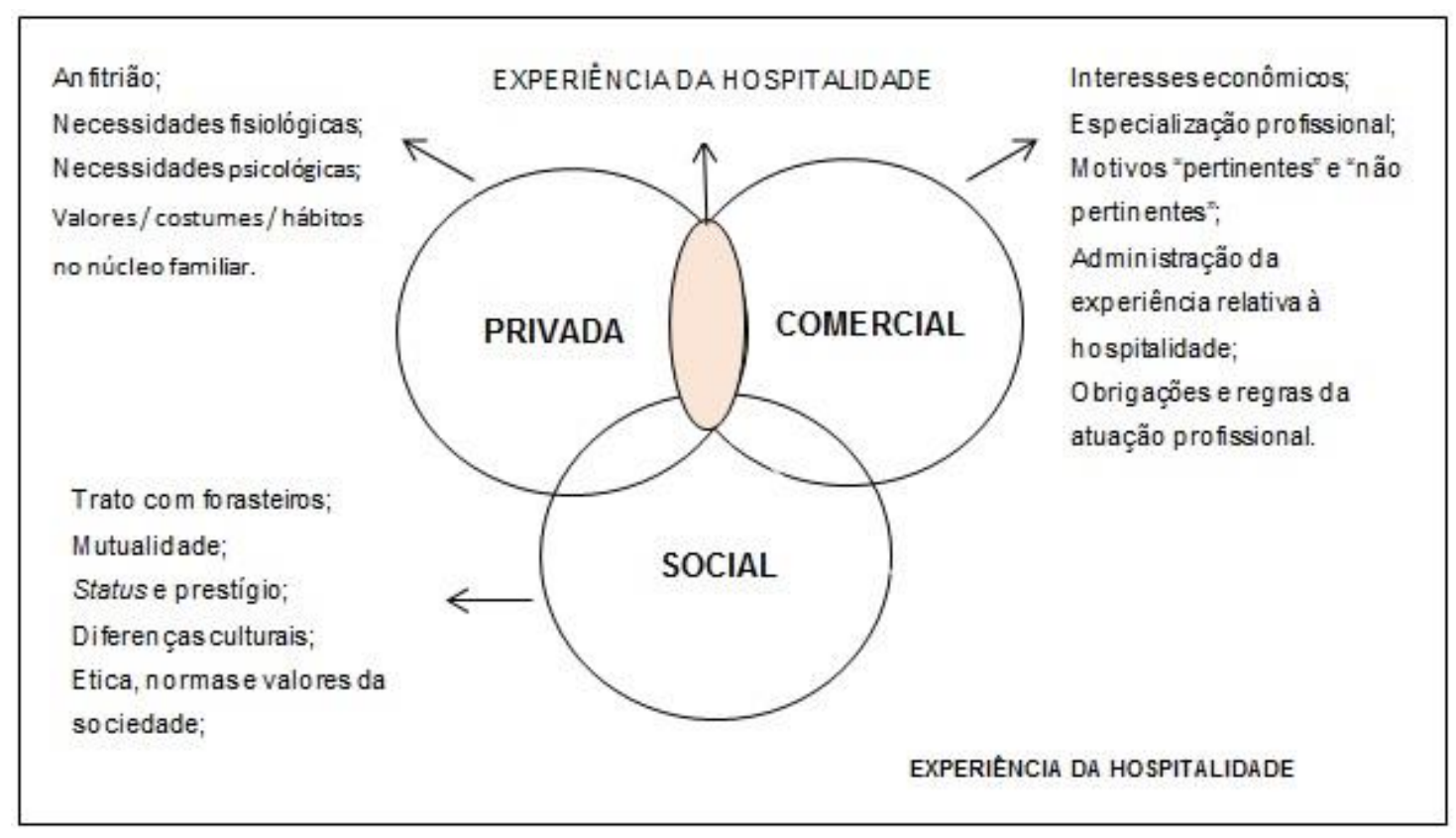

Figura 1 - Domínios da Hospitalidade

Fonte: Adaptado pela autora, com base em Lashley e Morrison (2004)

Para Camargo (2005b), esses domínios partem da existência de duas categorias de variáveis: tempos da hospitalidade - momentos nos quais se exercem as práticas sociais, e espaços da hospitalidade - ambientes nos quais a prática social acontece, considerando, além dos mencionados por Lashley e Morrisson (2004), um novo domínio baseado no ambiente virtual. Ao cruzar tempos e espaços, foram criadas 16 diferentes categorias. Suas bases são fundamentadas nos tempos de receber, hospedar, alimentar e entreter; e nos espaços: doméstico ou privado; público ou social; comercial e virtual.

A definição dos domínios da hospitalidade justifica-se pela necessidade de delinear possíveis abordagens no campo de estudo, tal como os conceitos de Camargo (2005b) e Lashley e Morrison (2004).

Hospitalidade doméstica ou privada é a praticada dentro do ambiente familiar, relacionada aos ensinamentos e intimidade pessoal, assim como o desenvolvimento de seu caráter e visão sobre o ambiente social e profissional. Segundo Lashley e Morrisson (2004, p. 14-15), o núcleo familiar:

[...] introduz os indivíduos em regras, rituais, normas e costumes que modelam as atividades de hospitalidade no cenário social (...) a recepção de hóspedes em ambientes domésticos proporciona a oportunidade de situar o indivíduo e a família 
no contexto da "civilidade" (...), portanto, desempenha papéis importantes na vinculação de indivíduos e grupos.

O domínio privado relaciona a hospitalidade ao ambiente do "lar" na base da relação entre anfitrião e hóspede. Existe aprendizado social e interação, resultantes da convivência familiar. Godbout (1998) afirma que a essência da manifestação da dádiva está na família, esfera doméstica. $\mathrm{O}$ receber gera laços importantes entre anfitrião e hóspede, proporcionando o bem-estar em todos (LASHLEY e MORRISON, 2004).

O contexto hospitaleiro, nesse domínio, atribui grande valor ao cenário sociocultural, uma vez que características, cultura e particularidades de um povo são o reflexo da forma de receber e prestar serviço a visitantes.

Hospitalidade social ou pública relaciona-se com o ambiente público, exercendo influência sob os indivíduos no contexto coletivo. Baseia-se em uma matriz de crenças, valores e costumes. Nesse domínio, as interações e atritos culturais, ideológicos e pessoais ganham maior evidência. Trata-se do domínio de maior dimensão e complexidade em função das múltiplas variáveis envolvidas (antropológica, sociológica, cultural, etc.), além de englobar, em determinados momentos, os demais domínios concomitantemente.

A hospitalidade no domínio social é vista como ambiente social, construído a partir de forças sociais, necessidades, produção e consumo de acomodação, alimentos e bebidas e entretenimento para as mais diferentes culturas. Considera-se, a fim de traçar reais necessidades e grau de importância de relacionamentos sociais de diferentes status, a cultura, o povo e o período histórico (LASHLEY e MORRISON, 2004).

A oferta de alimentos, bebidas e acomodação, sob a contrapartida da troca monetária, refere-se a hospitalidade comercial (LASHLEY e MORRISSON, 2004). A ligação entre a oferta, enquanto atividade econômica, e a hospitalidade define o conceito do domínio comercial. O poder público e a iniciativa privada estão intimamente ligados. A hospitalidade é praticada para um fim comercial e não como ato de caridade. Baseia-se na oferta e na procura e tem como cenário a comercialização de serviços e produtos com base na troca monetária (CRUZ, 2002).

Apesar de ser um domínio usualmente regido por um contrato de serviço, Camargo (2005b) afirma que a hospitalidade extrapola os limites da obrigação comercial a partir do desenvolvimento das relações interpessoais.

Para Dencker (2004), a relação comercial é marcada pelo estabelecimento do custo benefício, com um caráter de eficiência. Torna-se válido ressalvar que, embora as práticas de 
mercado desgastem as relações pessoais, dificilmente é possível desvincular a hospitalidade da dádiva, pois o indivíduo possui emoções e estabelece laços constantemente.

Nesse aspecto, Lashley (2004) explica que o prazer e o desejo de acolher e agradar o próximo podem ser concebidos por razões "pertinentes" e "não-pertinentes". As razões "pertinentes" referem-se ao ato genuíno da hospitalidade - o acolhimento ocorre pelo simples prazer de acolher. Já as razões "não-pertinentes" relacionam-se com a tentativa de ganhar vantagem sobre as ações ditas hospitaleiras, aumentando assim o valor de troca.

Apesar da distinção em suas razões, Camargo (2015) afirma que, na verdade, os domínios da hospitalidade não comportam a sua prática cotidiana, apesar de intimamente conectados e inter-relacionados: [...] A hospitalidade acontece nas frestas da inospitalidade. [...] Os domínios da hospitalidade acontecem na realidade nos interstícios de um cotidiano e de uma história marcada pela inospitalidade quando não pela hostilidade (CAMARGO, 2015, p. 44-45).

O campo teórico da hospitalidade tem buscado desenvolver cada vez mais sua abordagem conceitual na tentativa de absorver os aspectos inerentes ao fenômeno em questão. Conforme o avanço e o desenvolvimento de novas pesquisas, os estudos da hospitalidade têm ganhado maior força e robustez e buscado enquadrar o máximo da realidade incorporada pelo tema.

\subsection{HOSPITALIDADE, CIDADE E TURISMO}

As contribuições para o estudo da hospitalidade trazem perspectivas de diferentes disciplinas. Áreas como sociologia, antropologia, filosofia, direito, mesmo sem dominar o estudo como hospitalidade, abordam o tema em diferentes cenários (SPOLON et al., 2015).

Como exemplo, pode-se citar a obra de Valene Smith (1989) que retrata as relações entre anfitriões e visitantes na comunidade esquimó. Smith (1989) não traz referências à hospitalidade enquanto campo teórico, uma vez que tal teoria viria a se estruturar anos após a publicação. Sua obra de maior evidência no turismo é "Anfitriões e Hóspedes: a antropologia do turismo" (Hosts and guests: the anthropology of tourism), organizado pela autora e publicado em 1977, com sua segunda edição datada em 1989.

O interesse de Smith pela investigação do fenômeno turístico se desenvolveu baseado nas ciências sociais. A problemática da atividade turística que adentrou os campos de pesquisa dos antropólogos tornou-se motivo de "incômodo" para muitos. Reflexões foram 
estruturadas por sociólogos do trabalho que reconheciam o papel cada vez mais significativo do lazer nas sociedades contemporâneas (SMITH, 1989).

Segundo Gotman (2008), a obra de Smith foi a fundadora dos estudos voltados à investigação dos impactos turísticos, reforçando a ideia de que, no processo turístico, a população receptora é a mais afetada e, portanto, o elemento mais frágil na relação de troca.

Outra obra de relevância para os estudos da hospitalidade intitula-se "Ensaio sobre a dádiva e o dom", do sociólogo e antropólogo francês do século XIX Marcel Mauss (2003). Pesquisas do autor inspiraram o pesquisador brasileiro Luiz Octávio de Lima Camargo na concepção de um dos primeiros arcabouços teóricos voltados de forma mais direcionada e específica para o estudo da hospitalidade (CAMARGO, 2005b): sociedades primitivas tinham suas relações sociais baseadas em três deveres essenciais: dar, receber e retribuir (MAUSS, 2003). A dádiva, nesse aspecto, tornou-se o principal elemento norteador para fundamentar as relações de troca entre os indivíduos.

Na perspectiva de Camargo (2005b) todo o contato humano gera uma relação inicial de troca que é fornecida por um indivíduo, recebida pelo outro e, posteriormente, retribuída. Mauss (2003), em seus estudos, mostra que essa troca de gentilezas ocorria por meio de presentes (visitas, comemorações, artesanatos, etc.), ofertados de maneira voluntária e que “obrigatoriamente” eram retribuídos. O indivíduo que não retribuísse a dádiva poderia não ser aceito em sua comunidade, funcionando como contratos sociais.

A relação de inferioridade de um indivíduo para outro é explicada pelo próprio sistema da dádiva, onde aquele que recebe está, em dadas circunstâncias, submisso àquele que é recebido. Essa "assimetria" é ainda mais perceptível em alguns cenários culturais e socioeconômicos que envolvem o processo turístico relatado nos textos de Smith. Além disso, a condição trabalho-lazer, respectivamente associada no papel do anfitrião (que trabalha) e hóspede (que desfruta do descanso e do lazer) é realidade implícita na hospitalidade contextualizada na prática turística.

Assim, Camargo (2008, p. 28) analisa que:

Diferentemente, porém, da hospitalidade doméstica, hóspedes e anfitriões mantêm uma grande distância social, os primeiros ostentando símbolos socialmente distintos enquanto os segundos tentam retirar o maior lucro possível da presença dos forasteiros. Desses textos ressaltam, também, a preocupação com a assimetria dos atores, mas é, sobretudo, com a assimetria gravada socialmente (ricos e cultos, de um lado, pobres e gananciosos de outro), e menos com as assimetrias resultantes do próprio processo de hospitalidade, no qual o anfitrião, mesmo pobre, está em situação superior à do forasteiro, mesmo rico e as sucessivas mudanças de posição na sequência de dons e contradons. 
Percebe-se, portanto, a ambiguidade nas relações de troca entre o turista e o autóctone, onde parte da comunidade permanece dedicada ao turismo aceitando-o em sua realidade, enquanto a outra parte reservar-se em seus rituais ou concilia ambas as práticas.

Assim, como parte de seus estudos, Smith (1989) mostrou que todos os esquimós se beneficiaram economicamente dos avanços e do desenvolvimento dos serviços aéreos, impulsionados pela atividade turística. Acesso à escola e à universidade, a serviços de informações climáticas, às novas oportunidades de emprego ligadas ao turismo e à exportação de salmão para fora do Ártico, com o advento dos transportes marítimos de carga, foram também realidades vividas pela comunidade.

De acordo com Gotman (1997), as variáveis como tempo e espaço propiciaram mudanças nos conceitos e nas práticas de hospitalidade, criando um distanciamento do aspecto incondicional. As relações estabelecidas por meio do encontro promovido pela hospitalidade não se restringem apenas a oferta de repouso e alimento, resultam, inúmeras vezes, na formação de um vínculo social - uma vez estabelecida a relação humana. Valores como solidariedade, caridade e fraternidade estão intrinsicamente ligados a essas relações (GOTMAN, 1997).

Segundo Derrida (1977), a hospitalidade condicional é uma visita por meio de convite entre o anfitrião e o estrangeiro, sustenta-se como hospitalidade de direito. A hospitalidade incondicional, por sua vez, se expressa quando acolho para além da minha capacidade, exposição à chegada daquele que vem. A hospitalidade absoluta exige que me abra ao meu próprio existir "chez moi" (minha casa) e que ofereça não somente ao estrangeiro, como ao anônimo, ao desconhecido, e que lhe dê lugar, que o deixe vir, sem lhe pedir reciprocidade.

A lei da hospitalidade incondicional manda acolher incondicionalmente "a hospitalidade pura e incondicional, a própria hospitalidade abre-se, está antecipadamente aberta a quem não é nem esperado, nem convidado, a quem chegue como visitante, absolutamente estrangeiro, como chegante não identificável” (DERRIDA, 1977).

Laços sociais se consolidam em meio à convivência solidária e a cortesia, nos lugares de hospitalidade. Esses são, ainda, lugares de memória e identidade do patrimônio e potencializam a relação visitante anfitrião por meio do acolhimento. Para Grinover (2007) o urbano, enquanto área de convivência, necessita de ordenamento nos espaços coletivos e exige regras a partir dos princípios da hospitalidade. A formulação de políticas públicas voltadas para turismo e lazer demanda atenção da administração pública. 
Espaços públicos passam a ser organizados pela gestão pública para a convivência entre moradores e turistas, além de possibilitarem a criação de valores psicológicos e interrelações sociais.

\begin{abstract}
Ao perceber essa capacidade natural de atratividade (das cidades), alguns gestores públicos perceberam que uma cidade boa para se viver também é uma cidade boa para se visitar. E não o contrário. Ou seja, a preocupação passa a ser em primeiro lugar com o anfitrião - o ser que recebe - e em segundo lugar com o hóspede, ou como o turista - aquele que é recebido. Como consequência dessa percepção uma série de planos urbanos de longo prazo vêm sendo realizados desde o início do século XXI com a preocupação de inserir temas relacionados à qualidade de vida e ao bem-estar nas agendas das cidades brasileiras e estrangeiras (SEVERINI, 2014 p.87).
\end{abstract}

Camargo (2005) afirma que a hospitalidade, no setor público, engloba o "receber público", a "hospedagem pública", o "alimentar público" e o "entreter público". Questões urbanas estão profundamente ligadas dentro dessas quatro vertentes.

O hospedar público, com uma visão para além da hospitalidade hoteleira, refere-se às informações acerca da cidade, locais de transportes urbanos (terminais de ônibus, pontos de táxi). A gastronomia criada a partir da identidade da cidade está diretamente relacionada ao alimentar público. Equipamentos urbanos de lazer e eventos (parques, equipamentos de esportes, locais adequados para manifestações culturais), com o olhar mais voltado para o residente do que para os visitantes, referem-se ao entreter público (CAMARGO, 2005b).

Com o intuito de consolidar a hospitalidade social, o espaço físico, seja natural, artificial, rural ou urbano, é um componente essencial. Parques, praças, jardins, paisagens, além de infraestrutura básica, tornam a cidade mais ou menos hospitaleira. Desta forma, a qualidade do espaço é de extrema importância nesse processo (CASTELLI, 2005).

Para Camargo (2008, p.22) o sistema de dádiva no contexto urbano:

"O investimento estético - de qualquer natureza - em ruas, as praças, os monumentos e a sua infraestrutura de recepção e circulação, é uma manifestação regida pelo sistema da dádiva. A cidade se faz mais bonita e exibe sua beleza como dádiva aos que nela moram e aos que a visitam. Hospitalidade é um processo que envolve pessoas e espaços. A cidade se torna um espaço hospitaleiro para o ver-eser-visto das pessoas".

Grinover (2007), ao citar Alain Montandon, aborda a questão da infraestrutura e dos símbolos oferecidos pela urbe, sejam eles públicos ou privados, intensificarem a hospitalidade oferecida à população e ao visitante. De La Haba; Santamaría (2004, apud., Grinover, 2007), analisam a hospitalidade urbana com outro olhar: não há espaços hospitaleiros, mas locais em que há usos e ocupações hospitaleiras dos espaços. 
Desta maneira, para Grinover (2007), a existência da Hospitalidade em uma cidade pode ser avaliada a partir de três dimensões: a) acessibilidade; b) legibilidade e c) identidade, baseadas em medidas geográficas e temporais. Posteriormente, o autor inseriu mais três características: qualidade de vida, urbanidade e cidadania.

Possibilidade de acesso ao cidadão é um dos fundamentos da acessibilidade. Essa dimensão deve proporcionar não somente o acesso a atividades e serviços, mas estabelecer a igualdade de oportunidades aos usuários urbanos. A acessibilidade é segmentada em dois grupos: física, tangível, e virtual, intangível. A física - tangível - engloba sistema de transportes e infraestrutura viária e localização de espaços, serviços urbanos (saneamento, educação, saúde, segurança, lazer, entre outros). Já a virtual - intangível - refere-se a cultura, informação e lazer, tornando o papel da cidadania fator primordial para a aproximação e interação social entre habitantes (GRINOVER, 2007). A dimensão da acessibilidade está intimamente ligada à qualidade de vida.

Sob essa perspectiva, o visitante deve se locomover sem dificuldades; encontrar o que busca em um tempo considerável; ser acolhido e bem tratado, além de ter a ordenação urbanística a favor de seu acolhimento. Essa acessibilidade necessita ser definida com base em questões que vão além do geográfico, questões que abordem o socioeconômico e a capacidade de cada equipamento urbano a ser utilizado (GRINOVER, 2007).

A leitura de uma cidade feita por seus habitantes, visual e significativamente, define a legibilidade. Aspectos modernistas, históricos, geográficos, ambientais, culturais, entre outros, identificam a cidade por meio da legibilidade (MORENO, 2002).

Ao considerar a legibilidade como a organização de lugares públicos e ordenamento da paisagem, observam-se constantes intervenções no cenário urbano - leis de zoneamento, que possuem como objetivo a coordenação e o planejamento de regiões em favor de melhorias.

A identidade da cidade é representada por um conjunto de fatores como história, aspectos arquitetônicos, costumes - que remetem a momentos familiares. Essa identidade traz o sentimento de pertencimento dessa estrutura urbana. (YÁZIGI, 2001). Montandon (2004) afirma que o pertencer remete a conhecimento, segurança, partilha de uma identidade de território. Esse pertencimento faz parte de uma das dimensões da hospitalidade quando associado ao acolhimento de imigrantes, a comensalidade à mesa, a aproximação da natureza.

O pertencimento é vital: 'despertencidos' e desapropriados de nossas raízes perambulamos por nossas cidades, sem mitos fortes que nos amarrem, nossas heranças se perderam e não temos o que colocar no lugar: somos seres desagregados 
e sem coesão. No entanto, o desejo de pertencer a uma cidade, a um grupo, a um espaço ou a uma 'tribo' tem impulsionado movimentos sociais e ações culturais (GRINOVER, 2006, p.35).

Para Grinover (2007, p. 150) a identidade é móvel, está em transformação constante, porém sempre ligada a suas origens: “[...] A única possibilidade de construir a hospitalidade pressupõe a capacidade de conhecer a cidade como ela é, sobretudo, de reconhecê-la como realidade".

Na evolução de seus conceitos, Grinover (2016) mostra que a dimensão da cidadania se expressa na hospitalidade urbana, por meio do direito do cidadão de ir e vir, à liberdade, à participação nas decisões do município. Cidadania é poder exercer seus direitos civis. Desigualdade social, hostilidade, exclusão são características de cidades que impedem a cidadania plena.

Considerada resumidamente como o agrupamento das características citadas anteriormente, "urbanidade refere-se a como os espaços da cidade acolhem as pessoas (...) É o conjunto de qualidades boas e más que distinguem a cidade" (GRINOVER, 2016, p. 107). Urbanidade associa-se, ainda, a cortesia e civilidade das pessoas; aquele que é educado e cortês é um indivíduo dotado de urbanidade.

Bell (2007) analisa a dinâmica da hospitalidade urbana sob o olhar da influência de espaços comerciais e da comensalidade no bairro. Espaços comerciais como bares, restaurantes ou café acolhedores, com equipe engajada, estimulam o convívio entre as pessoas por meio de comensalidade, solidariedade e espírito de pertencimento.

Durante a ressignificação de uma área pública, os espaços comerciais podem possuir aspectos de urbanidade, legibilidade, identidade e manifestação da dádiva. A análise de Bell (2007) complementa as análises realizadas acerca da hospitalidade pública.

Os conceitos e as definições dos autores citados anteriormente, acerca de Hospitalidade Pública e suas dimensões, serviram como base no decorrer da pesquisa realizada na Praça Gustavo Teixeira. 


\section{PROCEDIMENTOS METODOLÓGICOS}

Em procedimentos metodológicos a pesquisa foi embasada na combinação de pesquisa documental e bibliográfica.

No que tange a pesquisa documental, as fontes escritas primárias são documentos de arquivos públicos; as secundárias referem-se a relatórios de pesquisas baseados em trabalho de campo de auxiliares, além de outras fontes primárias como fotografias e mapas. As fontes dos documentos são arquivos públicos municipais e arquivos particulares coletados em domicílios.

Parte dos documentos municipais consultados está arquivada no Museu Gustavo Teixeira. Trata-se de uma sala física na qual os documentos só podem ser acessados com auxílio de um colaborador e com instrumentos específicos como luvas.

Já os arquivos particulares foram consultados na residência de historiadores e professores da rede municipal de ensino, pois longas foram as conversas e os relatos coletados durante a consulta.

A pesquisa bibliográfica se embasou em autores como Bastos (2008), Bell (2007), Camargo (2006, 2008, 2015), Dencker (2004), Grinover (2007, 2009, 2013, 2016), Lashley e Morrison (2004), Mauss (2003), Montandon (2004), Panosso Netto (2011), Smith (1989), Wada (2012), entre outros, por meio de livros, artigos científicos, dissertações e teses. A escolha de tais autores foi fundamentada no decorrer das disciplinas cursadas, na bibliografia indicada pelos docentes e nas discussões levantadas pelo grupo de estudos.

Marconi e Lakatos (2003) afirmam que a bibliografia pertinente oferece meios para definir e resolver, não somente problemas já diagnosticados, como também explorar novas áreas onde os problemas não se enraizaram. Tal bibliografia proporciona o exame de um tema sob novo enfoque.

Dentre as técnicas utilizadas na pesquisa de campo estavam observação e pesquisa com dois grupos: anfitriões e visitantes no local delimitado pelo estudo. O anfitrião foi analisado sob os enfoques econômicos e de lazer e o visitante, por sua vez, sob o enfoque de lazer.

A observação possui como objetivo levantar informações e utiliza os sentidos na obtenção de determinados aspectos da realidade. Esta técnica identifica e obtém provas a respeito dos objetivos sobre os quais os indivíduos não têm consciência. Na observação sistemática, o observador sabe o que procura e pondera o que tem mais importância em determinada situação; deve ser objetivo, reconhecer possíveis erros e eliminar sua influência 
sobre o que vê (MARCONI e LAKATOS, 2003). Dentro dessa tipologia de observação, a pesquisadora não foi participante, pois possui envolvimento pessoal e profissional com o objeto de estudo (KAUARK, MANHÃES e MEDEIROS, 2010). Levantamento de cenas hospitaleiras, por meio de registros fotográficos, foi inserido no decorrer das pontuações.

A pesquisa de caráter qualitativo, por sua vez, é a obtenção de informações a partir do encontro entre duas pessoas, a respeito de um determinado assunto. Trata-se ainda de uma conversa face a face e é indicado como instrumento de trabalho nos diversos campos das ciências sociais. Esse estudo realizou uma pesquisa exploratória, o que permitiu indagações e levantamento de dados, bem como informações que não estavam contempladas no roteiro de pesquisa (KAUARK, MANHÃES e MEDEIROS, 2010).

Caracteriza-se também como pesquisa semiestruturada, pois a pesquisadora teve liberdade para desenvolver cada situação em qualquer direção, explorando amplamente a questão. As perguntas foram abertas, conforme roteiro de pesquisa citado no apêndice, e foram respondidas por meio de uma conversação informal. Dentre as modalidades cabíveis a essa técnica, optou-se pela entrevista focalizada. Essa modalidade possui um roteiro com tópicos relativos ao problema que se estudou, sondando razões e motivos e esclarecendo situações (MARCONI e LAKATOS, 2003).

A pesquisa foi aplicada nos meses de novembro e dezembro do ano de dois mil e dezessete e no mês de abril do ano de dois mil e dezoito, em diversos locais da cidade. Os moradores que colaboraram, anonimamente, foram escolhidos de acordo com o envolvimento que possuem com a praça: comercial; emocional; de lazer. Os turistas estavam usufruindo do espaço no momento da pesquisa, selecionando-se diferentes faixas etárias. 


\section{ESTÂNCIA TURÍSTICA DE SÃO PEDRO}

\subsection{HISTÓRIA DE SÃO PEDRO}

Na constante busca por alimento e riquezas, principalmente ouro, no Brasil colonial no início do século XVII, partiram da Capitania de São Paulo e de outras paragens paulistas os bandeirantes, adentrando o desconhecido sertão, a fim de desvendar o que o mesmo tinha a oferecer (SANTOS, 2009) $)^{1}$.

Nesse contexto, ocorreram as entradas sertão afora comandadas pelos chefes de tropas, que passaram a capturar e escravizar os índios para os trabalhos diários. Nessas entradas os bandeirantes serviram-se dos caminhos abertos nas matas pelos índios, na constante busca de metais e pedras preciosas. Afinal, "a descoberta de minas no Brasil, era insistentemente incentivada pela política colonial portuguesa" (SANTOS, 2009). Assim, em 1719 descobriuse ouro no morro do Rosário em Cuiabá.

Com os objetivos de se chegar a tal mina e escoar a produção até a Capitania de São Paulo, se fez necessário um caminho. Desse modo, em 1721, o governador da Capitania de São Paulo, Rodrigo Cezar de Menezes, ordenou aos moradores da capitania a abertura de um caminho pelo sertão a fim de chegar às novas minas de Cuiabá. Tal serviço era de reconhecimento real de Sua Majestade. "Como nenhum concorrente tivesse conseguido construir a estrada para as Minas de Ouro de Cuiabá, o sertanista Luís Pedroso de Barros se ofereceu" (DORIZOTTO, 2006), juntamente com seu bando, objetivando a absolvição de um crime.

Em 1723, com sua tropa, Luís Pedroso saiu em diligencia da vila de Itu. Com o intuito de abrir o caminho para as novas minas de ouro, Luís Pedroso permaneceu nove meses na mata. Partindo da Vila de Itu, seguiu o caminho do rio Capivari e deste ao rio Piracicaba. Passou pelas cabeceiras do rio Jacaré-Pepira, rompendo matas, campos e cerrados até o rio Grande (Paraná), dando conhecimento de seu sucesso ao governador da capitania (MANO, 2006).

O retorno de Luís Pedroso datou abril de 1724, porém com parte do caminho realizado. Em seu primeiro trajeto, utilizou o caminho aberto pelos bandeirantes, seguindo o traçado indígena. Ao sair das margens do rio Tietê, subiu o morro de Araraquara (Serra de São Pedro e de Itaqueri), mesmo a serra sendo um caminho íngreme e inviável.

\footnotetext{
${ }^{1}$ Poucos são os historiadores que relatam o desenvolvimento histórico do município. Dessa maneira, os autores utilizados são Santos (2009), Mano (2006), Chiarini (1970) e Dorizotto (2006).
} 
De acordo com o trabalho realizado por Dorizotto (2006) acerca do picadão de Luís Pedroso de Barros, depois de um período de descanso, o mesmo voltou ao trabalho da picada, buscando outra opção de caminho.

Nesta última tentativa caminhou mais para o norte, orientado pelo rio Corumbataí, subindo o espigão da margem direita (...). O picadão buscou o Porto de Recreio, caminhando entre as cabeceiras dos ribeirões Limoeiro e Caiapiá (...). No Porto Recreio atravessou o Corumbataí, subindo pela margem esquerda e depois de cruzá-lo novamente, margeou o seu afluente Passa-Cinco e bandeou para os lados de Itaqueri, atravessando os hoje municípios de Ipeúna e Itirapina, contornando a parte mais íngreme da Serra de São Pedro e do Itaqueri, buscando Brotas e os então já conhecidos saltos de Avanhandava e Itapura (DORIZOTTO, 2006).

Cabe salientar que ao chegar à região de Itirapina havia nesse mesmo caminho, uma entrada para as minas de Goiás. Em 1724 o caminho de Luís Pedroso estava quase finalizado, e em 1725 o caminho já estava pronto e seu novo trajeto aceito pelo governador D. Rodrigo César de Menezes, e sendo utilizado para o escoamento de bens de consumo e ouro da Capitania de São Paulo até Cuiabá e vice-versa.

Porém, em 1726, o caminho de Luís Pedroso é proibido por ordem de D. Rodrigo, por estar sendo utilizado para contrabando de ouro, não sendo pagos o imposto sobre o ouro no interposto. Pois este era circundado pelos sertanistas por outro caminho. Porém, nada impede que o mesmo, embora proibido, não tenha sido utilizado. Pois em 1730 há uma nova proibição.

Em 1770, Antônio Correia Barbosa, povoador de Piracicaba, conseguiu com o Governador da Capitania de São Paulo, D. Luís Antônio de Souza Botelho Mourão (Morgado de Matheus), a reabertura do caminho de Cuiabá, a partir de Piracicaba, pelos campos de Araraquara. Desse modo, Barbosa "não teve dificuldades para encontrar a estrada. A chamada Rota Abreviada dos Ituanos, para Cuiabá e Goiás era do conhecimento público e utilizada por índios, posseiros, caçadores, pescadores, contrabandistas e principalmente homens de negócio de Itu” (DORIZOTTO, 2006).

Nota-se assim, que o caminho aberto por Luís Pedroso de Barros, não passava pela cidade de São Pedro, e sim a contornava, todavia, no trajeto aberto havia várias ramificações, e uma delas adentrava as matas que posteriormente dariam lugar ao município.

Com o caminho aberto, no século XVIII, iniciam-se as concessões de sesmarias, ou seja, de uma gleba de terras, com a finalidade de povoar os campos de Araraquara, alargar a agricultura e mesmo o desbravamento de novas regiões auríferas. Esta região denominada de 
campos ou sertão de Araraquara compreendia a extensa região da margem direita do Rio Piracicaba até a cidade de Araraquara, passando pelas terras de São Pedro (SANTOS, 2009).

Em 1781, Antônio Francisco da Luz foi nomeado Guarda-mor das terras do Morro de Araraquara de Piracicaba e suas redondezas, pois contava-se que existiam minas de ouro nessas terras, além de um perigoso quilombo de negros fugidos, que roubavam todas as expedições que por ali passavam.

Os pedidos de sesmarias por essas paragens tiveram início a partir de 1780. Assim, é em 1782 que o Tenente Domingos Lima tem a confirmação de sua sesmaria nessa região, demarcada entre o rio Piracicaba e o Morro de Araraquara (Serra de São Pedro e do Itaqueri). As sesmarias eram concedidas a todos aqueles que a requeressem à Coroa Portuguesa, porém, era algo custoso e mesmo demorado, pois o requerente tinha que provar que possuía posses para desenvolver a terra e povoá-la. A partir de 1822 tais concessões sofreram diversas modificações. E, em 1850, com o advento da Lei das Terras, essas concessões foram extintas.

Antônio Correia Barbosa, o povoador de Piracicaba, em 1782, recebeu a concessão de uns campos de Piracicaba, "em um rincão que acompanha o rio Jacaré-Pepira e a serra de Araraquara, inteirando-se nas sobras das mais sesmarias que daqueles campos se tem tirado, contanto que não exceda da quantidade de três léguas" (L. 21, fls 149). Com o seguinte relato, trazido pelo aviso régio da concessão de terras, pode-se notar que a ocupação da região ia a franco progresso por estar às margens do caminho para Cuiabá (SANTOS, 2009).

Todavia, é a partir de 1810 que se intensificam os pedidos de sesmarias na região denominada sertões de Araraquara. Grande parte dos pedidos foi realizada por pessoas da região de Itu e de Piracicaba. Para a distribuição e demarcação das terras, os pontos de referência eram dados pelos rios Piracicaba, Jacaré-Pepira e os Morros de Araraquara. Assim, é possível através de uma minuciosa análise do Repertório das Sesmarias pertencentes ao Arquivo do Estado de São Paulo, agrupar o grande número de sesmarias concedidas nessa região.

Nesse sentido, a pesquisa mostra que a ocupação das terras, que décadas mais tarde dará lugar à cidade de São Pedro, remonta a um período de desbravamento dessa região entre os séculos XVII e XVIII.

A povoação da cidade de São Pedro teve início com o caminho oficial da Capitania de São Paulo até as minas de ouro de Cuiabá e Goiás aberto por Luís Pedroso de Barros, como já mencionado, para o escoamento da produção aurífera, assim como de gêneros de primeiras necessidades para a manutenção daqueles que emigraram para as zonas mineradoras (SANTOS, 2009). 
Nesse contexto surge a figura dos tropeiros, homens que conduziam tropas de gados, mercadorias, mensagens em lombo de muares nos tempos do Brasil Colônia. Assim, nos séculos XVII e XVIII, os tropeiros eram as figuras mais vistas e utilizadas dentro da colônia. Do sul do país arrebanhavam o gado e outros bens para a Capitania de São Paulo, comercializando partes desses gados na feira de Sorocaba. De São Paulo, outras comitivas caminhavam com suas mercadorias para Goiás e Cuiabá (SANTOS, 2009).

Como as viagens duravam dias, principalmente para os animais que necessitavam de pasto para se alimentar e descansar, existiam os "pousos" - locais de descanso e alimentação, tanto para os tropeiros quanto para os animais. Os donos de pousos não cobravam pelo pernoite, mas sim pelo pasto utilizado para a alimentação dos animais, pois os tropeiros carregavam consigo os ingredientes para a própria alimentação.

Nesses pontos de descanso para as tropas, ao mesmo tempo em que serviam de ponto de encontro para os tropeiros e seus animais, para descanso dos mesmos, estabeleceram diversos comércios com povoados, originando inúmeras vilas e cidades. Nessa conjuntura está associado o início da povoação de São Pedro (DORIZOTTO, 2006).

O rancho no caminho conhecido como picadão, formou-se por volta de 1807, próximo à vila de Piracicaba. Tal rancho era um pouso para tropeiros que utilizavam o caminho para chegar às minas de Cuiabá. O pouso pertencia a Floriano da Costa Pereira, conhecido por todos, naqueles tempos, como Florianão.

O lugar exato do pouso não se sabe ao certo, mas tudo leva a crer que estava localizado em um elevado de terras, entre os ribeirões Pinheiros e Samambaia. Possivelmente Florianão pode ter sido um dos primeiros sesmeiros a receber terras precisamente onde hoje se encontra o centro do município de São Pedro. Anos mais tarde, esse rancheiro doou um terreno dentro de suas terras para a construção da primeira capela, que de acordo com análises históricas localizava-se nas imediações da atual Igreja Matriz (MANO, 2006).

Os pousos não eram locais efêmeros, muito pelo contrário, eram pontos certos ao longo dos caminhos pelos quais as tropas passavam em comitiva. Com o passar dos tempos, esses pousos desenvolviam-se, ampliando os pastos e melhorando os ranchos.

São Pedro era nos primeiros tempos formado por matas que se derramavam pelas encostas da serra do Itaqueri e seus grotões, alongando pelas planícies e vales, acompanhando os cursos de águas. A zona, a que pertence atualmente o município de São Pedro, através do qual se penetrava no sertão, seguia o curso natural do Rio Piracicaba (MANO, 2006). 
A chegada da família Teixeira de Barros nesta localidade, está intimamente ligada a Revolução Liberal de 1842. Durante o Império havia duas dissidências políticas, os conservadores até então no poder, e os liberais que reivindicavam mudanças e lutavam por maior autonomia das províncias (SANTOS, 2009).

Em várias cidades e vilas do interior paulista houve apoio aos revoltosos, como as bases de Itu e Campinas. Liderados por Tobias de Aguiar mais de 1500 homens partiram em direção a capital paulista com a missão de depor o presidente da província, o Barão de Monte Alegre. Em consequência a esse movimento, outros motins ocorreram pela província de São Paulo. Porém, os revoltosos perderam o conflito, devido seu baixo poder de fogo frente aos inimigos do Império. A maior parte dos envolvidos foi condenada a prisão, e todos tiveram seus bens confiscados, além de sofrerem perseguições políticas.

Em 1844 o Imperador concede anistia a todos os envolvidos nos conflitos armados. Diante dessa deliberação imperial, a família Teixeira de Barros, que havia participado dos movimentos revolucionários a partir da cidade de Itu, principalmente seu chefe familiar Luís Teixeira de Barros, sofreu retaliações.

Absolvida dos crimes contra o Governo Regente, a família partiu da cidade de Itu em direção a uma sesmaria na região de Piracicaba, próxima ao morro de Araraquara, ao pé da serra de Itaqueri. Compraram as terras da antiga sesmaria do Pinheiro, uma vez que em 1844 não havia mais as concessões de terras por parte do governo (CHIARINI, 1970).

Ao chegarem na região, iniciaram aos trabalhos nas terras adquiridas, a abertura de caminhos e a divisão das terras entre os três irmãos Joaquim, José e Luís Teixeira de Barros para a fixação de seus descendentes na nova localidade.

Joaquim Teixeira de Barros, natural da cidade de Itu, nasceu a 14 de abril de 1793. Descendente direto de aristocrática família, neste pedaço de chão fincou raiz. Após se firmar na vida política, por sua iniciativa, decidiu construir a primeira Capela em 1856, que além de ser um ponto de fé dedicado a São Sebastião, por volta de 1850, também era referência de povoamento (SANTOS, 2009).

Aos poucos outras famílias oriundas de Itu começaram a chegar ao lugar como os Frota, os Galvão de França, os Góes Aranha, Barbosas, Morgados, dentre tantas outras. E foram se fixando nas fazendas, provenientes de antigas sesmarias concedidas na região. Com a abertura de novas propriedades intensificou-se a produção agrícola de subsistência e, consequentemente, um comércio entre as propriedades, muitas vezes a base de trocas (MANO, 2006). 
Em 1861 Antônio Teixeira de Escobar, filho de Joaquim Teixeira de Barros, enviou um pedido a Câmara Municipal de Piracicaba solicitando que o caminho conhecido como Picadão, pudesse servir de sacramento para os moradores do recente povoado. De acordo com Guerrini (1970), caminhos de sacramento, eram as pequenas estradas, ou picadas, que não passavam além do município, ou que ligavam bairros às cidades.

Tal pedido deve ser entendido como parte de um processo de formação de uma cidade ou mesmo de um bairro, pois em 1854 Piracicaba coordenava a Comarca, estando sob seu comando as Vilas de Rio Caro, Capivari, Limeira, Brotas e Araraquara.

Em 1864, pela Lei Provincial no 728 de 12 de abril, assinada pelo Presidente da Província de São Paulo, Dr. Francisco Ignácio Marcondes Homem de Mello, estava criada a freguesia de São Pedro, em território do município de Constituição (Piracicaba). Até então, São Pedro era conhecida como Capela do Picadão e, a partir de 1860, foi reconhecida como povoação com o nome de Capela de São Pedro, termo legal que reconhecia o povoado (SANTOS, 2009).

Pode-se notar que o povoado, designado freguesia, juntamente com a vinda de um pároco, começa a ganhar novos contornos. Começava a se estruturar com certa autonomia da Comarca de Piracicaba. Em janeiro de 1868, a povoação já se reunia junto a qualificação de votantes da vizinha comarca. Em 1869, a municipalidade de Piracicaba não possuía verba para manter um fiscal na freguesia de São Pedro, assim, o Sr. João José Pedroso, se ofereceu para realizar tal serviço de forma gratuita (CHIARINI, 1970).

No ano de 1874, os moradores da freguesia peticionaram uma agência dos Correios. Desse modo estavam lançadas as bases para a nova Vila de São Pedro, que já contava com mais de 5.000 pessoas, fato este que ocorreu em 1879.

Estando a vila em pleno desenvolvimento, principalmente na área econômica, advindo da produção agrícola, do plantio de cana-de-açúcar e do café, foi em 1881, mais precisamente pela Lei Provincial de 22 de fevereiro, que a então Vila de São Pedro foi elevada a Município, o que lhe garantia a independência da tutela de Piracicaba (MANO, 2006).

Dessa maneira, data de maio de 1882 o oficio para proceder-se na paróquia de São Pedro a eleição dos vereadores e juízes de paz a fim de governarem a cidade. Em 11 de fevereiro de 1883 houve a instalação e a posse dos membros da Primeira Câmara Municipal de São Pedro, sob a coordenação do Dr. Manuel de Moraes Barros, Presidente da Câmara Municipal de Piracicaba. Foi a partir da nomeação e posse da Primeira Câmara que se confirmou definitivamente a emancipação política e administrativa de São Pedro, iniciando-se assim, uma nova fase na história local (SANTOS, 2009). 
Iniciando os trabalhos, a eleição para presidente interino elegeu o Sr. Veríssimo Prado, por ser o mais idoso obreiro do município. Na sequência, Malachias Rogério de Salles Guerra Filho foi escolhido como secretário da câmara. Os juízes de paz foram Henrique Pinto da Silva, Francisco Torquato de Aguirra e Elias Galvão de França (MANO, 2006).

As eleições para vereadores ocorriam a cada três anos, elegendo apenas 06 representantes. Dentre os primeiros vereadores, eleitos somente pelos cafeicultores com mais de dois mil pés de café, eram votados o Presidente da Câmara, o Vice-Presidente e o Intendente, sendo este último o responsável por desempenhar as funções do poder executivo, pelo período de um ano (MANO, 2006).

O processo educacional inicia-se em São Pedro no ano de 1873, quando o primeiro professor de ensino infantil, Sr. Antônio Dias Ferraz Nápoles, auxilia na instalação da primeira escola pública subvencionada pelo governo da província (SANTOS, 2009).

Ao final de 1901, São Pedro contava com mais duas escolas, sob a regência dos professores normalistas Ambrosina Laudelina Bonilha de Toledo, responsável pela turma feminina, e Joaquim Norberto de Toledo, responsável pela turma masculina. Entre os anos de 1902 a 1910, foram criadas mais 05 escolas no município.

O Grupo Escolar São Pedro, um dos marcos na história educacional do município, foi inaugurado no ano de 1913. Em 1918, atividades ligadas a área agrícola foram inseridas no currículo, graças a doação do terreno contíguo ao pátio.

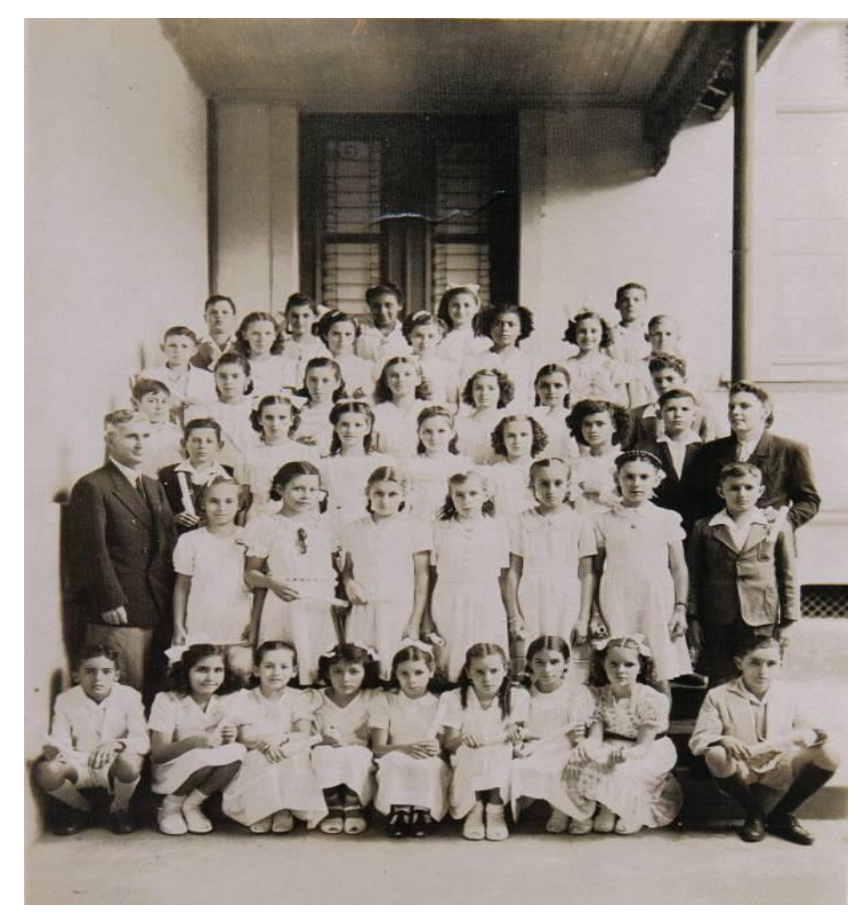

Figura 2 - Alunos do Grupo Escolar em atividade externa Fonte: Santos, 2009 
Nesse mesmo período, outras escolas foram fundadas: escolas das fazendas Santa Júlia, Santa Isabel, Serreta, Aurora e 13 de Maio; escolas dos bairros: Palmital, Graminha, Grama, Paiol de Telha, Londa, Boa Vista do Jacaré, Cardozos, Macucos, Baixadão, totalizando 650 alunos. No ano de 1936, esse numero se elevou para 934 estudantes.

Atualmente, a cidade conta com 21 escolas municipais, 04 escolas estaduais e 04 colégios particulares. A rede municipal atende mais de cinco mil crianças, divididas entre ensino fundamental, médio e supletivo. Jovens do município se deslocam para cidades vizinhas somente para o complemento do ensino superior presencial, uma vez que polos de universidades públicas e particulares oferecem alguns cursos de graduação a distância (SÃO PEDRO, 2013).

O sistema de saúde na cidade tem em sua história um início de colonização com médicos inexistentes na região. As dores, febres e doenças comuns dos enfermos locais eram tratadas com remédios caseiros, ensinados pelos mais velhos (SANTOS, 2009).

Por volta de 1870, Manoel Lemos, enfermeiro na Guerra do Paraguai, voltou para a vila e passou a ser procurado pelos adoentados como "curador". Atendia aos pedidos examinando os doentes das redondezas.

No ano de 1906, após um surto de conjuntivite na região, constava no orçamento do Estado, o valor de 1:500 contos de réis destinados a Conferência São Vicente de Paula, para a construção de uma Santa Casa de Misericórdia na cidade. Dessa forma, juntamente com um fundo da municipalidade para tal fim, foi adquirido um terreno e na sequência iniciou-se a construção da Santa Casa de Misericórdia (SANTOS, 2009).

Em 1908, com apenas quatro leito, a Santa Casa foi oficialmente instalada. Novas edificações foram construídas ao longo dos anos, pequenas cirurgias e gabinete dentários foram inaugurados. A modernização teve seu início no ano de 1979 com a aquisição do primeiro aparelho de Raio X.

Atualmente, o município conta com 15 estabelecimentos de saúde, dos quais 6 são de administração pública e 09 de administração privada (SÃO PEDRO, 2013).

Diversos pesquisadores datam a introdução da cultura cafeeira de forma mais eficaz no Brasil a partir de 1818, nas regiões de São Paulo e Rio de Janeiro. No oeste paulista, aos poucos as plantações de gêneros alimentícios e cana-de-açúcar cederam lugar as plantações de café. Seguindo os caminhos abertos pelo advento da ferrovia no oeste paulista, também se desenvolveu o alargamento das zonas cafeeiras (SANTOS, 2009).

No que tange as zonas cafeeiras paulistas, uma vez chegados os imigrantes em solo brasileiro, desembarcavam em Santos e seguiam de trem até São Paulo, onde se instalavam 
temporariamente. Aguardavam os fazendeiros que os conduziriam até suas fazendas para exercerem trabalhos regidos por um contrato familiar de produção assalariada.

No ano de 1887, inicia-se a entrada de imigrantes na cidade de São Pedro. Eram eles espanhóis, portugueses, mas em sua grande maioria, italianos. São Pedro despontava no oeste paulista como produtor de café de boa qualidade devido a seu ao clima e a qualidade da terra local. O auge da entrada de imigrantes, no município, ocorreu entre os anos de 1889 e 1895 (MANO, 2006).

Um dos propulsores do povoamento de São Pedro, Joaquim Teixeira de Barros, foi quem primeiro introduziu o cultivo do café, provavelmente nos idos de 1860-1870. A produção do café desencadeou o enriquecimento da elite rural local e o desenvolvimento econômico da cidade, no período áureo de sua produção entre 1890 a 1920 (MANO, 2006).

Em 1910 a população do município era de aproximadamente 10.000 habitantes, sendo 6.000 italianos, 3.000 brasileiros e 1.000 de outras nacionalidades. Desse modo, faz-se necessário atentar quantidade de italianos no município, e consequentemente, o legado que conferiram à população (SANTOS, 2009).

\subsection{ASPECTOS FÍSICOS E GEOGRÁFICOS}

O município de São Pedro, com sua população de 34.595 habitantes, localiza-se no centro do Estado de São Paulo e abrange uma área de $611,278 \mathrm{Km}^{2}$. Integra a microrregião de Piracicaba, estando à $100 \mathrm{~km}$ de Campinas, $30 \mathrm{~km}$ de Piracicaba e a $180 \mathrm{~km}$ da cidade de São Paulo (IBGE, 2016).

Em decorrência de sua localização, os municípios limítrofes são Itirapina, Torrinha, Brotas, Águas de São Pedro, Charqueada, Santa Maria da Serra e Piracicaba. Possui como principais distâncias Piracicaba com 29 km; São Manoel 80 km; Campinas, Botucatu e São Carlos 100 km; São Paulo 180 km; Bauru e Ribeirão Preto 200 km; Santos 280 km (IBGE, 2016). 


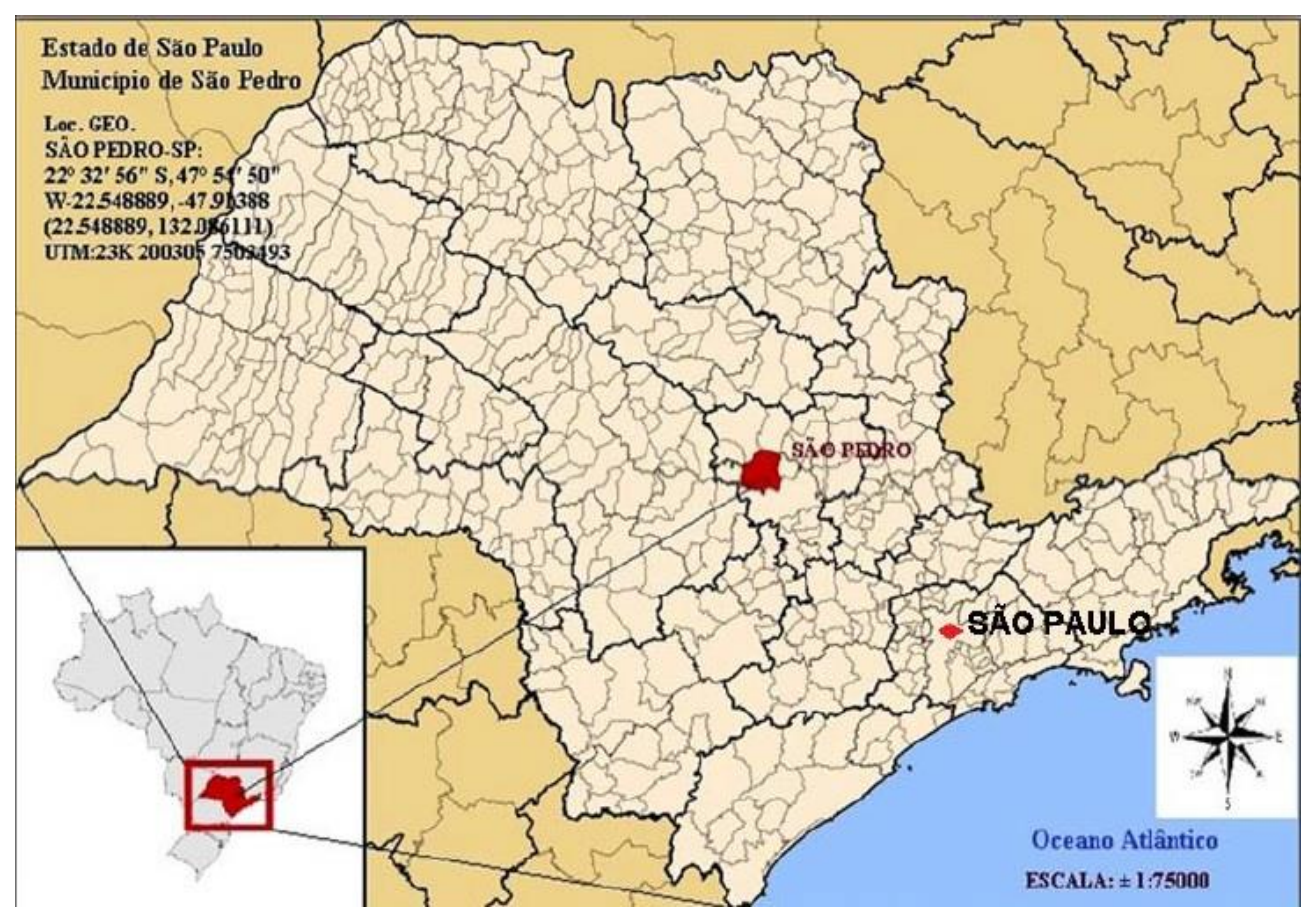

Figura 3 - Localização de São Pedro no Estado de São Paulo Fonte: São Pedro 2013

Sua topografia composta por zonas montanhosas, planícies e baixadas, permite uma altitude na área urbana de $580 \mathrm{~m}$ e $950 \mathrm{~m}$ no alto da serra. O relevo apresenta, em termos geomorfológicos, compartimentos referentes ao planalto ocidental constituído basicamente de rochas de formação areníticas. Os solos arenosos possuem grande susceptibilidade de ocorrência de erosão hídrica. As depressões periféricas constituem-se por arenitos e sílticoargiloso e, as cuestas basálticas são compostas por arenitos avermelhados e derrames de basalto (SÃO PEDRO, 2015).

A área do município apresenta resíduos de coberturas florestais como Mata Tropical Latifoliada, Mata Galeria, Vegetação Higrófita e Formações Campestres, com espécies de Campo Cerrado, conforme detalhado abaixo:

- Mata Tropical Latifoliada: encontrada em terrenos que constituem as frentes escarpadas da "Serra" de São Pedro, nos rebordos escarpados - parte norte do município e em boa parte da Depressão Periférica. Identifica-se esse tipo de vegetação pelas palmeiras “arencastrum romanzoffiana”, embaúba, jacarandá, peroba, cedros, cabreúvas, canelas e guarantans;

- Mata Galeria: encontrada junto às nascentes de água, em toda extensão do município mata ciliar. Árvores com diferentes portes e larguras variáveis, espécies como 
ingazeiros, figueiras, guaiembê, gauipe, taioba, samambaias e cipós representam a tipologia;

- Vegetação Higrófita: encontrada em quase todo o município, principalmente em áreas onde o solo encontra-se encharcado ou com difícil escoamento. Espécies como taboas, sangras e rabo-de-burro são características do local;

- Formações Campestres: originam-se na Depressão Periférica Paulista e no reverso da "Serra" de São Pedro. Espécies como agarra-agarra, unha-de-gato, ingazeiros, barbade-bode, guaxuma, capim gordura, indaiás, ipês amarelos, gabirobas e cambuís compões o cenário juntamente com vegetação formada por gramíneas e pequenas árvores ou arbustos, próprios de solos arenosos (SÃO PEDRO, 2015, p. 10).

O clima da Estância Turística de São Pedro é típico de zona climática transicional, apresentando conflitos de massas de ar oriundas do leste - Tropical Atlântica, noroeste Equatorial e Tropical Continental e, do sul ou Polares.

Os primeiros e últimos meses do ano caracterizam-se por um período chuvoso com excesso de água, enquanto que nos demais meses observa-se um período com estiagem absoluta, ou seja, o verão caracteriza-se quente e chuvoso e o inverno extremamente seco.

Chuva orográfica (precipitação em função da altitude) e temperaturas inferiores às encontradas na Depressão Periférica Paulista originam-se na área da cuesta de São Pedro. Nota-se, contudo, que as características climáticas gerais são mantidas (a cidade de São Pedro encontra-se a 550 metros de altitude, enquanto que o alto da "serra" apresenta variações de altitude entre 900 e 1000 metros). As temperaturas variam entre $42^{\circ} \mathrm{C}$ (máxima) e $0,3^{\circ} \mathrm{C}$ (mínima) (SÃO PEDRO, 2013).

Referindo-se a rede hidrográfica regional, essa possui como característica a densidade, uma vez que é constituída por diversas nascentes. Tais nascentes originam, inúmeras vezes, em cascatas e corredeiras ao longo do território municipal.

Os rios localizados no "front" da cuesta são afluentes, constantemente, do rio Piracicaba. Já os rios que nascem além do divisor de águas, situado a aproximadamente dois quilômetros do rebordo escarpado, tornam-se afluentes do rio Jacaré-Pepira Mirim.

Nos rios de baixa competência, os quais proporcionam a deposição de sedimentos provenientes das áreas mais altas, existe a exploração mineradora de areia para fundição de metais (SÃO PEDRO, 2015). 


\subsection{ASPECTOS SÓCIOECONÔMICOS}

A principal atividade econômica da Estância Turística, da sua fundação até meados de 1929, foi a cultura do café. Nesse mesmo ano a crise cafeeira se instaurou no país e, como alternativa econômica, o bordado foi introduzido na comunidade (SANTOS, 2009).

A partir da produção de 1940, São Pedro tornou-se nacionalmente conhecida devido a produção de bordados, concedendo-lhe o título de "Capital do Bordado". Tal título impulsionou a quantidade de visitantes de todo o país, uma vez que as viagens eram motivadas pelo turismo de compras.

Em meados da década de 1970, o bordado atingiu o seu ápice, decaindo na sequência, início da década de 1980. O cenário econômico da época fez com que o Poder Público buscasse alternativas para dar continuidade ao desenvolvimento turístico rentável. Além de desenvolver o produto turístico, o município passou a se preparar para a atividade agropecuária, substituta do café (SANTOS, 2009).

Diversas áreas onde o café era cultivado foram transformadas em pastos ou formatadas a fim de receber plantações de cana-de-açúcar, atividade de grande importância econômica para o Município até os dias de hoje. O plantio de cana ocupa em torno de treze mil hectares, produzindo anualmente 910.000 toneladas (SÃO PEDRO, 2013).

A segunda maior cultura do município é a de eucaliptos, seguida pela bovinocultura de corte e de leite. Pesquisas recentes apontam o setor de serviços em como a principal atividade econômica do município, seguida pelo setor industrial e setor agropecuário (SÃO PEDRO, 2013).

De acordo com a Fundação Sistema Estadual de Análise de Dados (SEAD), o Produto Interno Bruto da cidade totalizava em 2010, aproximadamente, um milhão de Reais, resultando em um Produto Interno Bruto "per capita", estimado, de treze mil Reais e renda "per capita" em setecentos Reais.

\subsection{ATIVIDADE TURÍSTICA EM SÃO PEDRO}

A região de São Pedro tem apresentado, por meio de sua história, relação com a atividade turística. Seu potencial começou a ser desenvolvido a partir da descoberta de águas medicinais, com alto teor de enxofre e bicarbonato, durante prospecções em busca de petróleo realizadas na década de 1930. 
A partir da implantação de balneários rudimentares, em 1932, o fluxo de turistas começou a se desenvolver, sobretudo, entre aqueles que buscavam a cura para seus problemas de saúde (SÃO PEDRO, 2015).

Anos depois, mais precisamente em 1934, empreendedores adquiriram as terras onde se encontravam as fontes hidrominerais e passaram a desenvolver o projeto de implantação de um polo turístico. Esse projeto tinha por objetivo desenvolver o turismo com implantação de balneários adequados e, complementando a estrutura, hotéis, restaurantes, cassinos e loteamento de terras circunvizinhas.

Com a inauguração do Grande Hotel São Pedro, em 1940, que abrigava em sua estrutura hospedagem e serviços de balneário, além de um luxuoso cassino, o turismo da região começou a apresentar sinais de estagnação (SANTOS, 2009).

Entre os anos de 1940 e 1948 a Estância Hidromineral de Águas de São Pedro era um loteamento da cidade de São Pedro, tendo como registro no Cartório de Registro de Imóveis os números um, dois, três e quatro. Em 1948, a Estância Hidromineral foi elevada à categoria de Município Autônomo, desmembrando-se da cidade de São Pedro.

$\mathrm{Na}$ década de 1950, as atividades turísticas se resumiam apenas àquelas ligadas aos objetivos terapêuticos e às férias para os indivíduos das classes sociais mais favorecidas. Essa estagnação justifica-se pela separação de Águas de São Pedro do município de São Pedro; pelo período de guerra e pelo fechamento de diversos cassinos.

A popularização das segundas residências, nas décadas de 1960 e 1970, impulsionou o turismo na região, novamente. Empreendedores divulgavam o produto em centros urbanos, originando, assim, a rápida proliferação de empreendimentos imobiliários.

Somada a esses fatores, a atividade da confecção de enxovais bordados a mão se desenvolveu na cidade de São Pedro e a procura por este produto cresceu, fato que, além incrementar a oferta turística regional, atraiu um público próprio. Nesse período a cidade era conhecida no Estado como "Capital do Bordado". O perfil desses turistas caracterizava-se pelas compras, ou seja, comerciantes revendiam estes bens em suas cidades de origem e consumidores finais buscavam determinados produtos com qualidade e melhores preços (SANTOS, 2009).

No ano de 1979, cidade foi elevada, pelo Governo do Estado, à categoria de Estância Turística de São Pedro em decorrência da movimentação turística ocasionada pelo bordado. Segundo a Secretaria de Turismo do Estado de São Paulo "Estâncias Turísticas são cidades com muitas tradições culturais, patrimônios históricos, artesanatos, lindas paisagens, centros de lazer, além de ótimos serviços de gastronomia” (SÃO PAULO, 2016). 
Em meados da década de 1980, devido a fatores econômicos decorrentes dos planos de desenvolvimento apresentados pelo governo federal, aliados à inexistência de um planejamento turístico, o turismo e a produção de bordados na Estância Turística de São Pedro declinaram. Consequente a esse cenário, a economia que tinha seus alicerces estruturados no consumidor de enxoval, passou a enfrentar dificuldades.

Nos dias de hoje, os meios de hospedagem totalizam 34 empreendimentos, entre hotéis, pousadas e SPA (SÃO PEDRO, 2015). A hospedagem é um somatório de bens e serviços que atendem às necessidades e preferências dos hóspedes. Este setor busca satisfazer as expectativas de acomodação das pessoas que por algum motivo estão fora de seus domicílios e por isso, necessitam de um local para se abrigar, algo que proporcione conforto e bem estar, independente do tipo de turismo que pratiquem.

Referindo-se a área gastronômica, a cidade possui aproximadamente 40 estabelecimentos, classificados em restaurantes, restaurantes temáticos, lanchonetes, churrascarias, petiscarias, entre outros.

Atualmente, devido o aumento da oferta de estabelecimentos comerciais, o sentido foi ampliado e vários são os conceitos de empreendimentos gastronômicos: restaurantes, fastfoods, delivery ou locais mais sofisticados. O conceito de um estabelecimento pode variar de acordo com aspectos como as características do público alvo e do mercado concorrente, o padrão de serviços a ser oferecido, além das definições relacionados ao menu do local e os tipos, quantidades e variedades dos pratos a serem contemplados no cardápio (BROOKES, 2005; OLIVEIRA, 2006).

Já os atrativos turísticos totalizam 20, exemplificado nas figuras ilustrativas a seguir, nos segmentos de aventura, de natureza e cultural. Composto por local, objetos, equipamentos, eventos ou manifestações, o atrativo turístico é capaz de motivar o deslocamento de pessoas para conhecê-lo. Os atrativos turísticos classificam-se em naturais; culturais; de negócios; eventos programados; de saúde; de lazer, entre outros (MTUR, 2007). Para Boullón (1983) o atrativo é matéria-prima do turismo sem a qual um país, uma região ou uma cidade não poderiam empreender o desenvolvimento turístico. $\mathrm{O}$ atrativo é elemento responsável pelo desencadeamento do processo turístico (VALLS, 2006). 


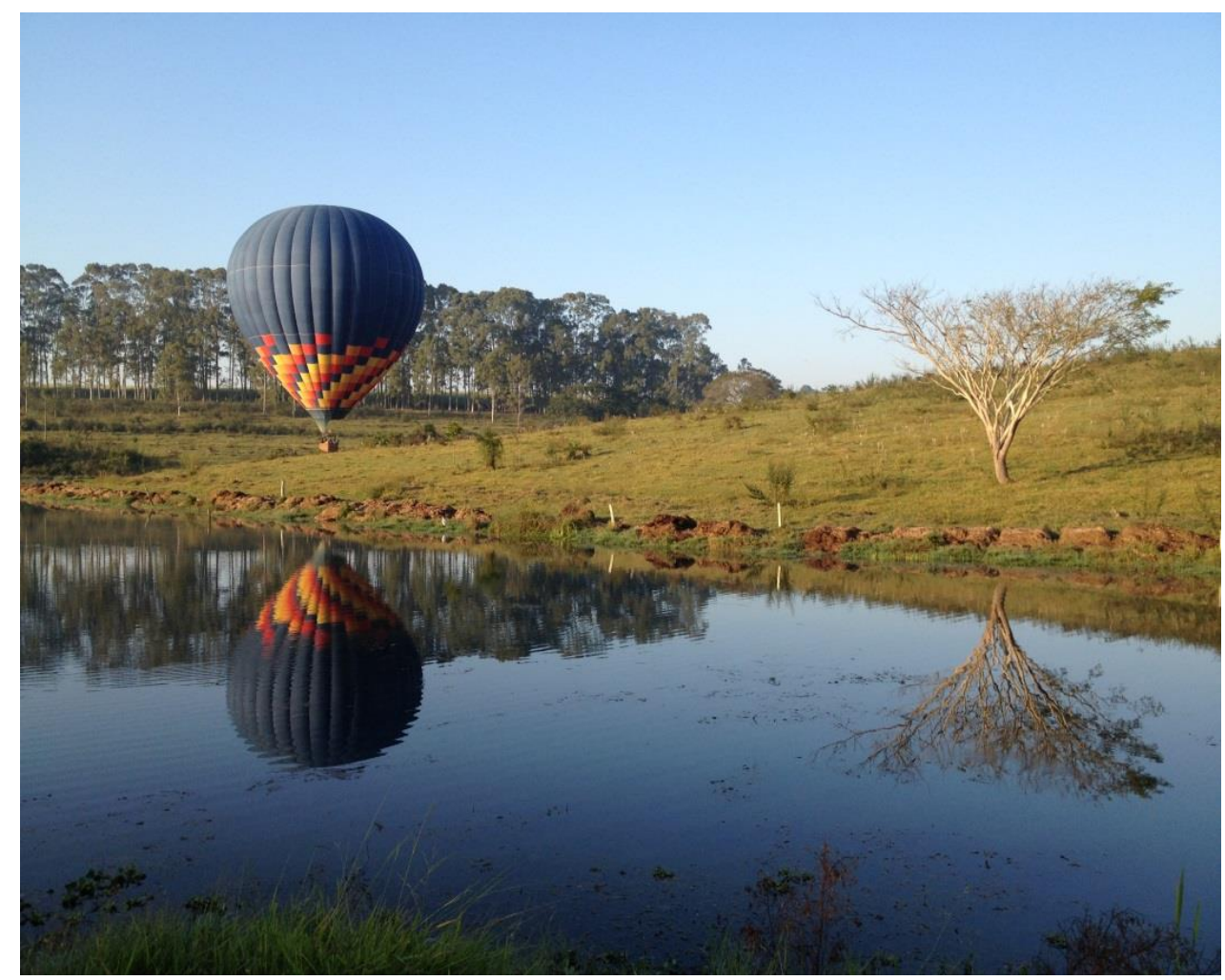

Figura 4 - Voo de balão

Fonte: AirBrasil - São Pedro, SP.

Os principais atrativos e atividades do município, no segmento de aventura, são balonismo - passeio de balão com uma hora de duração pelo céu de São Pedro, Águas de São Pedro e Piracicaba; cachoeirismo - banho de cachoeira em propriedades particulares que possuem infraestrutura de hospedagem e alimentação; cavalgada - passeio de cavalo em meio a estradas rurais, conduzido por profissionais da área equestre.

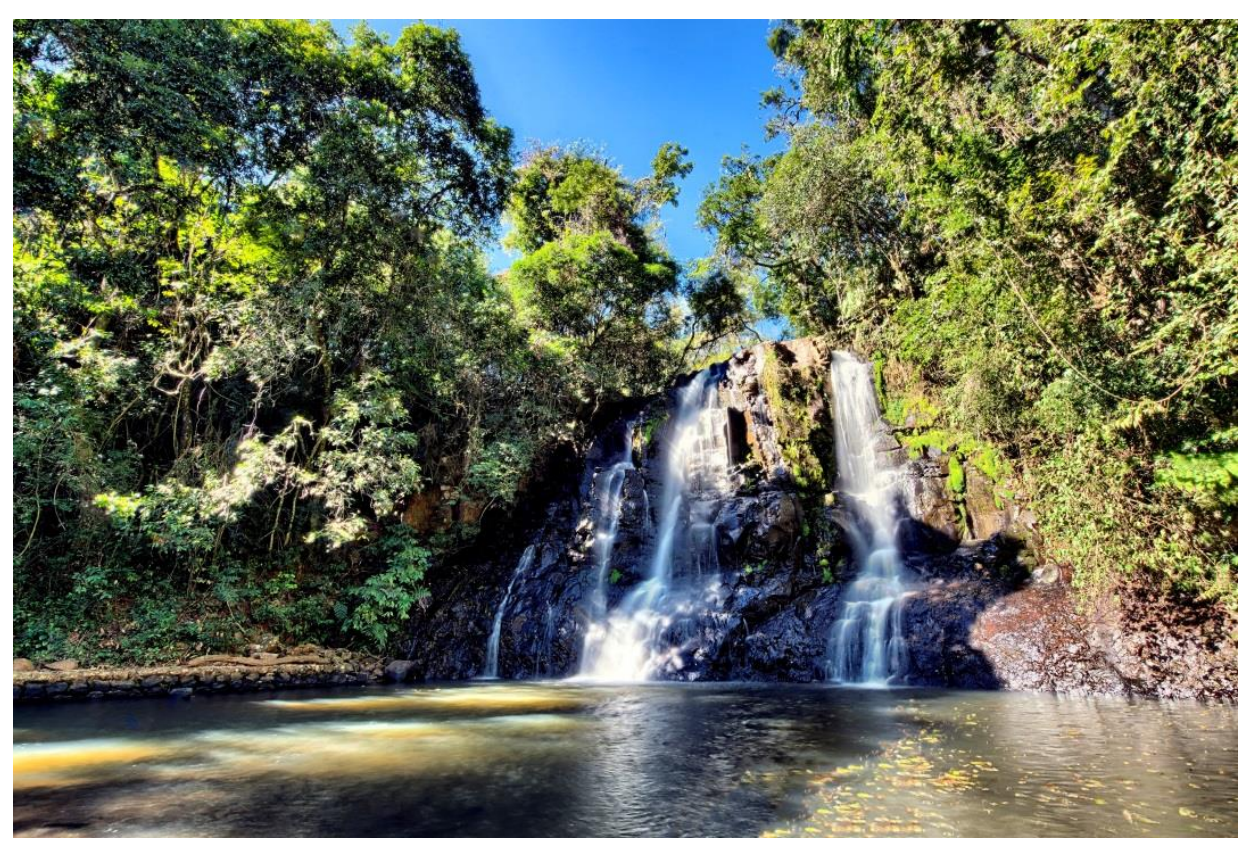

Figura 5 - Cascata Dorigon

Fonte: Arquivo Prefeitura Municipal de São Pedro, SP. 
Passeios 4x4 - passeios de jipes em trilhas e estradas municipais; tirolesa - atividade desenvolvida no Alto da Serra, em um empreendimento particular; e voo livre - voo de parapente praticado por pilotos profissionais individualmente ou por duas pessoas complementam a oferta do segmento.

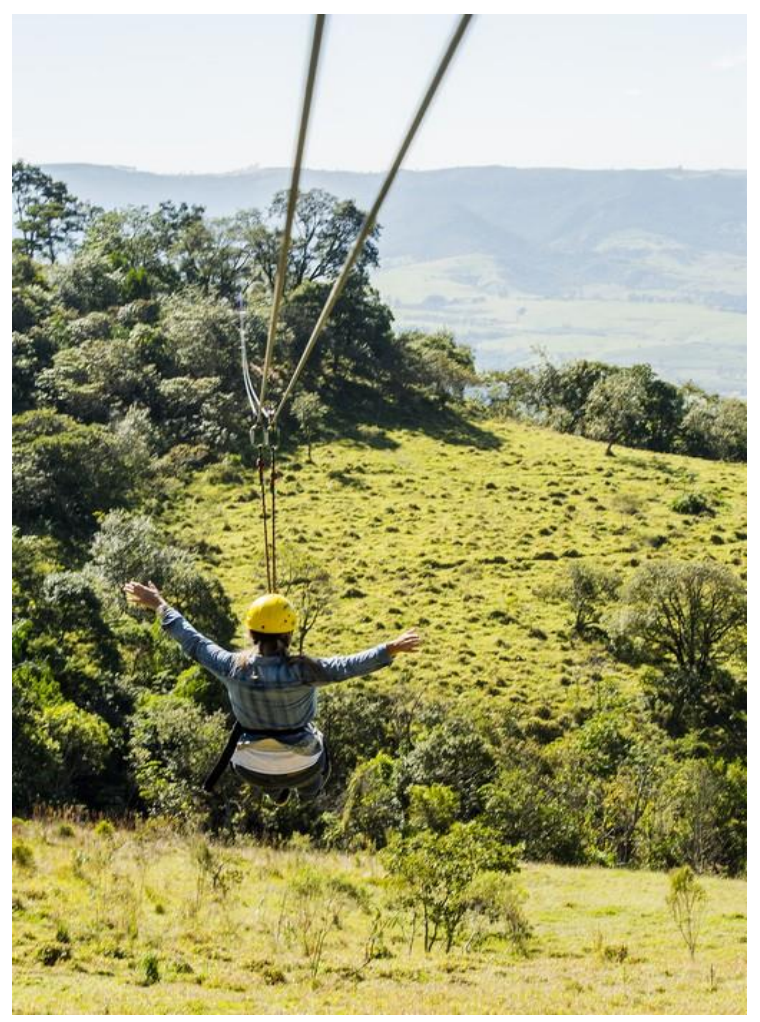

Figura 6 - Tirolesa

Fonte: Arquivo Prefeitura Municipal de São Pedro, SP.

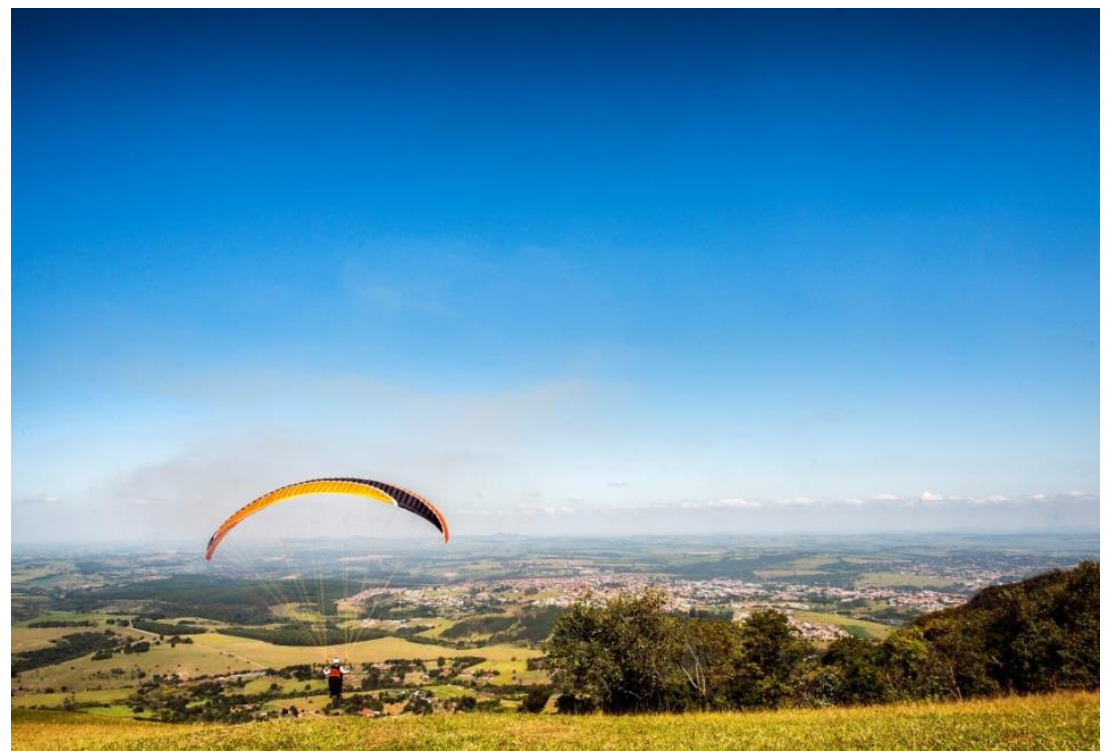

Figura 7 - Voo Livre

Fonte: Arquivo Prefeitura Municipal de São Pedro, SP. 
O ecoturismo, introduzido no país no final da década de 1980, refere-se a atividades que utilizam, de maneira sustentável, o patrimônio natural e cultural. Os principais atrativos são os parques municipais "Marcelo Golinelli", "Aureliano Esteves" e "Maria Angélica Manfrinato".

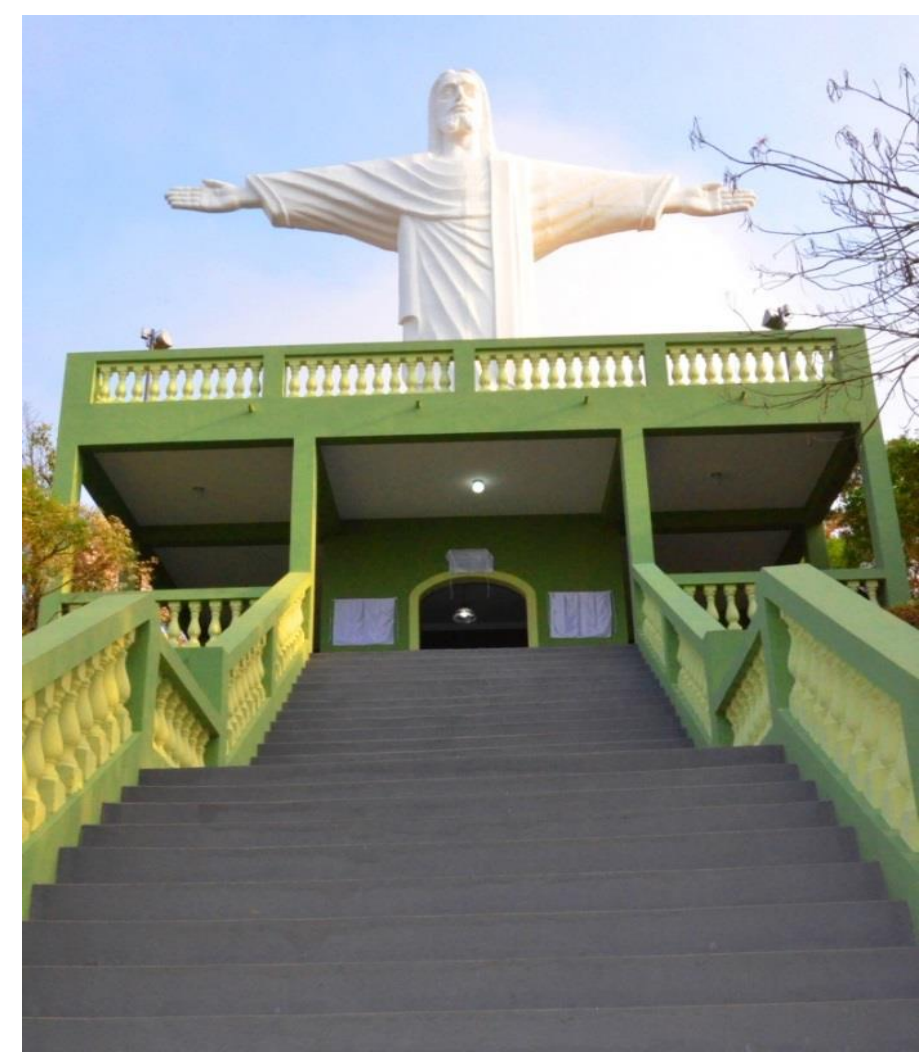

Figura 8 - Parque Aureliano Esteves - do Cristo

Fonte: Arquivo Prefeitura Municipal de São Pedro, SP.

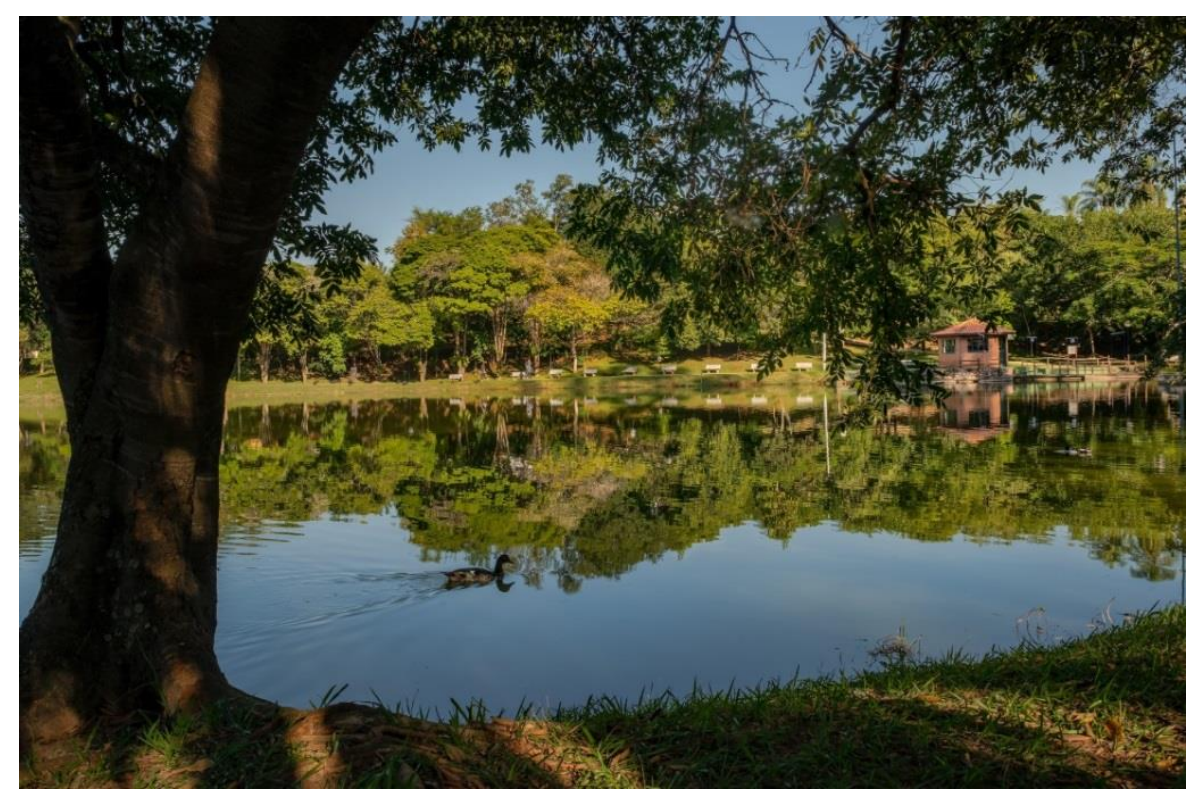

Figura 9 - Parque Maria Angélica Manfrinato

Fonte: Arquivo Prefeitura Municipal de São Pedro, SP. 
A relação entre turismo e cultura é intrínseca e motiva diversas reflexões entre órgãos da esfera federal como Ministérios do Turismo e da Cultura e Embratur - Instituto Brasileiro de Turismo - há anos. Os atrativos culturais da Estância são Arts’ Trama; Igreja Matriz; Igreja Presbiteriana Bairro dos Gomes; Museu e Praça Gustavo Teixeira.

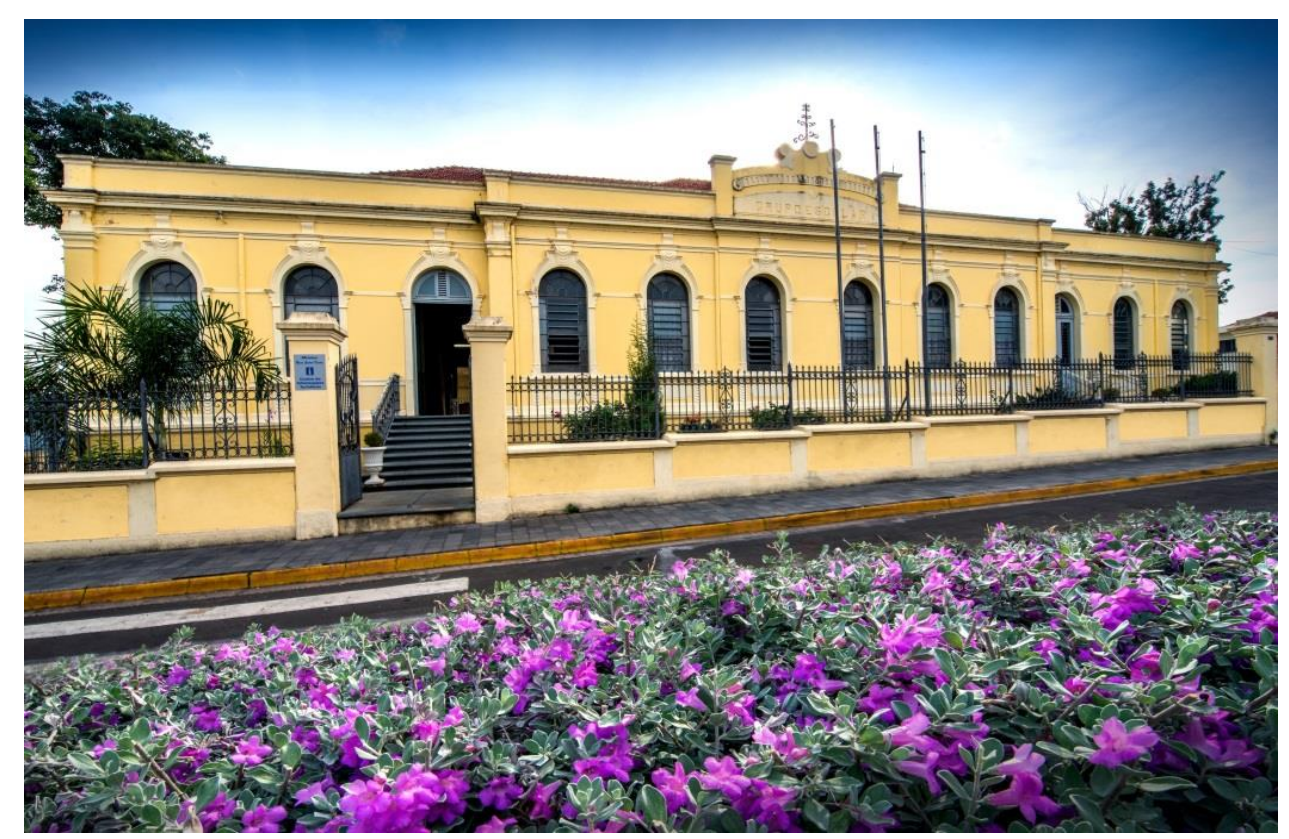

Figura 10 - Museu Gustavo Teixeira

Fonte: Arquivo Prefeitura Municipal de São Pedro, SP.

As Feiras de Artes e Artesanato e do Produtor Rural; Capela de Santo Antônio; Antiquário Vila Del Capo e Cachaças da Diretoria e Catedral fazem com que a oferta do segmento e torne completa, tanto no alto da serra quanto no centro da cidade.

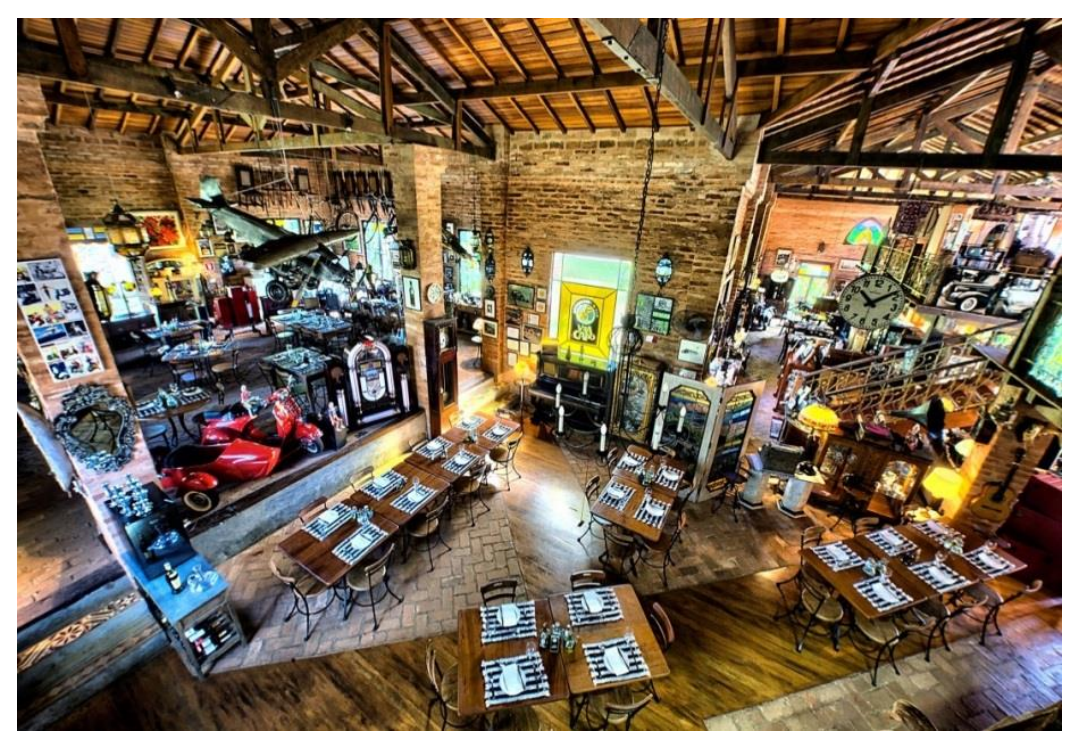

Figura 11 - Antiquário Vila Del Capo

Fonte: Arquivo Prefeitura Municipal de São Pedro, SP. 
Com o intuito de uma melhor compreensão acerca da adequação da oferta turística local, faz-se necessário um estudo sobre o perfil da demanda que visita a Estância.

A pesquisa de demanda elaborada para o Plano Diretor de Turismo foi realizada no segundo semestre do ano de 2014 e no primeiro de 2015. Foram entrevistados 105 turistas, encontrando-se estes em hotéis, restaurantes e atrativos turísticos (SÃO PEDRO, 2015).

A pesquisa apontou que a faixa etária de $63 \%$ dos turistas está entre 35 e 59 anos; $62 \%$ possuem renda familiar entre $\mathrm{R} \$ 1.245,00$ e $\mathrm{R} \$ 2.488,00 ; 87 \%$ residem na cidade de São Paulo e nas regiões do Grande ABC; 52\% viajam acompanhados da família; $83 \%$ se deslocam por meio de automóveis; $63 \%$ permanecem no destino de uma a três diárias; $52 \%$ viajam motivados pela aventura e pela natureza; $62 \%$ conheceram o município por meio de indicações de amigos e $60 \%$ se hospedam em empreendimentos hoteleiros locais.

Diante a esses percentuais conclui-se que o perfil do turista que visita a Estância Turística de São Pedro é adulto, de classe média, acompanhado da família, oriundo da grande São Paulo e que permanece, em média, quatro dias nos hotéis locais. 


\section{DISCUSSÃO DA PESQUISA}

\subsection{ESPAÇOS PÚBLICOS E MOBILIÁRIOS URBANOS NA HOSPITALIDADE}

Espaço público é o espaço de uso coletivo aos usuários em geral, administrado tanto pelo Estado - administração pública - quanto pela iniciativa privada. Esse espaço permite o direto de ir-e-vir, ou seja, circulação, lazer e recreação são livres. (YÁZIGI, CARLOS e CRUZ, 2000).

Grinover (2007) afirma que os espaços públicos expressam a cidade em sua forma arquitetônica e social. Permitem, ao mesmo tempo, comunicação e sociabilidade, aumentando assim a qualidade de vida da população.

Os espaços públicos são os lugares privilegiados para a vida cotidiana, para a sociabilidade, a civilidade, a ordem pública, a cidadania e a hospitalidade urbana. São os espaços públicos que dão a qualquer conglomerado urbano a possibilidade de várias experiências espaciais, em terras de vivências humanas e de prazer estético; onde se possibilitam e se exercitam a escolha, a liberdade e a hospitalidade. (GRINOVER, 2007).

Faz-se necessário salientar que a cidade é um espaço artificial, construído pelo homem com o objetivo de se conviver em sociedade. O deslocamento das pessoas dentro das cidades é auxiliado pela paisagem urbana, pois é por meio de seus elementos formais que as pessoas identificam e armazenam na memória imagens e informações da cidade.

Os espaços são planejados com infraestrutura adequada, permitindo o desenvolvimento de atividade de entretenimento e lazer. Os atrativos turísticos estão aliados a bens e serviços de qualidade, definindo o espaço turístico. (GRINOVER, 2007).

Dentre os diversos logradouros do espaço turístico urbano está a praça. Boullón (2002), a conceitua como área nítida, relativamente pequena diante da superfície total de uma cidade, porém de extrema importância para a formação da imagem turística da mesma. Para Robba e Macedo (2003) a praça é definida como espaço livre urbano, destinado ao lazer e ao convívio da população, acessíveis aos cidadãos e livres de veículos.

$\mathrm{Na}$ Antiguidade, as cidades se formavam a partir dos seus espaços de convivência. Ser cidadão e pertencer à cidade, era habitar os lugares de reunião, era compartilhar o culto, participar das assembleias, assistir às festas, vivenciar os espaços, participando da vida pública. A praça simbolizava a própria cidade, pois era nesse espaço que as atividades cotidianas se desenvolviam (COULANGES,1975).

$\mathrm{Na}$ Antiguidade greco-romana, a praça era o espaço público de maior importância da cidade e funcionava como seu centro vital. Materializada na figura da Ágora ou do Fórum, a 
praça, com seu conjunto arquitetônico, desempenhava um papel crucial: era o locus publicci da vida citadina. Era nesse espaço que o conceito de civitas se fazia presente.

Ao integrar todos os elementos da sociedade, a praça passa a ser também o lugar de articulação entre os diversos estratos sociais. Voltada ao lazer contemplativo, convivência da população, lazer esportivo, recreação infantil e lazer cultural.

Diante da diversidade de configurações urbanas existentes, a praça se apresenta como um locus privilegiado da cidade, principalmente pelo seu caráter de espaço multifuncional. Nos dias de hoje, as praças desfrutam de um enorme prestígio, sobretudo a partir da vertente da "qualidade de vida", presente nos projetos de revitalização urbana. Essa importância pode ser constatada nas políticas de intervenção, nas quais a praça aparece como elemento fundamental. Busca-se, dessa maneira, resgatar valores históricos, evidenciando significados perdidos tanto na arquitetura quanto no urbanismo.

Robba e Macedo (2003) atribuem às ruas importância crucial uma vez que trazem as pessoas que ocupam a praça, ao mesmo tempo em que afirmam que a manutenção dos espaços públicos da cidade é fundamental para garantir sua existência. Pode-se associar a falta de usuários a falta de manutenção, e esta é ocasionada pela falta de investimentos públicos.

Dessa maneira, o espaço público perde o significado e fica vulnerável aos agentes da transformação urbana (poder público e mercado imobiliário).

As praças são conceituadas, ainda, como áreas verdes. Essas áreas são destinadas para comportar o verde urbano, além de um indicador importante para a qualidade ambiental. Ao substituir o verde das paisagens pelo concreto das construções nas cidades mudanças acontecem nos padrões naturais de percolação das águas, fazendo das áreas urbanas sinônimos de desequilíbrio dos ecossistemas e de vários processos de erosão (LOBODA, 2003).

Por abrigar vasta vegetação em seu espaço, as áreas verdes arborizam as vias públicas e tal ação atenua ruídos, retém de pó, reoxigena o ar, além de oferecer sombra e a sensação de frescor.

Tendo como função a interatividade entre os espaços públicos e os usuários, além de elemento funcional, o mobiliário urbano é uma referência visual que identifica um espaço público, um bairro e até mesmo uma região. Mourthé (1998) define em seis as categorias de mobiliário urbano: elementos decorativos (esculturas, painéis); mobiliário de serviço (lixeiras, banheiros públicos, abrigos de ônibus); mobiliário de lazer (bancos de praça, mesas de jogos); mobiliário de comercialização (quiosques, bancas de jornal e revistas, bares em áreas 
públicas); mobiliário de sinalização (placas informativas); mobiliário de publicidade (outdoors).

Coerência no momento de implantação destes equipamentos no espaço público se faz de extrema importância. Mourthé (1998) afirma "é necessário considerar aspectos históricos, culturais e climáticos para que a busca da melhor qualidade de vida nos centros urbanos não implique em ruptura com a história e a cultura da comunidade".

\subsection{DE JARDIM PÚBLICO À PRAÇA GUSTAVO TEIXEIRA}

Registros jornalísticos apontam o ano de 1897 como marco do nascimento do primeiro Jardim Público em São Pedro. Em busca de um local para os passeios e encontros, jovens da cidade organizaram um espetáculo teatral para arrecadar fundos para a construção de um jardim (SANTOS, 2009). Notava-se o engajamento da população em benefício das melhorias locais. Jovens estavam dispostos a ajudar, independente das condições sociais a que pertenciam (MANO, 2006).

O Jardim Público de São Pedro foi inaugurado em 31 de dezembro de 1897, com festa, queima de rojões e apresentação da banda Aurora São-Pedrense. Registros de 1910 destacam o domingo como dia mais esperado da semana, pois os trabalhadores vinham à cidade assistir a Santa Missa, visitar os parentes e amigos, e paquerar nos passeios pelo jardim (SANTOS, 2009).

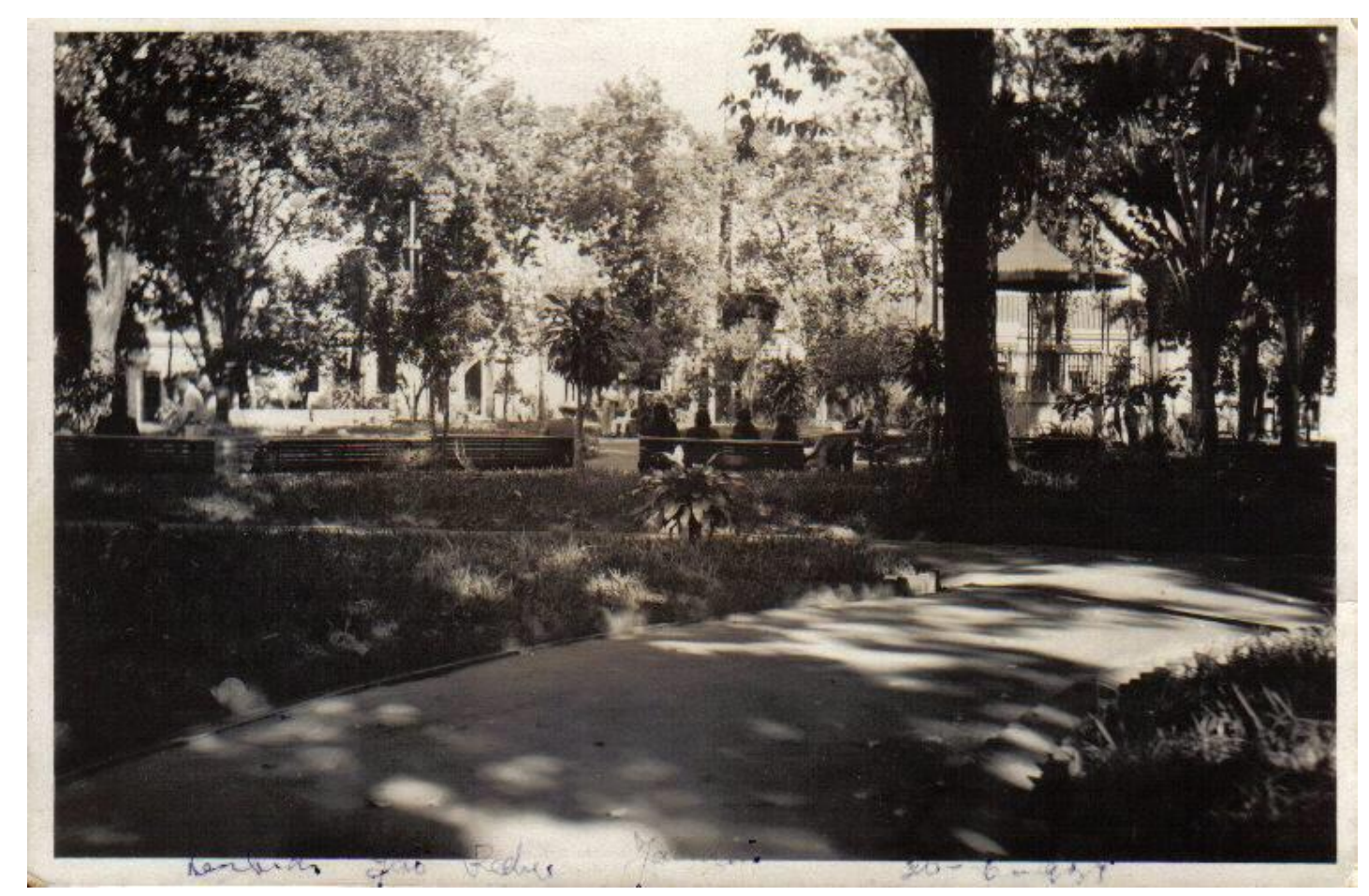

Figura 12 - Desenhos dos passeios em 1957

Fonte: Arquivo pessoal Sr. Neto Matarazzo 
A vida social da vila concentrava-se no entorno do Jardim. Ao final das tardes de domingo, a banda se apresentava. As folias de momo aconteciam nas imediações do coreto, onde mulheres com fantasias e homens mascarados dançavam ao som da corporação musical Aurora São-Pedrense.

Na década de 1890, o Hotel da Nhá Bella, era referência de educação a todos na vila, pois em sua estrutura reuniões educacionais aconteciam. Localizado no Largo da Matriz, era também palco de decisões políticas, uma vez que abrigava a sala onde eram realizadas as audiências judiciais (SANTOS, 2009).

A imagem abaixo retrata o poeta Gustavo Teixeira, na década de 1920, usando o Jardim Público como inspiração para seus poemas, uma vez que diversos poemas publicados no livro Poesias Completas de Gustavo Teixeira possuem como tema e como cenário o Jardim Público. Passava horas ali, observando o espelho d’água e escrevendo seus versos (SANTOS, 2009).

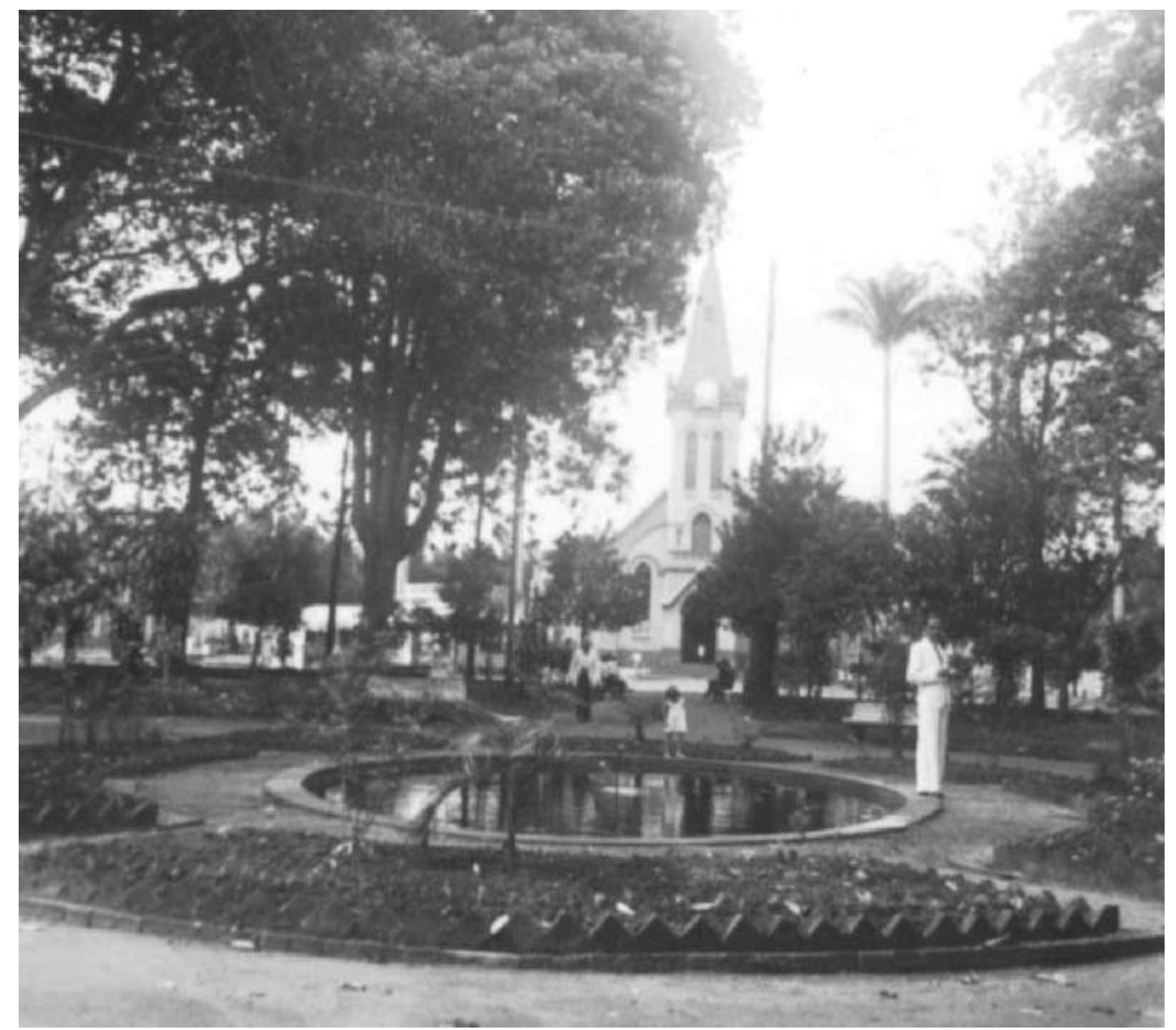

Figura 13 - Poeta Gustavo Teixeira no Jardim Público 1920

Fonte: Arquivo pessoal Sr. Neto Matarazzo 
Em 06 de setembro de 1937, por sessão magna da Câmara Municipal de São Pedro, outorgou-se o nome de Praça Gustavo Teixeira ao antigo Jardim Público Municipal. Palco de momentos históricos da cidade, a Praça abrigou em seu coreto discursos durante a Revolução de 1932. Nesse mesmo local, comícios eleitorais eram realizados, pois nas instalações da Associação Desportiva - localizada ao lado da Praça - aconteciam as apurações eleitorais (MANO, 2006).

A tradição dos passeios no jardim foi se prolongando, exemplificado na figura 13. Nas décadas 1960 e 1970, os jovens encontravam-se nas tardes de domingo para o "footing", onde meninos e meninas davam suas voltas em sentidos opostos, encontrando os olhares de quando em quando. As moças andavam na área mais interna da Praça, os rapazes no passeio de fora. Jovens reuniam-se na Praça antes das brincadeiras dançantes da Associação Desportiva e Recreativa Sampedrense (SANTOS, 2009).

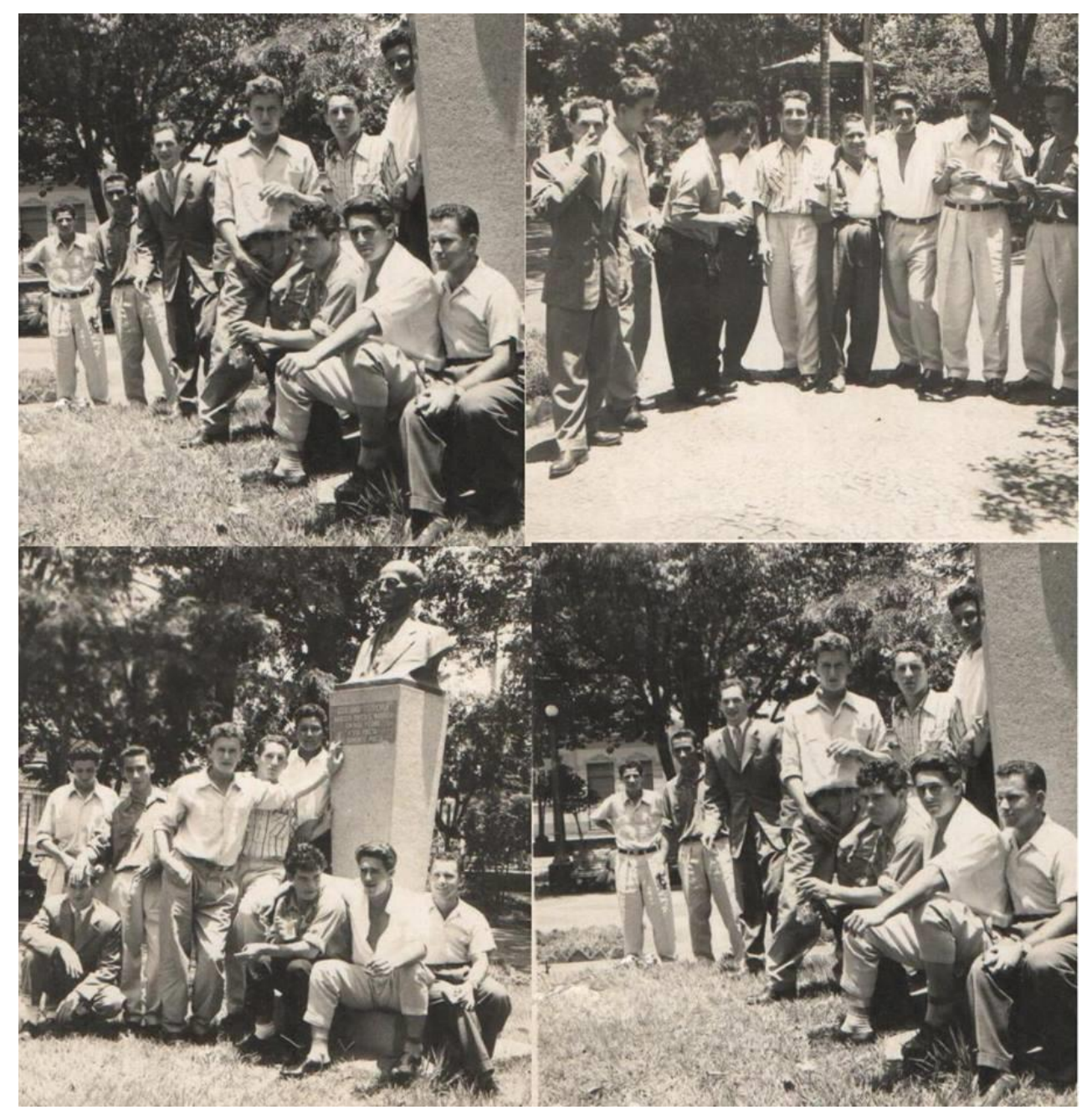

Figura 14 - Encontro de amigos em 1956

Fonte: Arquivo pessoal Sr. Neto Matarazzo 
Mesmo com o crescimento urbano local, no decorrer dos anos, a Praça continua a receber eventos. Em seu espaço foram realizadas duas edições do Festival Nacional de Choro; abrigou, em seu entorno, o resgate cultural da colonização do município: Festa Italiana gastronomia, decoração, apresentações artísticas com nomes renomados como Tony Angeli, Jerry Adriani e Agnaldo Rayol; apresentações teatrais e circenses; quermesse do Padroeiro "São Pedro", entre outros (SANTOS, 2009).

Ao comparar suas atividades com a praça Santa Cruz, localizada em um ponto comercial da cidade, a Praça Gustavo Teixeira recebe um maior número de atividades culturais. A população identifica o local como um "Centro Histórico e Turístico". Já a Praça São José abriga em sua estrutura somente uma quermesse anual. Nos dias de hoje, os fiéis realizam também apresentações religiosas como encenações da Paixão de Cristo. Porém, a Praça Gustavo Teixeira se destaca em número de atividades e visitantes.

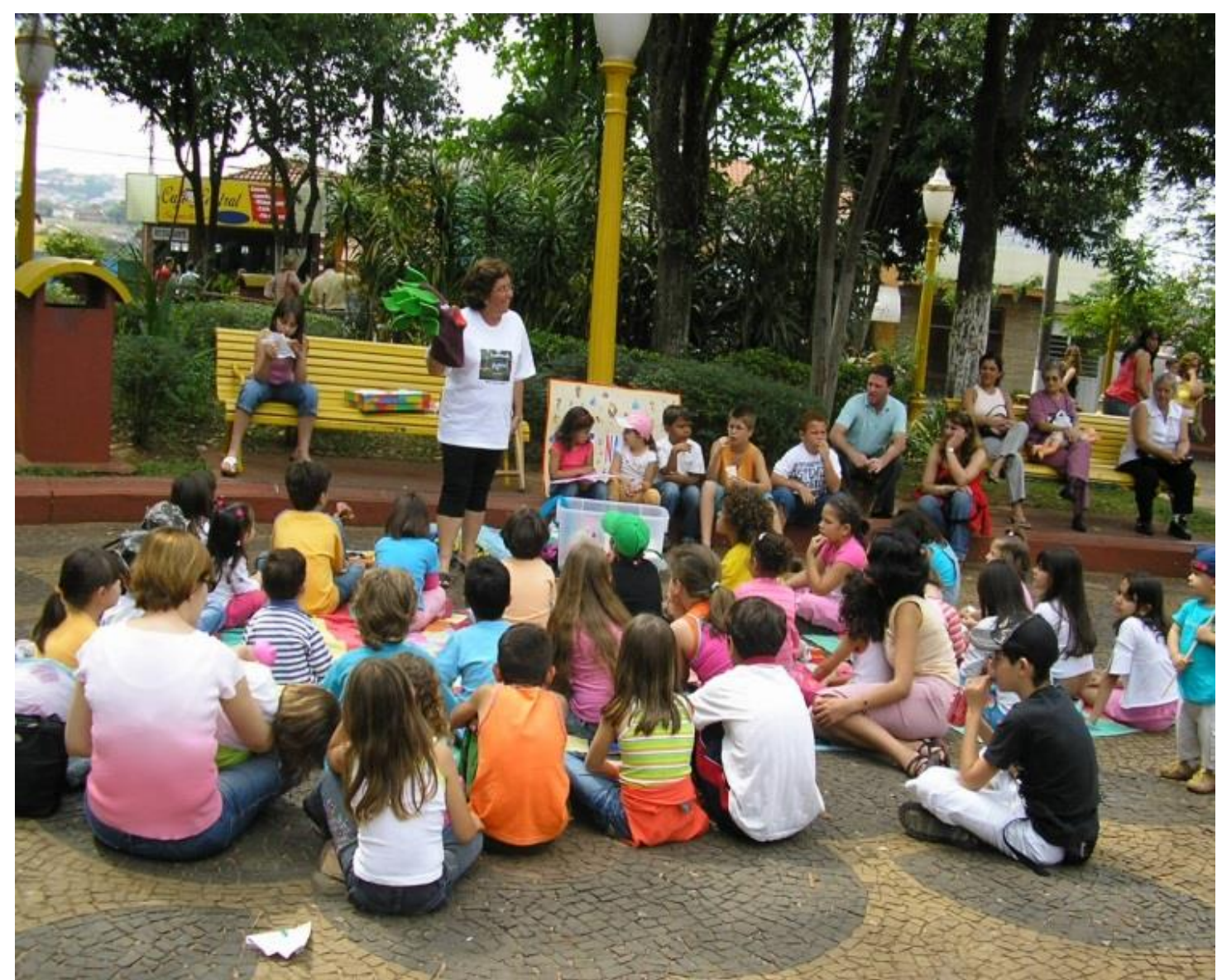

Figura 15 - Histórias infantis para crianças em 2009

Fonte: Prefeitura Municipal de São Pedro, SP. ${ }^{2}$

\footnotetext{
${ }^{2}$ As fotos da Prefeitura Municipal de São Pedro são de uso público.
} 
Ao analisar a parte estrutural da Praça, identifica-se que a mesma possui coreto central; postes de iluminação em estilo colonial e lâmpadas de led; busto do Poeta Gustavo Teixeira; piso composto por pedras portuguesas; bancos de madeira; lixeiras; entradas com acessibilidade e piso tátil; bebedouros na área central.

A vegetação local, ilustrada na figura 15, é composta por pau brasil, oiti, sibipiruna, ipê, angico, pata-de-vaca, agapanto, asplênio, hera da alegria, íris azul, lírio da paz gigante, moreia, periquito, singonio, entre outros.

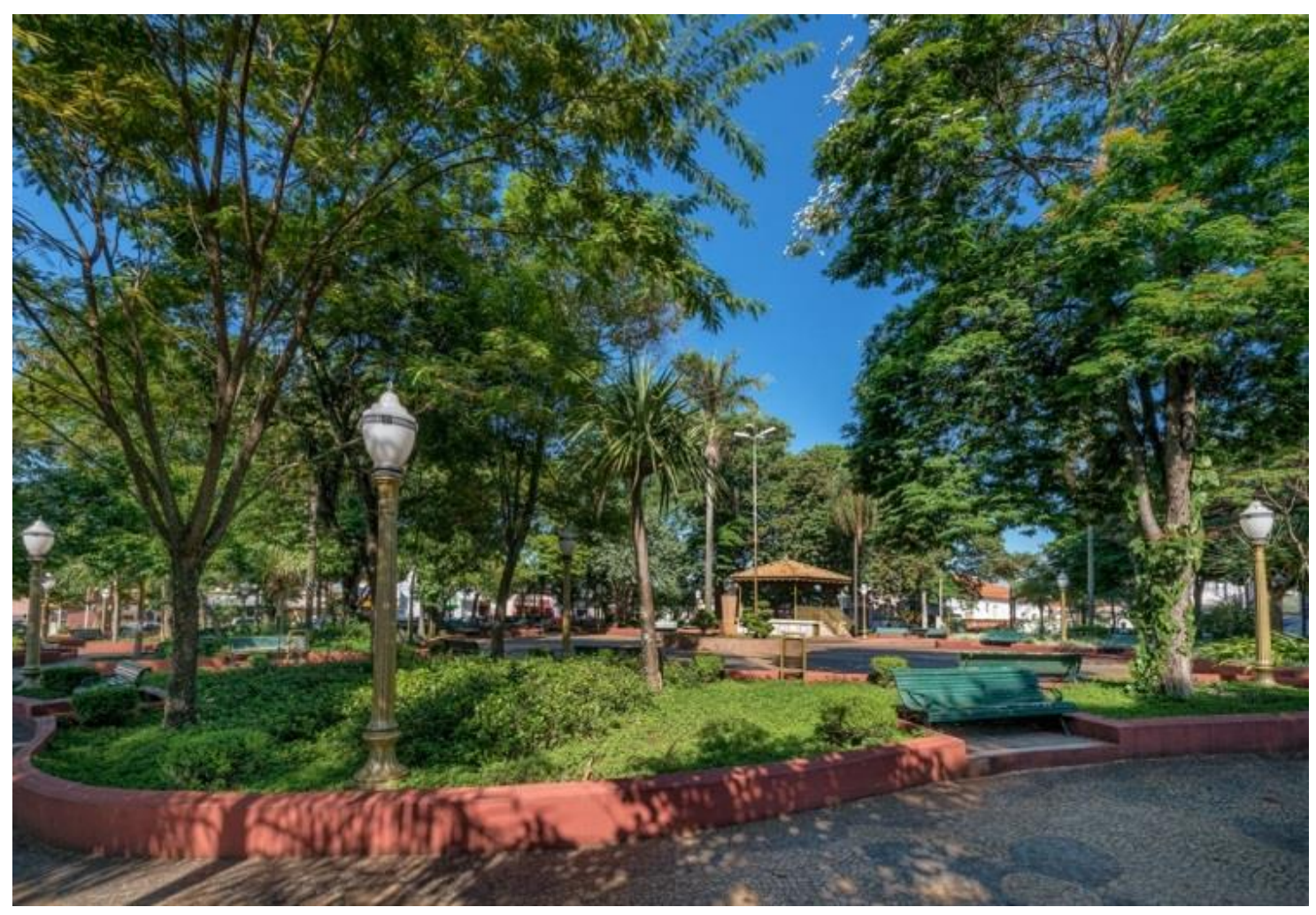

Figura 16 - Arborização no ano de 2014

Fonte: Arquivo Prefeitura Municipal de São Pedro, SP.

Nas últimas décadas, a estrutura da Praça, em seus $5.500 \mathrm{~m}^{2}$, recebeu quatro revitalizações. Todas mantiveram as antigas estruturas de corredores e canteiros e tiveram o acompanhamento da população, a fim de não haver descaracterização (SÃO PEDRO, 2015).

A Praça Gustavo Teixeira localiza-se entre as ruas Veríssimo Prado, Malaquias Guerra, José Estanislau de Oliveira e Joaquim Teixeira de Toledo. 

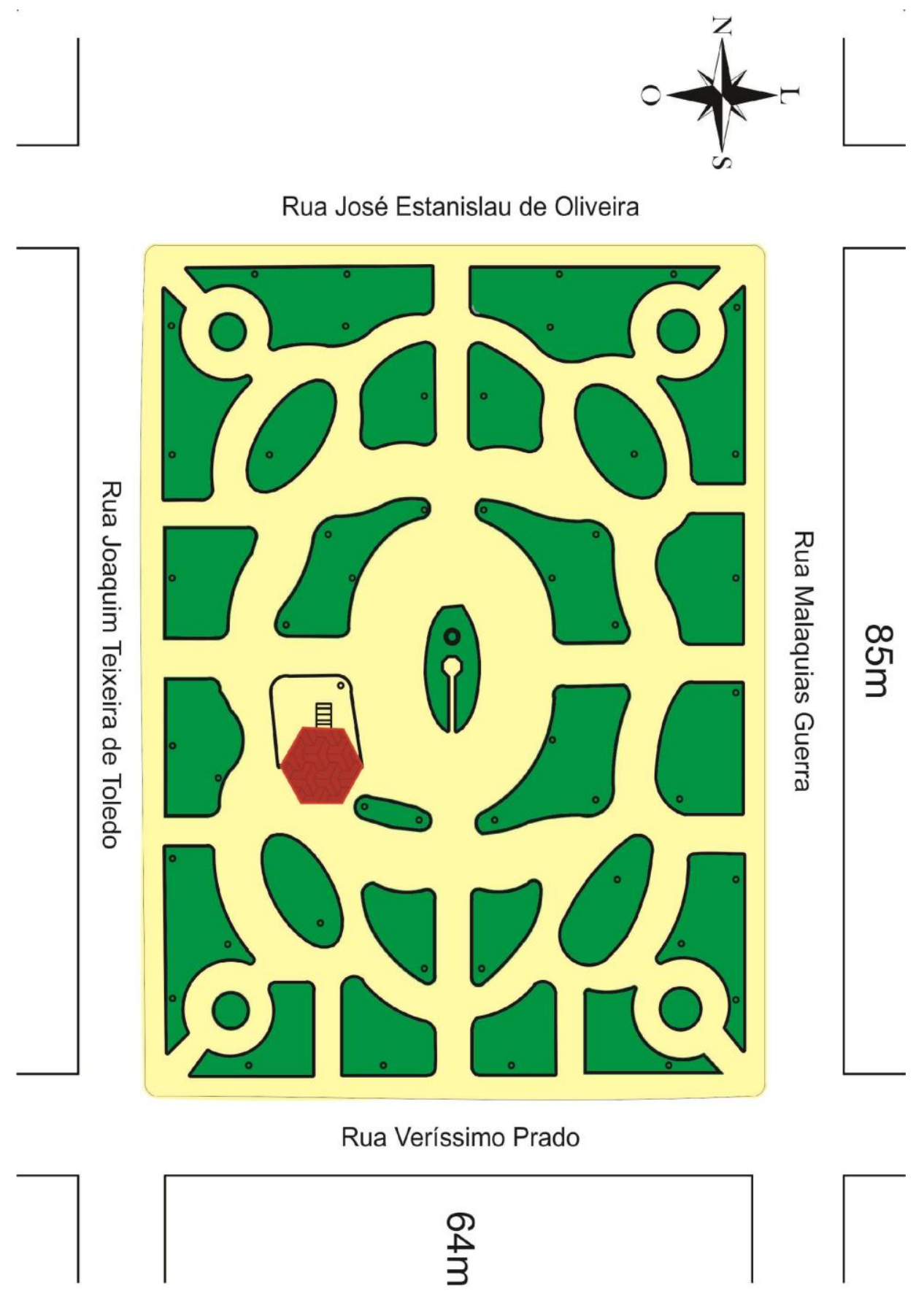

Figura 17 - Estrutura Física da Praça

Fonte: Arquivo Prefeitura Municipal de São Pedro, SP.

O entorno da Praça, uma vez composto por diversos comércios, pela Praça da Igreja Matriz e pelo Boulevard de Arte e Artesanato, é denominado de "centro turístico". As ruas Veríssimo Prado; Malaquias Guerra; Joaquim Teixeira de Toledo e José Estanislau de Oliveira abrigam imobiliárias; farmácias; sorveterias; milk shake; lojas de roupa feminina, calçados, enxovais e bordados; hotéis; doceria; restaurantes, associação desportiva e museu. 


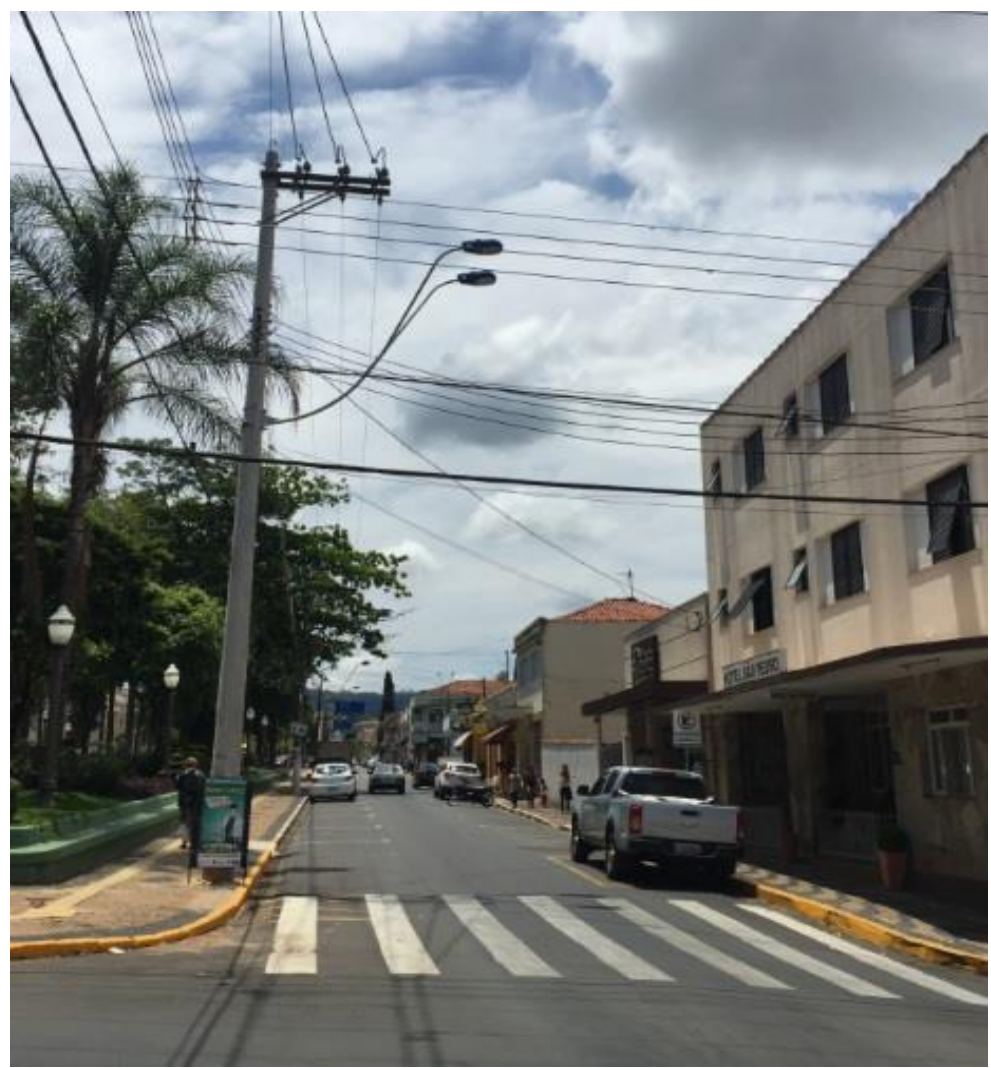

Figura 18 - Localização Praça em relação à Rua Malaquias Guerra Fonte: Própria autora, 31 de outubro 2016.

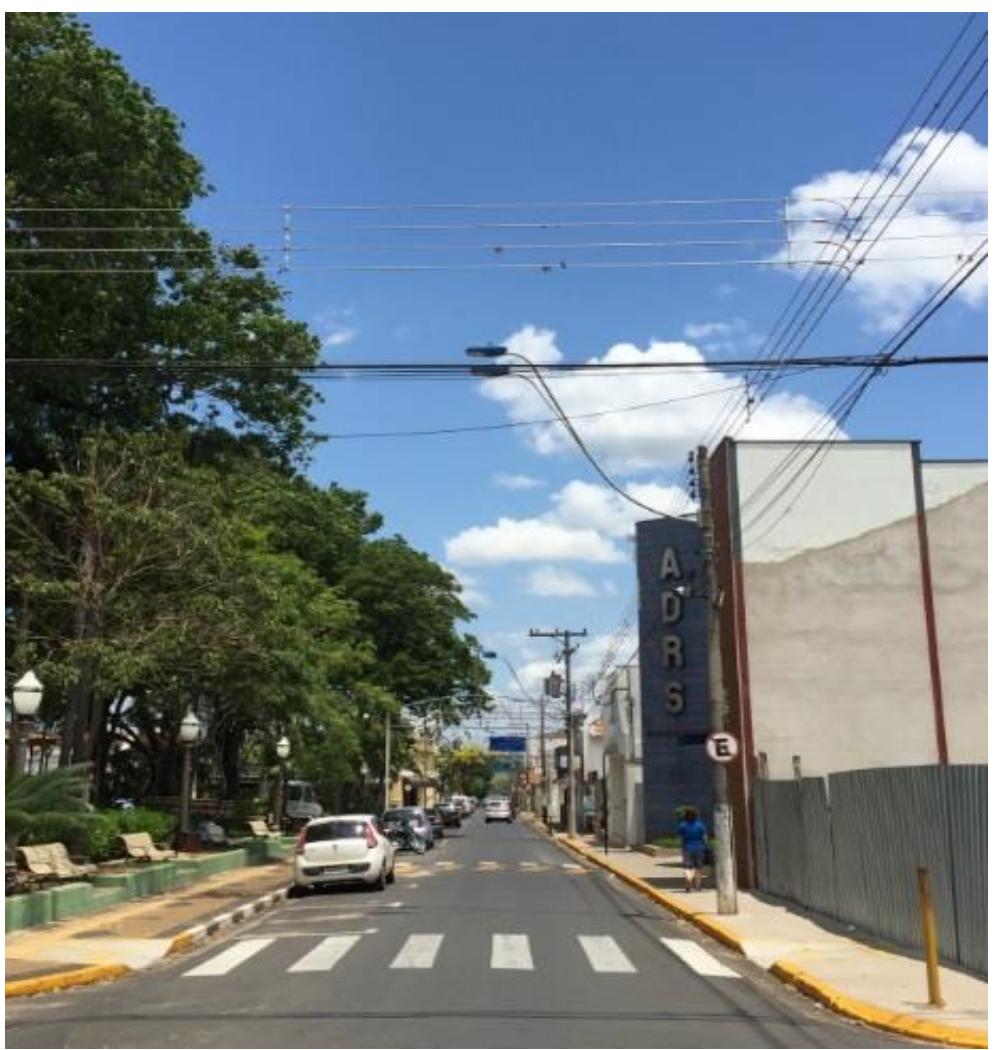

Figura 19 - Localização Praça em relação à Rua Joaquim Teixeira de Toledo Fonte: Própria autora, 31 de outubro 2016. 


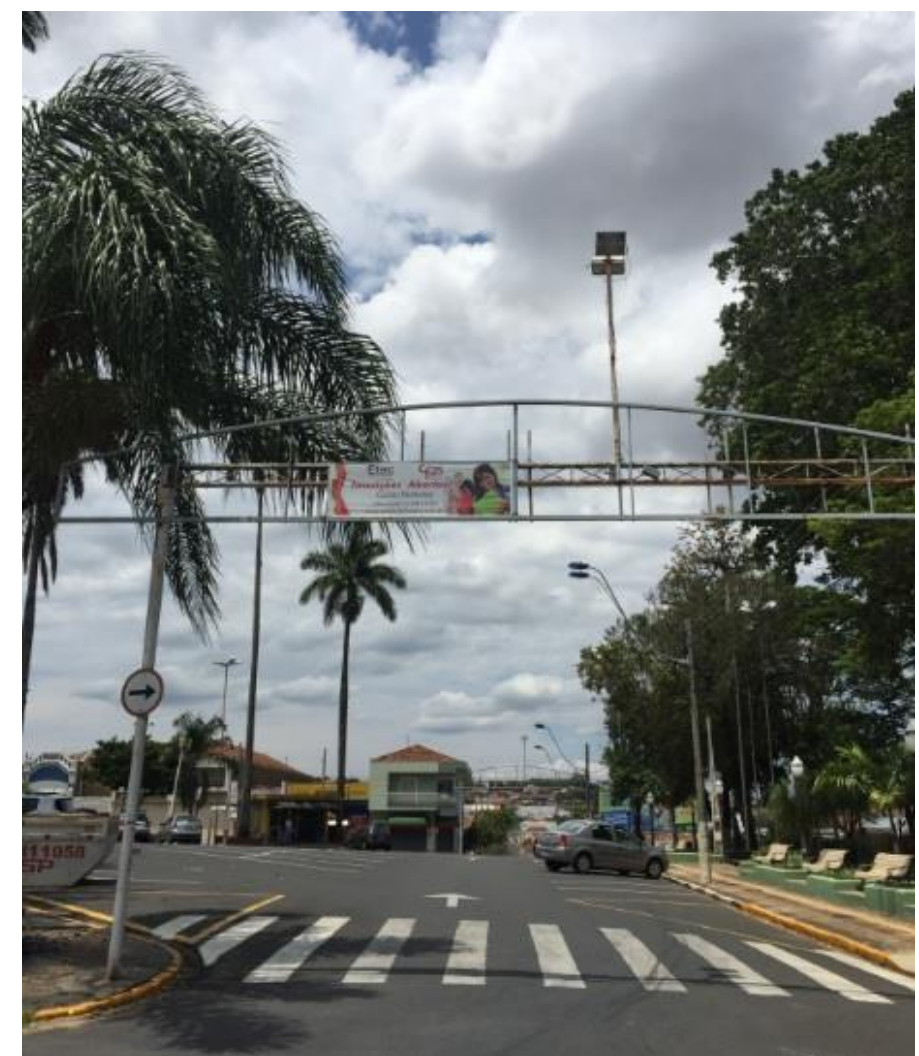

Figura 20 - Localização Praça em relação à Rua José Estanislau de Oliveira Fonte: Própria autora, 31 de outubro 2016.

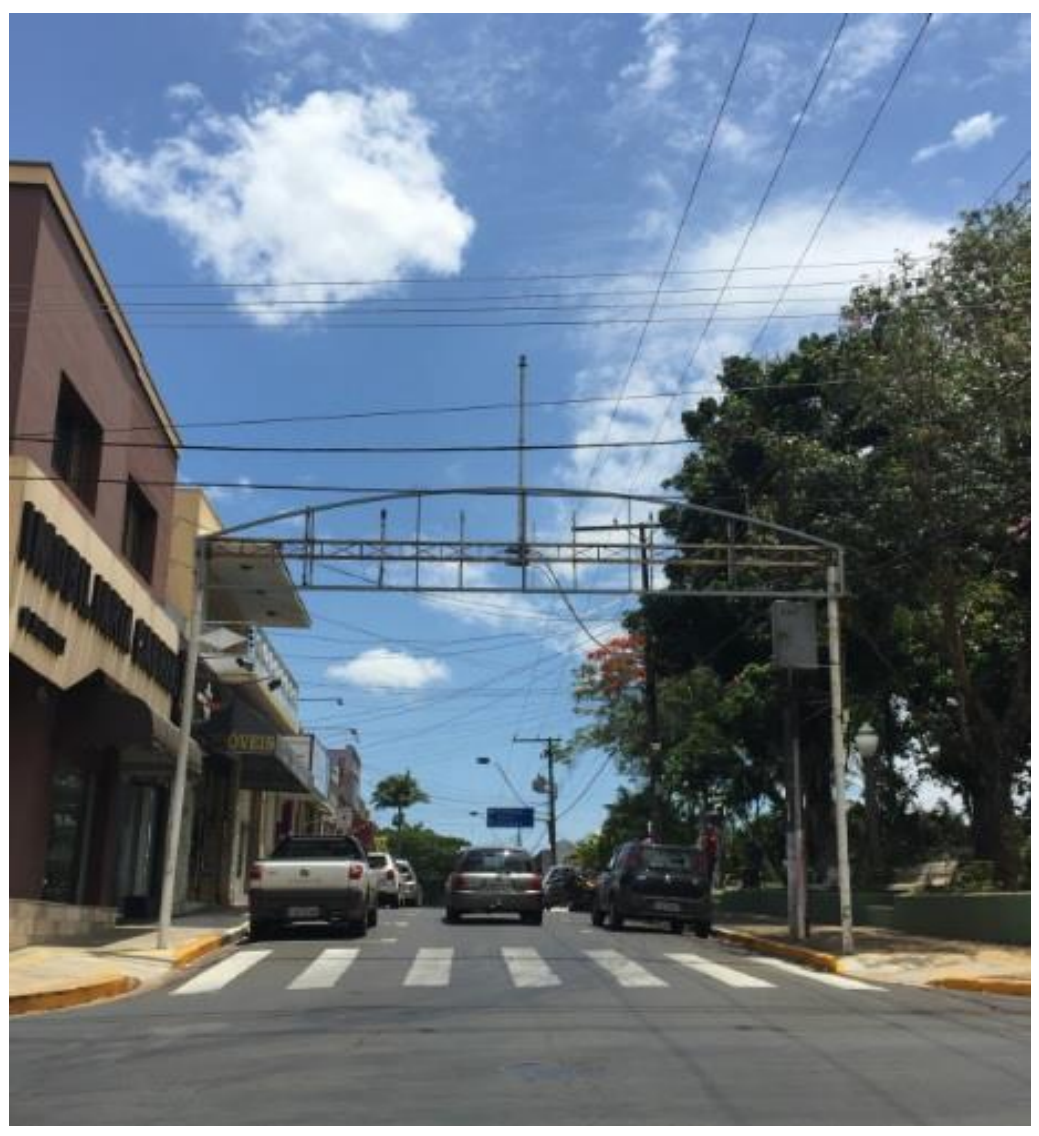

Figura 21 - Localização Praça em relação à Rua Veríssimo Prado Fonte: Própria autora, 31 de outubro 2016. 
Por localizar-se no centro da cidade, a praça está no trajeto de inúmeros atrativos naturais do alto da serra. Turistas, em finais de semana e feriados, passam pelo local e aproveitam para descansar e apreciar a gastronomia local.

No decorrer da semana, moradores descansam em sua área arborizada durante todo o dia. Alguns estão em horário de almoço, outros marcam encontros com os amigos ou levam seus filhos para brincar. São diversos os perfis e os motivos pelos quais as pessoas frequentam a Praça Gustavo Teixeira.

A importância da Praça permite ao Poder Público a promoção de ações tanto para moradores quanto para turistas durante o ano. Torna-se comum o encontro e o contato entre anfitrião e visitante.

\subsection{PERFIL DOS ENTREVISTADOS - ANÁLISE E DISCUSSÃO}

Baseando-se no conceito de Kauark, Manhães e Medeiros (2010), a pesquisa de caráter qualitativo e natureza exploratória, fazendo uso de questionário semiestruturado (Apêndice A) e perguntas abertas, foi aplicada em dois grupos que frequentam a Praça: moradores e turistas.

O grupo de moradores, composto por seis pessoas, possui envolvimento com o local de pesquisa em todos os momentos da vida. Um integrante possui empreendimento comercial no entorno, dois a visitam constantemente a lazer e três tiveram sua presença esporadicamente no decorrer da vida. As motivações do uso do espaço são lazer e trabalho.

O grupo de turistas, composto por mais seis pessoas, não possui envolvimento diário com o local. Um visitou a praça somente uma vez e cinco a visitam constantemente. A motivação pela qual frequentam a Praça é tranquilidade de cidade do interior; trabalho; lazer e férias.

Ao escolher os entrevistados priorizou-se faixas etárias, motivações, níveis de envolvimento supostamente diferentes, a fim de analisar a diversidade nas opiniões. Optou-se pelo número de doze entrevistas, seis moradores e seis turistas, pois as respostas tornaram-se repetitivas em alguns aspectos ao analisar toda a coleta. As entrevistas foram mantidas em sigilo devido ao receio na exposição de críticas e foram coletadas por meio de anotações (diário de campo) e gravações em aparelhos próprios

A primeira turista entrevistada é uma mulher de cinquenta e sete anos que reside na cidade de Paulínia - SP. A entrevista aconteceu em um domingo, no momento em que a entrevistada fazia compras nas lojas do entorno da Praça. Durante a conversa, que durou cerca 
de vinte minutos, as informações foram gravadas em um aparelho telefônico móvel. A turista visita a Praça todas as vezes que vem à cidade. Suas visitas são motivadas pela beleza e tranquilidade do local. Quanto ao acolhimento, a entrevistada acredita que a estrutura da Praça é acolhedora: bancos, coreto, colorido das plantas. Todas as vezes que a visitou, os moradores foram simpáticos, deram orientações e atenderam muito bem - refere-se às compras efetuadas no comércio do entorno. Em se tratando do item de acessibilidade, a visitante acha a localização de fácil acesso; o asfalto do entorno de boa qualidade; existe ponto de táxi próximo; acredita que os moradores também acham isso, pois sempre os encontra; e percebe a passagem de ônibus circulares nas ruas próximas. Para a dimensão de legibilidade, a Praça possui um "glamour" de cidade pequena; os caminhos internos são típicos de cidade pequena. Por fim, a dimensão da identidade foi a mais comentada. As lojas do entorno que comercializam artesanato, bordado ponto cruz são citadas: "é um lugar que nos atrai pelo artesanato, os bordados, os panos de prato, pelo comércio". A decoração natalina remete ao convívio familiar no espaço. Os passeios dos anfitriões fazem com que a visitante lembre-se do vai-e-vem em meio aos caminhos, onde as mulheres seguiam para um lado e os homens para outro. "A Praça ainda preserva os antigos valores das pessoas no convívio social”.

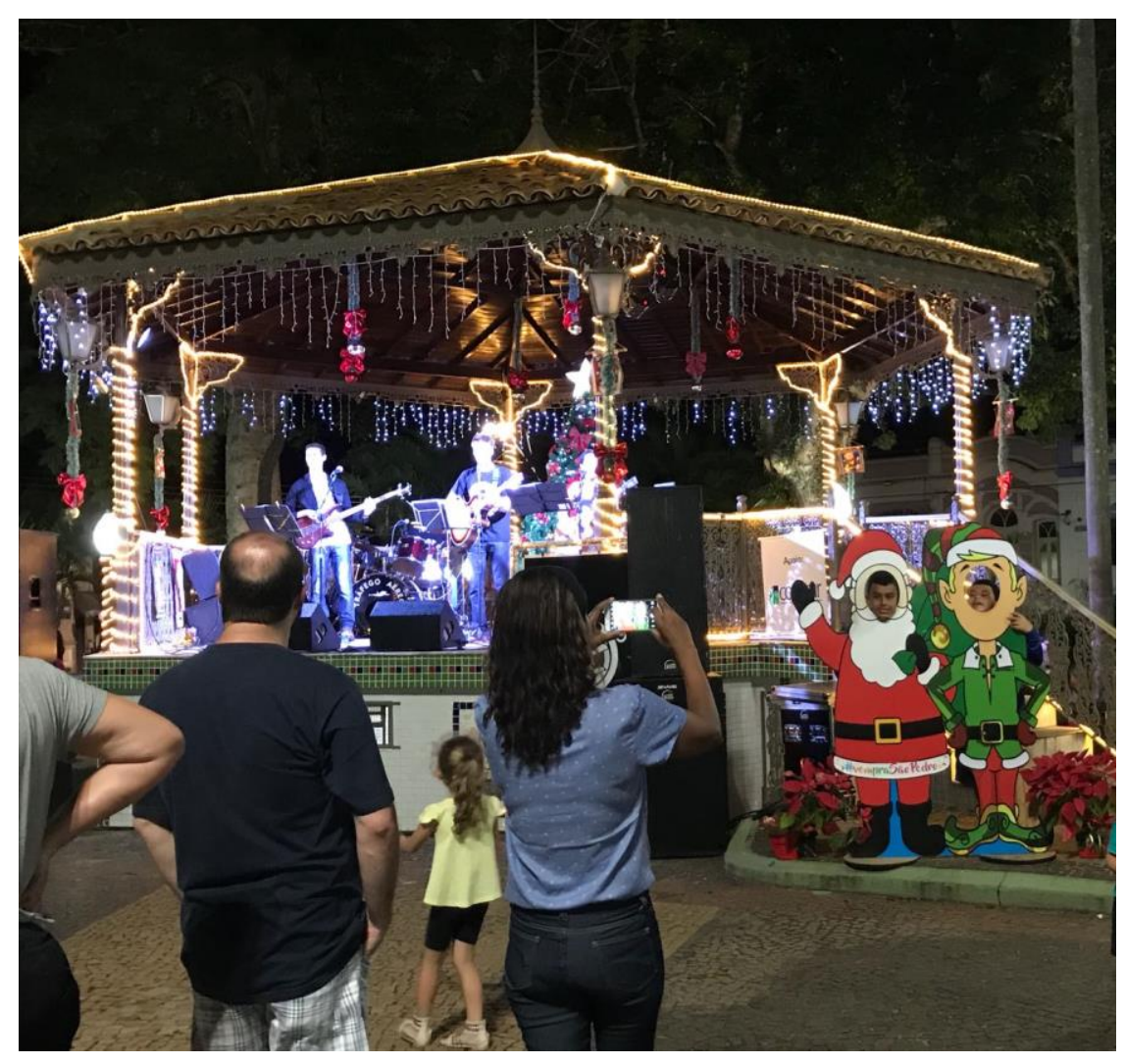

Figura 22 - Evento "Presente Cultural de Natal" Fonte: Própria autora, 09 de dezembro 2017. 
O segundo visitante entrevistado tem cinquenta e um anos de idade; reside na cidade de Santo André SP e estava acompanhado da família. O entrevistado foi abordado enquanto desfrutava de um momento de lazer na praça, em um sábado do mês de novembro. A conversa durou, aproximadamente, dez minutos e as informações e os relatos coletados foram registrados em um caderno de anotações. Esta é a primeira vez que visita a Estância de São Pedro e, consequentemente, a Praça. A viagem foi motivada pela tranquilidade de cidade do interior e pela natureza "temos amigos que já vieram passear em São Pedro e eles nos indicaram. Moramos em uma cidade grande e estamos cansados da correria do dia a dia. É muito difícil encontrar uma praça cuidada e segura perto de nossa casa". O visitante relatou que a cidade é acolhedora desde orientações no portal até o hotel em que estão hospedados. Os moradores são receptivos, atenciosos e fizeram inúmeras indicações de passeios, sendo o centro um deles "Soubemos que São Pedro foi a Capital do Bordado e resolvemos conhecer o comércio. Minha esposa comprou alguns panos de prato bordados na feirinha e agora estamos aproveitando a tarde na praça. Meu filho está correndo dentro do coreto encantado.” Ao ser questionado pela acessibilidade pública na praça, o entrevistado disse que recebeu orientações no hotel e acompanhou a sinalização. Relatou que, ao tomar café no comércio do entorno, teve acesso a programação de músicas e recreações. Na dimensão da legibilidade, lembrou de alguns momentos da infância na praça do bairro onde morava e fez algumas comparações com o local em que estava “... brincava com meus amigos na praça do bairro. A gente andava de bicicleta e tomava sorvete... Aqui em São Pedro as praças são muito parecidas, bancos, grandes árvores, crianças brincando. Realmente me faz lembrar da infância”. Quanto a identidade, o turista afirmou que não conhece muito sobre a história local e que não encontrou nenhuma informação no entorno, uma vez que o Museu já estava fechado. Mas a cultura de cidade pequena onde as pessoas de diversas idades conversam e a gastronomia típica caipira estão presentes dentro e no entorno da praça.

A terceira turista entrevistada possui trinta e três anos de idade, mora em Piracicaba e estava acompanhada do marido e do filho. A entrevista foi realizada na praça, em um final de tarde de um domingo do mês de novembro, momentos antes da família retornar à cidade de origem. A conversa durou, aproximadamente, trinta e cinco minutos e foi registrada em um aparelho telefônico móvel. A jovem vem a São Pedro, no mínimo, uma vez ao mês e se hospeda na casa da cunhada. Todas as vezes que está na cidade passa pela praça, pois o filho é acostumado a brincar em parques e praças onde mora. O local do estudo a motiva pelo lazer que proporciona à família "meu filho corre por todos os caminhos; pula nos bancos; sobe no coreto e adora comer pipoca. Nós recarregamos as energias brincando com ele aqui”. Falando 
sobre a acessibilidade, a entrevistada nota a chegada de turistas por meio de carros e ônibus de excursões sem dificuldade; recebe informações sobre eventos por meio da página da cidade em redes sociais, mas a acessibilidade de deficientes físicos é um ponto negativo "as rampas de acesso, nas esquinas, estão com o concreto quebrado e os cadeirantes têm dificuldades para entrar na praça. $\mathrm{O}$ piso tátil, para deficientes visuais, está em bons caminhos, mas existem degraus entre eles". Para a dimensão da legibilidade, constata que as praças que sempre visitou são semelhantes nos aspectos físicos e humanos. Árvores em meio a cidade; diversos tipos de flores; pessoas descansando em sombras; convivência entre moradores e visitantes. Referindo-se a identidade, o busto do poeta que dá nome a praça, Gustavo Teixeira, é citado como maior referência da cultural local. As músicas e as peças teatrais são mencionadas na sequência. Outro destaque relatado é a festa do padroeiro São Pedro que é realizada na Praça e na Praça da Matriz.

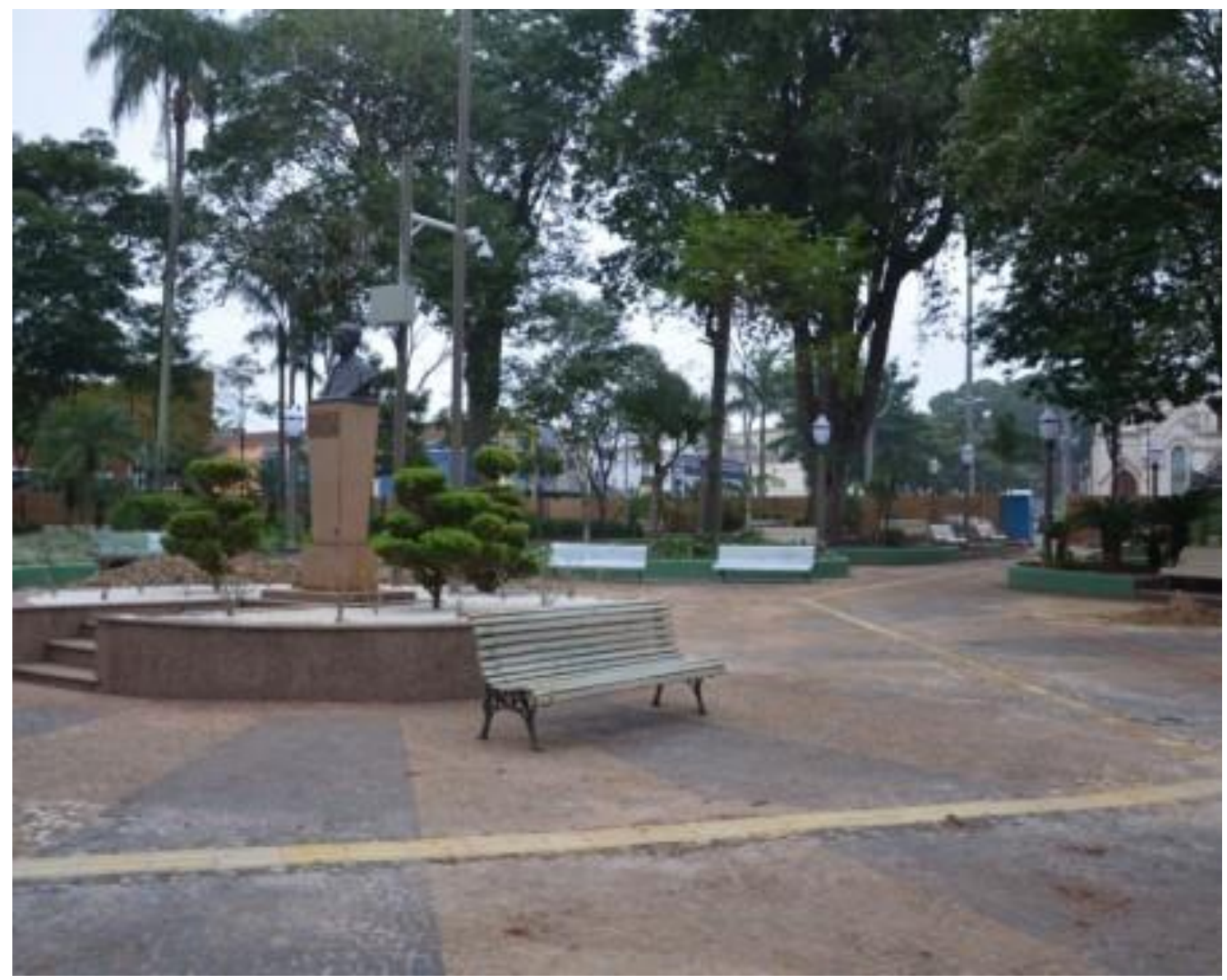

Figura 23 - Piso tátil

Fonte: Arquivo Prefeitura Municipal de São Pedro 
A quarta visitante entrevistada é uma mulher, de quarenta e seis anos de idade, que reside na cidade de Piracicaba. A visitante frequenta a cidade, por ser jornalista, com o objetivo de turismo de negócios, e constantemente está em atividades externas. A conversa para a coleta das informações durou vinte e cinco minutos, se deu em um dia de semana, do mês de abril, próxima a Igreja Matriz. A visitante não frequenta a praça constantemente, a não ser que a mesma esteja próxima a seu trabalho e/ou ao término dele, consiga usufruir de sua estrutura. A motivação de parar e descansar se dá pela estrutura, pelas áreas arborizadas e, principalmente, pela sensação de segurança "gosto de observar como as pessoas interagem e conversam entre si. Em minha cidade a maior parte das praças é vazia e violenta. Por estar em São Pedro em dias de semana percebo crianças fazendo atividades escolares, idosos passeando com seus familiares e isso me dá uma sensação de aconchego". Ao ser questionada sobre a acessibilidade local, diz que a pavimentação das ruas, a localização no centro da cidade, a proximidade com a Igreja Matriz (marco inicial das cidades do interior) são pontos positivos. Quanto a acessibilidade de informações, afirma ler matérias sobre atividades realizadas tanto em jornais impressos quanto em mídias digitais. Ao falar sobre a dimensão da legibilidade, enfatiza que os bancos, o coreto, as plantas e árvores, o fluxo de pessoas a fazem associar o local com praças de outras cidades que estão presentes em seu dia-a-dia. Por fim, a identidade é mencionada quando fala sobre o comércio do entorno, sobre o Museu e sobre atividades escolares que resgatam leituras e poesias.

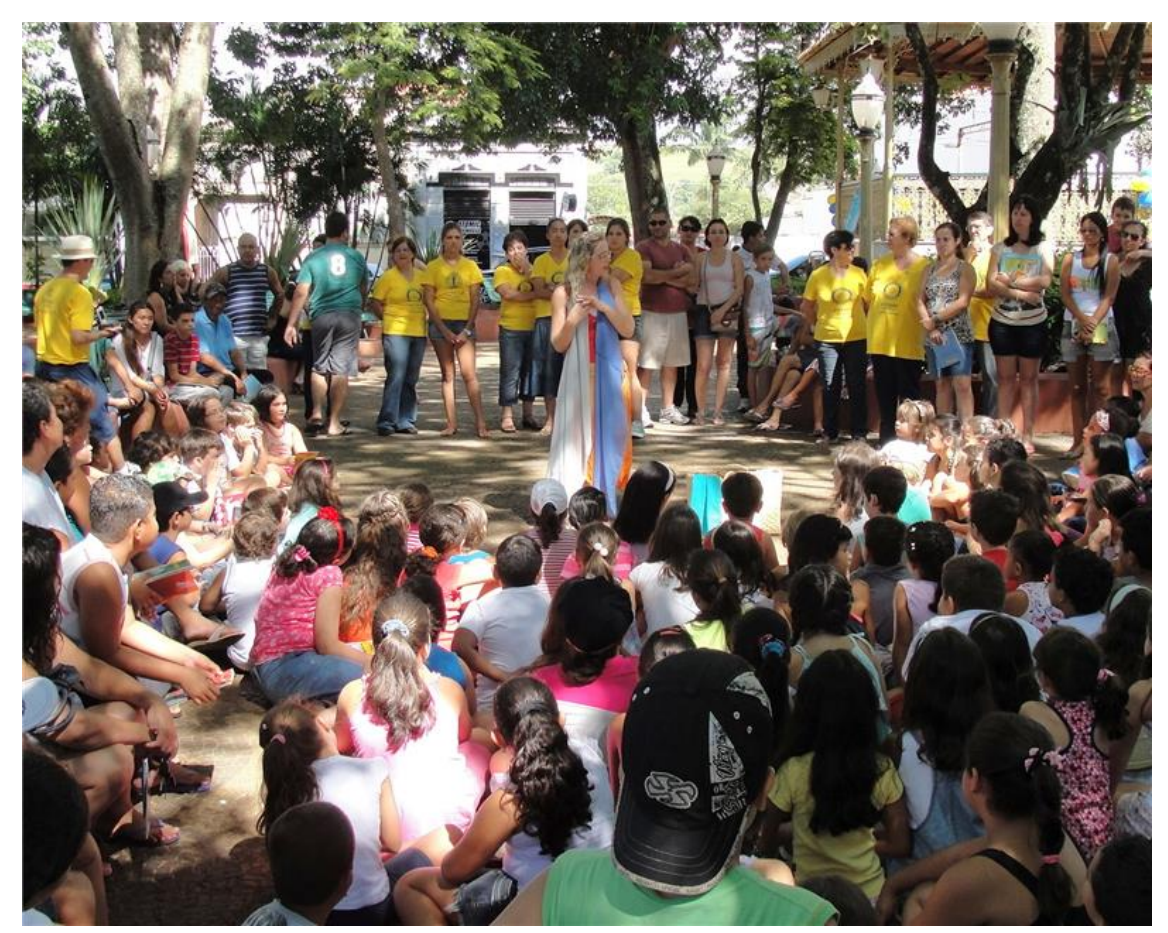

Figura 24 - Projeto Leitura na Praça

Fonte: Arquivo Prefeitura Municipal de São Pedro 
A quinta turista entrevistada possui quarenta e quatro anos, mora na cidade de São Paulo e estava acompanhada de seu marido e de seus cachorros. A conversa foi realizada no entorno da praça, em um domingo do mês de abril, teve duração de vinte minutos e foi registrada em um caderno de anotações. A visitante frequenta a cidade constantemente motivada pela fuga da correria e do estresse da cidade grande, possui uma casa de veraneio na Estância e, sempre que possível, passeia pelo centro. Acredita que a praça é acolhedora pelo simples fato dos moradores conversarem constantemente com pessoas que não conhecem e, no decorrer da conversa, acabarem falando sobre a vida: "sempre que venho à praça trago meus cachorros para passear e isso atrai a atenção das pessoas. Elas se aproximam, brincam com eles e, consequentemente, iniciamos uma conversa. Isso dura horas e não tem dinheiro que pague. Nunca que isso acontece em São Paulo”. Ao ser questionada sobre a dimensão da acessibilidade, a entrevistada diz que tudo é perto da praça e isso é bom. Na cidade em que mora tudo é longe e o trânsito atrapalha o deslocamento. Sobre a legibilidade, compara o local com praças da capital: "aqui vejo uma praça igual as da minha infância, com coreto, bancos e pessoas se divertindo. Em São Paulo tudo está descaracterizado, sem cor, sem vida. Sem contar a violência". Por fim, a identidade é notada no comércio do entorno e no relacionamento que as pessoas têm umas com as outras, típico de cidade do interior.

O sexto e último entrevistado possui quarenta e seis anos, reside na cidade de São Paulo e é instrutor de voo livre. O turista frequenta o objeto de estudo semanalmente, pois tem família na cidade, além de uma casa de veraneio. A entrevista foi realizada em um sábado do mês de abril, durante um passeio no comércio do centro. Diversas são as motivações que o levam a visitar a praça, estando entre elas o comércio gastronômico do entorno; os eventos como carnaval, São Pedro Adventure e Música na Praça, além das recordações afetivas da infância vivida na cidade. O piloto acredita que o acolhimento existe no centro da cidade, bem como relações entre moradores e anfitriões: “quando criança, corria e brincava com meus primos nos caminhos da Praça. Crianças que não conhecia entravam na brincadeira e nosso grupo crescia. Hoje, percebo que moradores conversam comigo e com minha família quando tomamos sorvete, comemos pipoca. Essa relação é estabelecida mesmo sendo adulto”. 


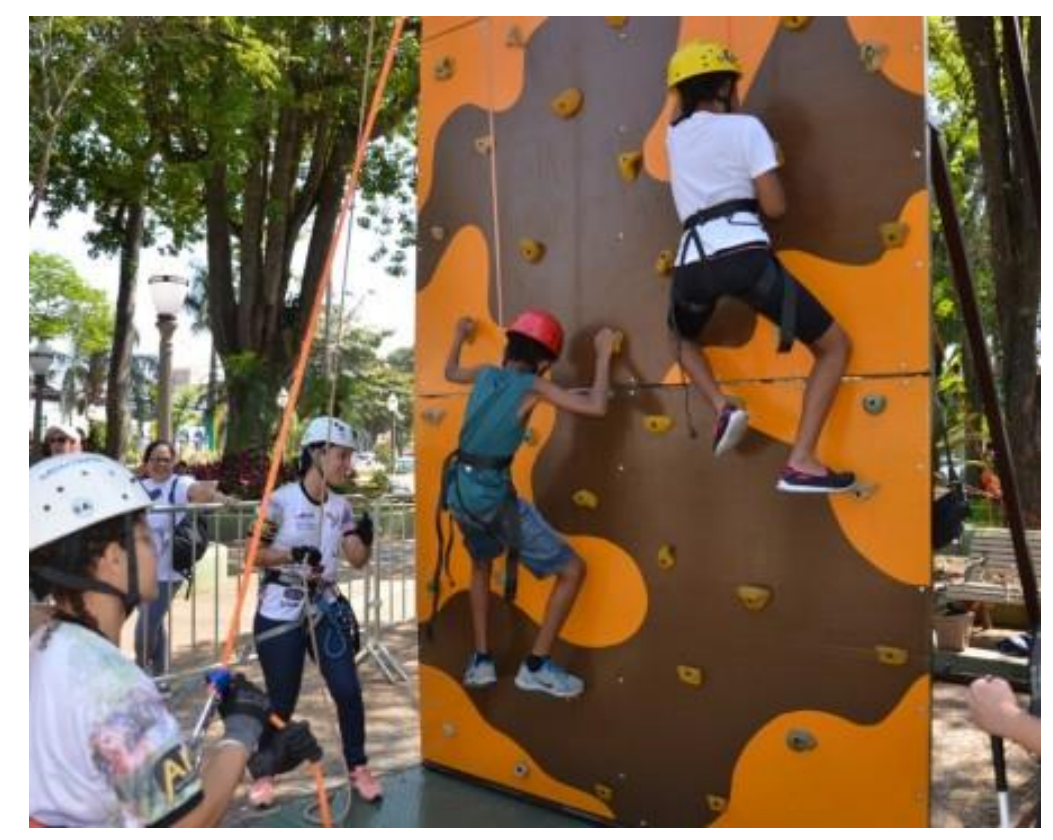

Figura 25 - Evento Aventura na Praça

Fonte: Arquivo Prefeitura Municipal de São Pedro

Ao conversar sobre acessibilidade, o visitante diz que chega até o local com carro, sem dificuldade, mas sente falta de sinalização turística. Porém, ao fazer o mesmo trajeto a pé, percebe que as calçadas não estão em condições perfeitas. Quanto ao acesso as atividades realizadas no local do estudo, acredita existir, pois as entradas são gratuitas e os temas são atrativos, porém percebe que a linha de transporte público não facilita a chegada. Já a legibilidade é perceptível pelo vasto espaço arborizado; pela brisa; pelo coreto; por estar localizada próxima a Igreja Matriz, típico de cidade do interior. Por fim, a identidade se faz nítida nas características de uma cidade pequena encontrada na praça, como relação entre as pessoas, segurança durante as atividades realizadas, acolhimento dos anfitriões.

O primeiro morador entrevistado possui trinta anos, nasceu e reside no município de São Pedro SP e faz parte da família do fundador da cidade - tataraneto. A conversa aconteceu em sua residência, pois a família estava presente e contribuiu com os relatos e as informações. Com duração de uma hora e trinta minutos, a entrevista foi realizada em um dia de semana do mês de dezembro e teve seu registro em um caderno de anotações e em um aparelho telefônico móvel. O morador visita a Praça todos os dias, pelos mais diversos motivos: faz parte do caminho para o trabalho, lazer, degustação gastronômica e atividades profissionais. Durante o período de trabalho, seu envolvimento consiste na organização e realização de eventos culturais com foco no morador e no turista: Festa de São Pedro; Carnaval; Música na Praça; Apresentações Teatrais. 


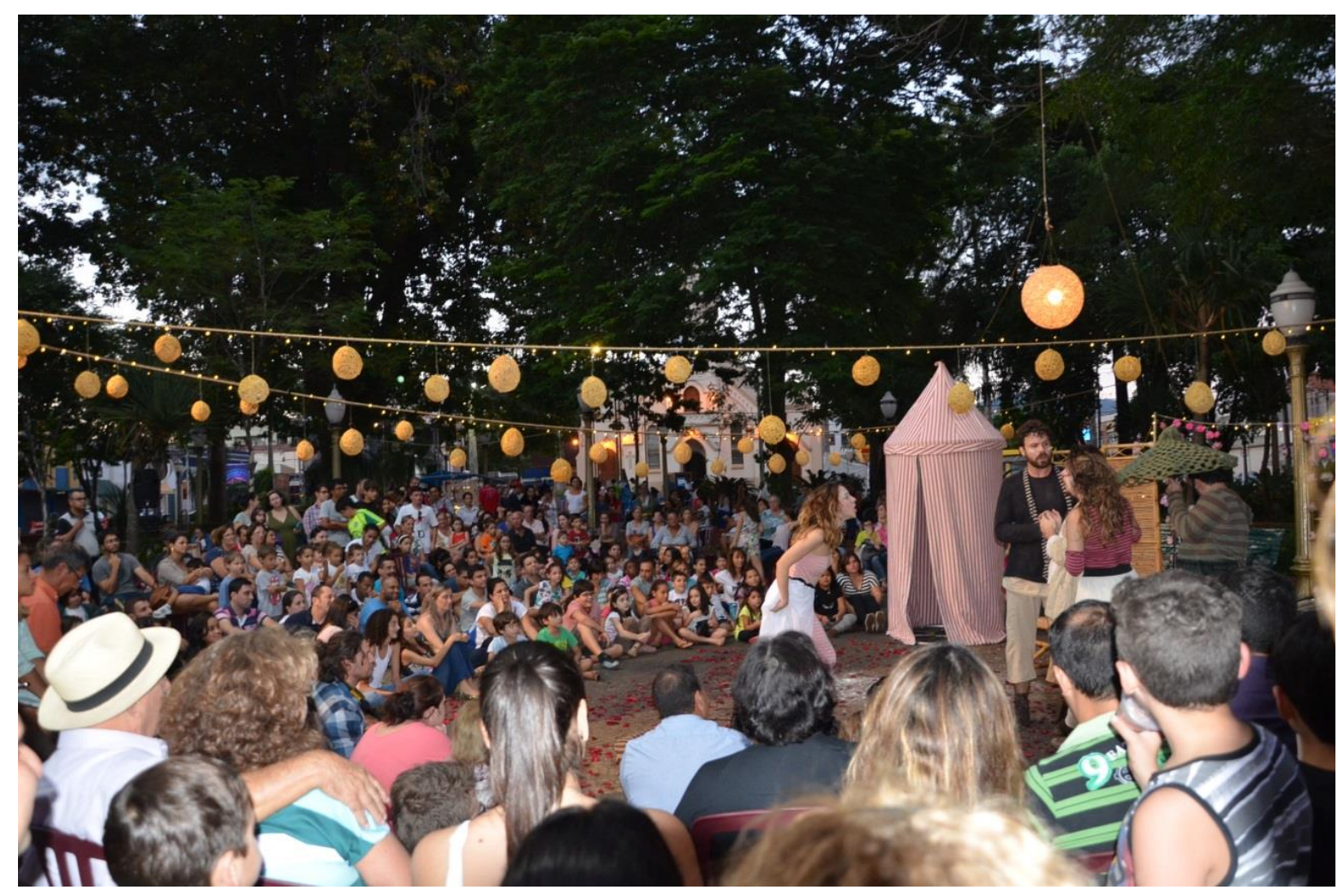

Figura 26 - Apresentação Teatral - Circuito de Artes Sesc 2016 Fonte: Arquivo Prefeitura Municipal de São Pedro.

Quanto ao acolhimento, o entrevistado acredita que as características de "praça do interior” fazem a diferença “... a beleza, o carinho... O acolhimento faz parte de sua concepção, que surge da necessidade de um grupo de jovens em se reunir. Um espaço para o encontro de pessoas... Por mais que você esteja sentado sozinho, as pessoas passam, te dão bom dia e param para conversar". A partir dessa fala nota-se o estabelecimento de uma relação entre anfitriões e, posteriormente, entre anfitriões e turistas "o pessoal de fora ao perceber que você é morador da cidade faz perguntas como: vai ter apresentação na Praça? Você indica um ponto turístico? Sempre tem uma relação e dali pode gerar uma amizade. É muito gostoso o envolvimento que a Praça gera". Ao refletir sobre o espaço físico, acessibilidade, enumera características como: pontos de ônibus e táxi no entorno, placas de informações desde a entrada da cidade, a torre da Igreja que é avistada desde o portal principal, as atividades realizadas no local são gratuitas e isso possibilita o acesso dos moradores, a divulgação é feita em canais de comunicação digitais, rádios, impressos, boca a boca "até divulgação volante, que é o corriqueiro, o que mais esperam, ainda existe". A legibilidade foi abordada de forma sucinta, iniciando-se pela figura do coreto, passando pelo amplo espaço para atividades, jardins floridos, áreas arborizadas e com sombras, e área verde em meio ao urbano. Por fim, a dimensão da identidade possui falas envolvidas com sentimento. O comércio do entorno, com bordados e ponto cruz; o Museu Gustavo Teixeira, 
que retrata a história da cidade e a vida do poeta; a Biblioteca Municipal, que também recebe o nome do poeta; a Feira de Artesanato, com artesanato e peças de produção manual; as lojas que comercializam doces caseiros, inclusive o Jaracatiá são citados no decorrer da conversa sobre identidade. A Praça como cenário de inspiração para artistas plásticos, que produzem e expõem seus trabalhos, como antigamente com o Poeta também é relatada. E, finalizando, a Praça como palco de homenagens a Gustavo Teixeira por meio de atividades pedagógicas promovidas pela Secretaria de Educação e pela Coordenadoria de Cultura - "Semana Literária Gustavo Teixeira”. “...os alunos propagam as poesias do poeta na atividade da Voltinha Literária; eles fazem declamação e entregam flores em homenagem em nome do poeta das flores na herma localizada no centro da Praça".

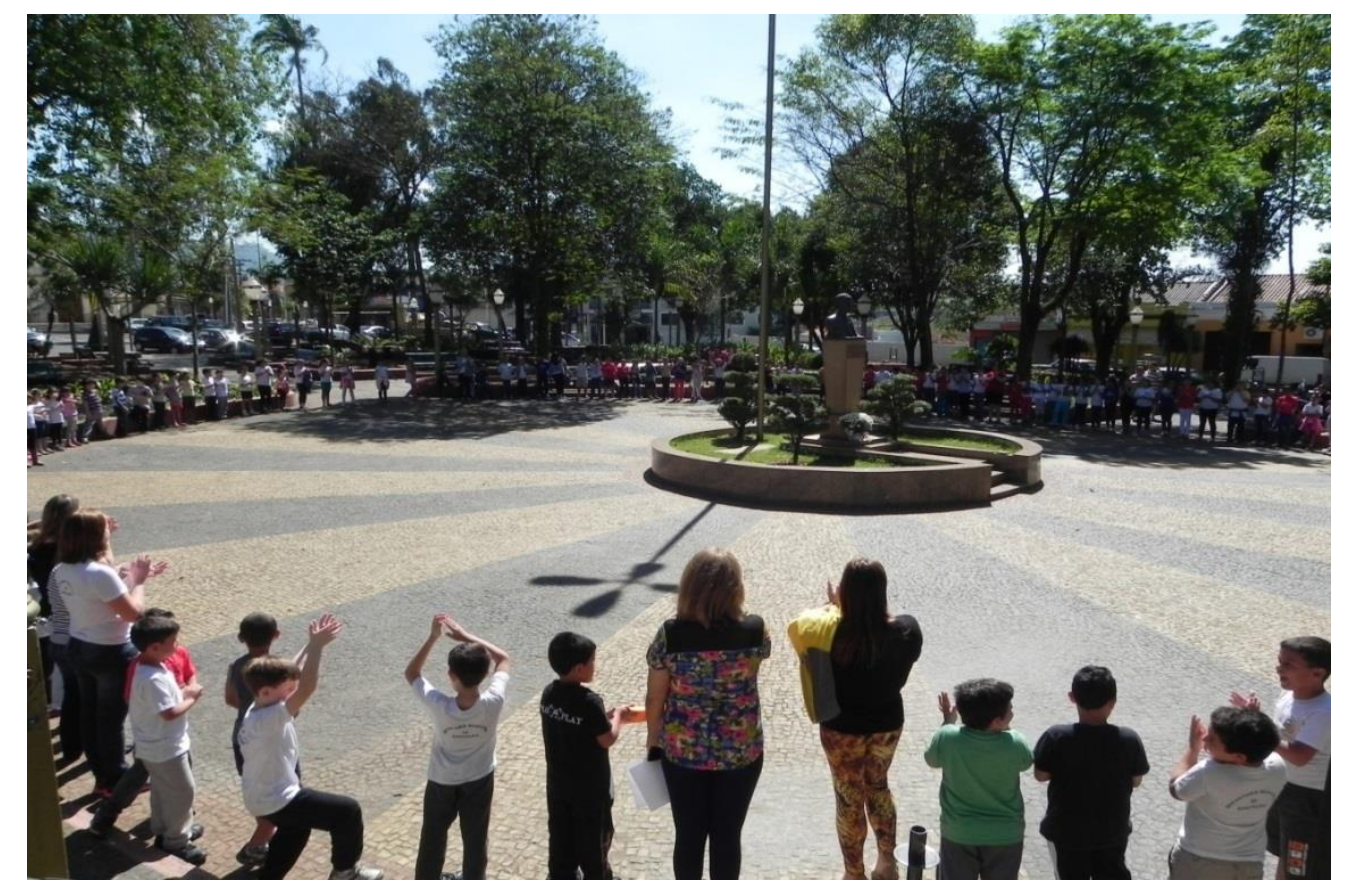

Figura 27 - Semana Literária Gustavo Teixeira - 2016

Fonte: Arquivo Prefeitura Municipal de São Pedro

A segunda moradora entrevistada é uma senhora de sessenta e oito anos, que nasceu e reside no município de São Pedro, e atua como professora na rede municipal de ensino. A anfitriã concedeu a entrevista na escola municipal em que trabalha, ao término de sua aula, em um dia de semana do mês de novembro. Durante a uma hora de conversa, as memórias e os relatos foram armazenados em um aparelho telefônico móvel. A moradora passa pela Praça diariamente, pois é caminho para seu trabalho. Porém, não soube quantificar quantas vezes usufrui do espaço no decorrer da semana, pois todas as vezes que passa pelo local senta, descansa, toma sorvete. Ao falar sobre a motivação de visitar a Praça explica: "é uma coisa de coração, mesmo. Ai que gostoso sentar na praça; motivação de lembrança; de recordação... 
Quando sento na Praça, essa Praça é cheia de memória, memórias de quando tinha oito anos; de quando ia à escola; ia à missa... É recordação; é memória; é recordação das pessoas". Referente ao acolhimento, afirma ser aconchegante sentar, pois tem uma brisa gostosa, tem cheiro de pipoca, tem memória. Recordou-se, ainda, dos antigos footings “... outro dia eu fui caminhar e comecei a andar por fora porque a volta é maior. De repente fui para dentro, comecei a andar dentro e pensei: por que será que estou andando aqui se lá fora a volta é maior? Me peguei pensando que no meu tempo não podia andar por fora da praça porque moça direita não andava por fora... Não podia, mas a gente queria. Os moços bonitos ficavam todos lá”. Relata ainda que ao passear pelo local nota-se um contato amigável entre os moradores, uma relação segura com pessoas conhecidas, existem conversas com pessoas que estão sentadas próximas. “Às vezes estamos passando pela Praça e uma pessoa pergunta que horas são. A gente diz a hora e inicia uma conversa informal”. Em se tratando dos visitantes, os mesmos estabelecem uma interação com os anfitriões “...a praça tem essa coisa de que é um lugar bom, que pode parar para conversar, pois não vai acontecer nada... Por exemplo, uma família vem de São Paulo e deixa as crianças brincarem na Praça! Não fazem isso em São Paulo... Ali é um lugar acolhedor... As pessoas se sentem seguras...”.

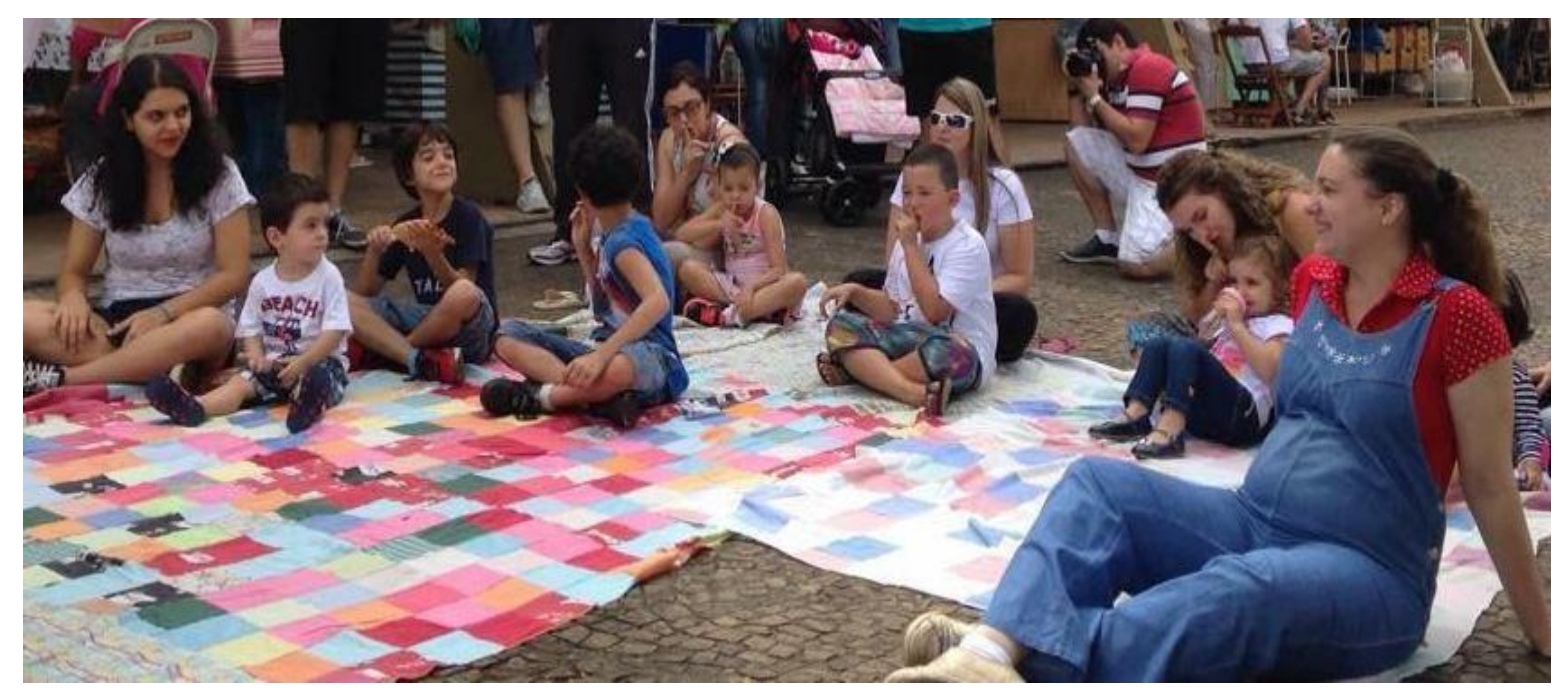

Figura 28 - Atividade Contação - 2015

Fonte: Arquivo Prefeitura Municipal de São Pedro 


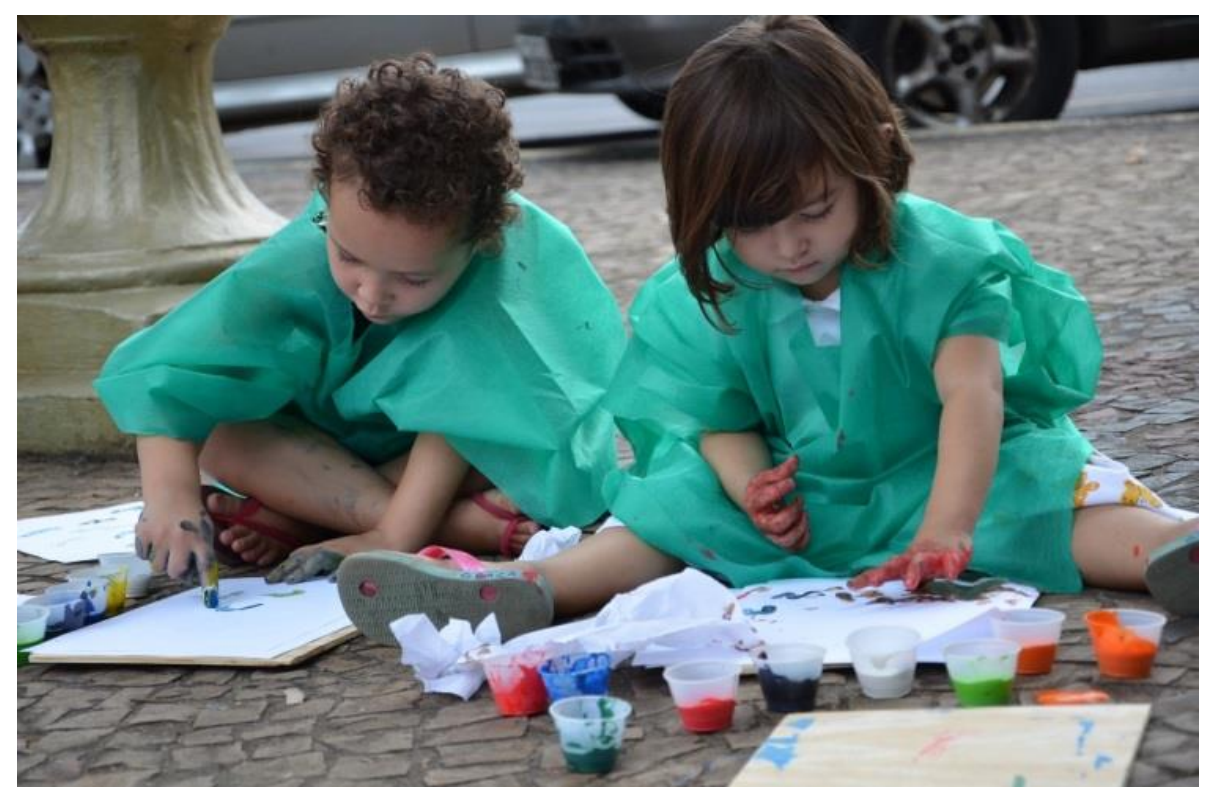

Figura 29 - Atividade Pintura na Praça - 2015

Fonte: Arquivo Prefeitura Municipal de São Pedro

Ao ser questionada sobre acessibilidade, a entrevistada afirma que é acessível quanto caminho, pois a maior parte dos bairros possui ligação com o centro da cidade. Porém, acesso a informações referentes às atividades desenvolvidas acredita não ser positivo, uma vez que a população não está habituada a ler jornal ou acessar sites a fim de buscar esse tipo de notícia. Cogitou a possibilidade de uma divulgação mais frequente em carros volantes, pois são tradicionais tanto quanto alto-falantes. Para a dimensão da legibilidade, bancos, pássaros, sombras de árvores, som do vento proporcionam a sensação de estar em uma praça. Por fim, enquanto identidade, o local mantém viva a história da cidade "eventos, Festa de São Pedro, procissão... Quando sabemos que está tendo um evento em outro lugar perguntamos o motivo de não estar acontecendo na Praça... Essa música na praça é muito gostosa porque tínhamos a Banda do Zeca Turco que tocava antigamente".

A terceira anfitriã entrevistada é uma senhora de setenta e cinco anos, que nasceu na cidade vizinha de Santa Maria da Serra e hoje reside em São Pedro. As memórias e as informações foram recebidas no banco em frente a doceria, na manhã de um sábado do mês de dezembro. A conversa teve duração de cinquenta minutos e o seu término se deu no meio da praça, uma vez que o convite para um passeio foi feito pela moradora. A entrevistada possui um comércio no entorno da Praça e, dessa forma, faz uso diário de seu espaço. A motivação que a leva a frequentar o local de estudo é, inicialmente, comercial “... a maior parte dos turistas que está no centro da cidade frequenta minha doceria. Eles tomam café e depois vão sentar embaixo das árvores". Porém, ao lembrar-se de sua adolescência, a motivação é outra "frequento a Praça há mais de cinquenta anos. Passeava sempre com 
minhas amigas. Era comum fazermos passeios no clube e no Hotel Central que ficava ao lado da praça. Esse lugar é lindo e quando fico aqui relembro de todos esses momentos da vida".

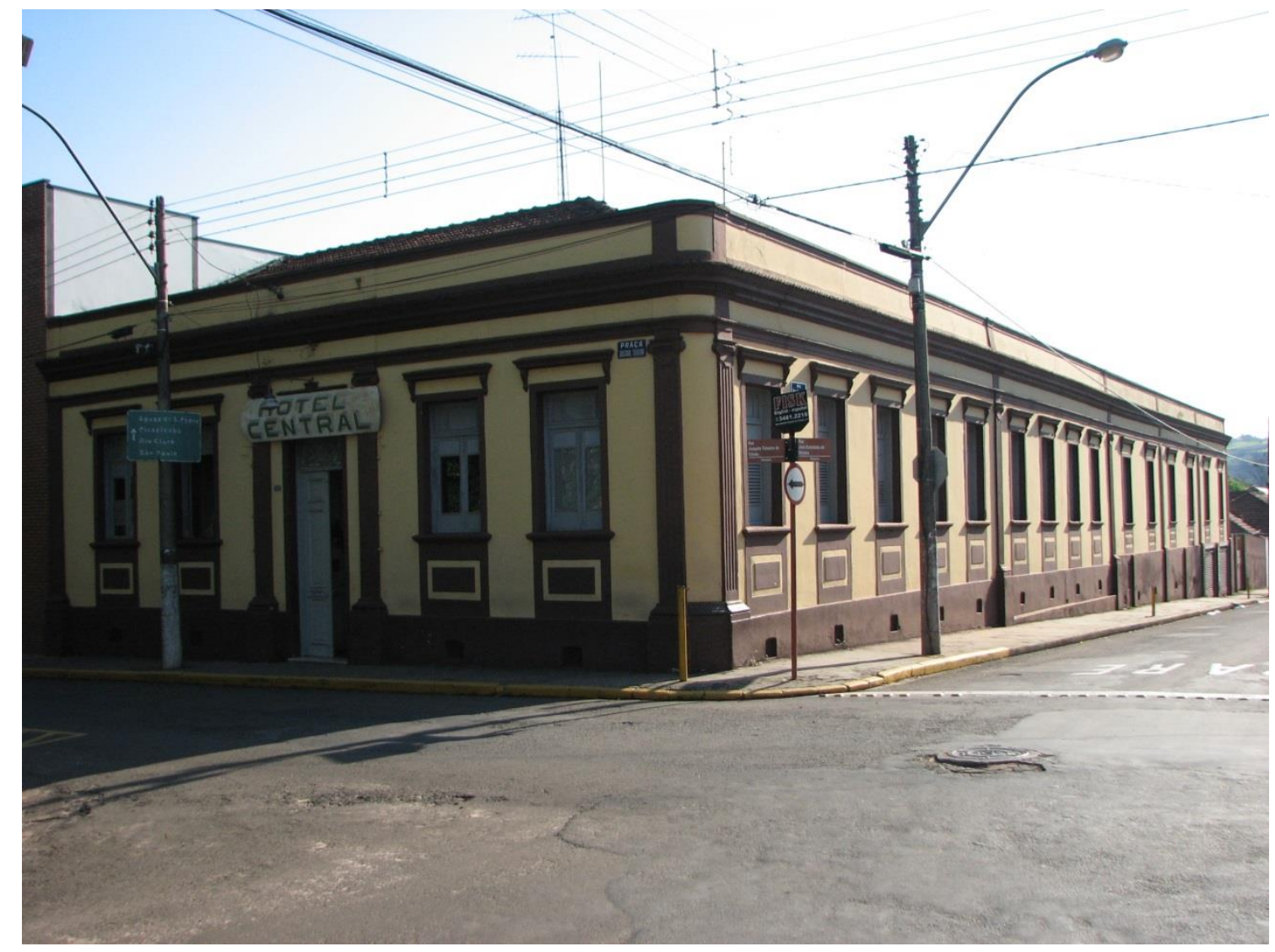

Figura 30 - Hotel Central - década de 1980

Fonte: Arquivo Prefeitura Municipal de São Pedro

Sobre a relação entre moradores, a entrevistada afirma existir entre as mais diferentes idades, durante todo o dia e nas mais diversas situações "muitos pais trazem seus filhos para brincar de bicicleta, de bola, de corre-corre. É normal encontrar famílias amigas e assim o papo vai longe”. Já com os visitantes, o que mais identifica são perguntas e comentários sobre a cidade dentro de seu estabelecimento, com suas colaboradoras e moradores que lá estão. Ao referir-se sobre a dimensão da acessibilidade, a moradora diz receber clientes locais dos mais diversos bairros e após comerem em sua loja passeiam pela Praça. Os turistas encontram o local com facilidade e têm facilidade ao acesso com ruas asfaltadas e lugares para estacionar. Porém, em relação às atividades desenvolvidas, acredita que muitos anfitriões não possuem acesso as informações "precisamos pensar em novas atividades que chamem atenção da população porque a Praça já foi um lugar mais movimentado. Muitos clientes chegam para pegar informações na doceria ou ligam porque não encontram; outros perguntam depois que 
já aconteceu". Em relação a legibilidade, o objeto de estudo caracteriza-se como praça com arborização, coreto, bancos, espaços para descanso "a praça é linda. Criei minhas filhas aqui. Uma delas saia correndo nos caminhos e eu só via sua cabecinha por cima dos arbustos. Mas, acho que hoje ela está abandonada. Precisam podar as plantas que estão altas. As vezes sento no banco em frente a loja e não enxergo seu centro. O prefeito precisa contratar um jardineiro que cuide dela com carinho. Alguns turistas falam que adoram aqui, mas sentem que precisa melhorar". Finalizando a conversa, a senhora disse perceber a cultura do São-Pedrense ao participar das atividades musicais e infantis, pois várias gerações estão no local e assim a história se perpetua.

Ao entrevistar a quarta pessoa, constatou-se que trata-se de uma mulher com trinta e nove anos de idade, natural de São Pedro, funcionária pública. A troca de informações e conhecimento aconteceu em uma outra praça da cidade, em uma tarde de domingo do mês de abril, teve duração de cinquenta minutos e tudo foi registrado em um aparelho telefônico móvel. As visitas ao local do estudo acontecem esporadicamente, pois as atividades relacionadas a lazer durante a infância e a juventude aconteceram na praça Santa Cruz devido a proximidade com sua antiga residência. As motivações, hoje, são as mais diversas: eventos esportivos e culturais; passear em um lugar aconchegante e arborizado: "o aconchegante é encontrar famílias sentadas nos bancos e, em alguns momentos, bancos que sentavam quando criança. Isso remete a momentos da infância. Aliás, quando criança minha mãe me levava no centro para comer pipoca do Sr. Afonso, que era o pipoqueiro na época (risos). Era um evento ir à praça comer pipoca. Nós entendíamos que ir à Praça Gustavo Teixeira era para pessoas ricas, pessoas que eram sócias do clube". Outra motivação, hoje, é levar os filhos para ver as pombinhas, brincar com os amigos no coreto, proporcionar a eles o que teve quando pequena. Quanto a relação entre anfitriões e turistas, a moradora não percebe com tanta frequência e acredita que deveria ser diferente, pois o município é uma Estância Turística e o receber deveria ser melhor trabalhado. Já o relacionamento entre são-pedrenses é notado de maneira mais nítida: "eu sou bicho do mato, admito. Mas, quando sou recebida dessa forma, adoro. Quem não gosta? Eu vejo isso entre os moradores sim, famílias que se conhecem há muitos anos, sentam e colocam a conversa em dia. Mesmo não fazendo isso, observo”. Ao ser questionada sobre acessibilidade, afirma que o local é de fácil acesso por estar no centro da cidade, mas precisa melhorar em questão de sinalização turística, transporte público e número de vagas para estacionamento. Pontos de táxi, estado de conservação das vias e sua sinalização horizontal (pintura de guias e vagas de estacionamento), divulgação das atividades são pontos positivos. Já a dimensão da legibilidade possui itens que fazem com que os 
moradores a reconheçam como praça. Sombra, árvores, tranquilidade foram citados: "poderia ser aprimorada enquanto praça. Me veio a cabeça o projeto paisagístico apresentado à população no ano de 2014. Muitos espaços foram desenhados e fizeram sentido, complementariam o que já existe".

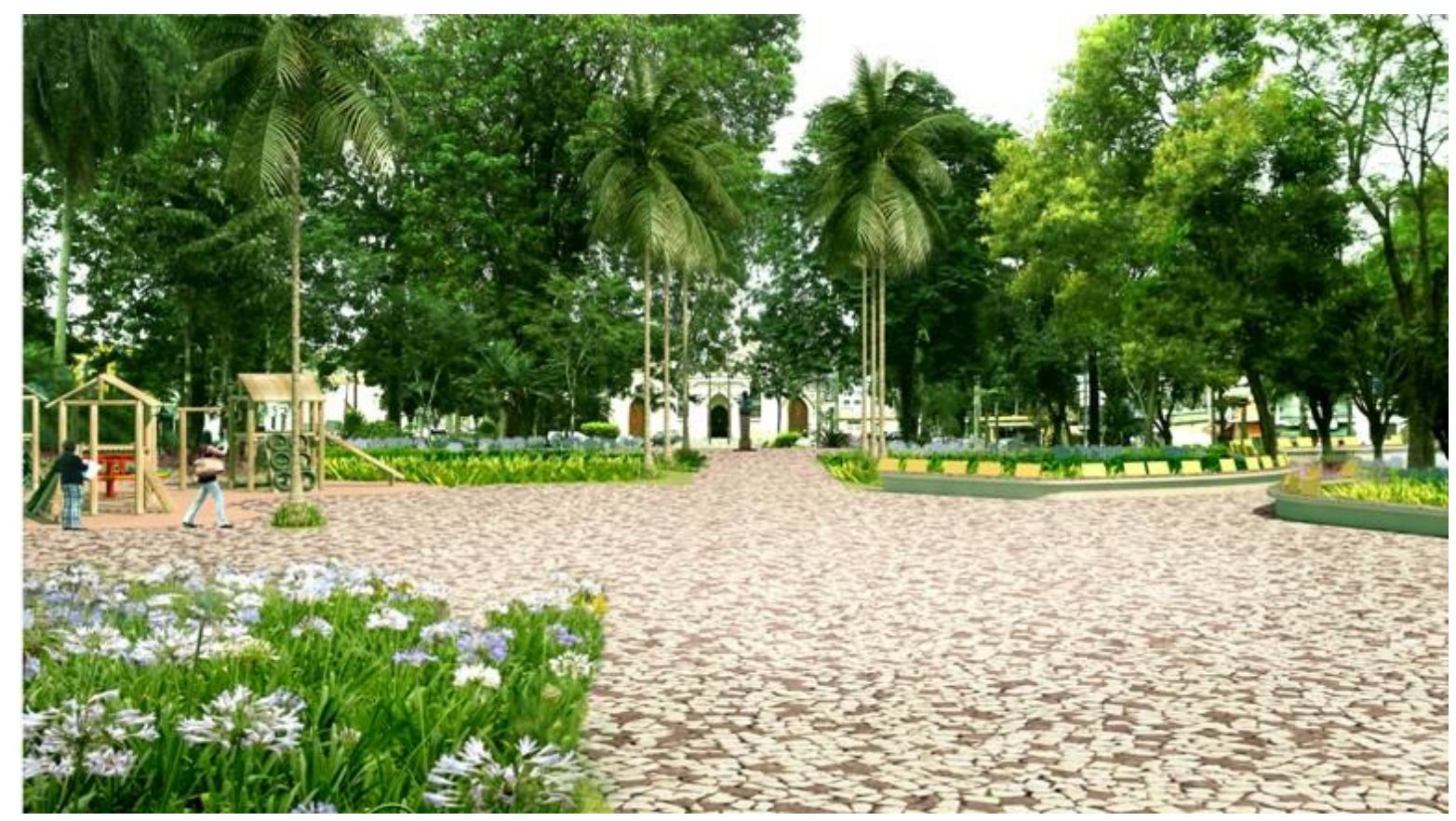

Figura 31 - Esboço projeto vencedor concurso paisagístico

Fonte: Arquivo Prefeitura Municipal de São Pedro

Ao finalizar a entrevista, a dimensão da identidade foi abordada. O frequentar a praça como momento de lazer da família passa de pai para filho como tradição cultural; o comércio do entorno, com a comercialização do bordado e dos enxovais e a doceria da Zuleika; a Feira de Artes e Artesanato; o Museu Gustavo Teixeira representam a história da Estância. Porém, em alguns momentos, a entrevistada afirma que nem sempre o objeto de estudo é a motivação principal para a visitação, uma vez que percebe que, por exemplo, tomar um sorvete é o objetivo e visitar a praça é secundário.

A quinta moradora entrevistada é uma mulher de cinquenta e cinco anos de idade; nascida e moradora do município; funcionária pública - Guarda Civil Municipal. A entrevista foi realizada em uma manhã de domingo, no mês de abril, na Praça Gustavo Teixeira, e teve duração de quinze minutos. Todas as informações foram anotadas em um caderno. Hoje, a anfitriã visita a praça constantemente, em momentos de trabalho e em momentos familiares. Disse observar interação entre moradores e turistas, com mais frequência aos finais de semana, e entre os são-pedrenses diariamente, principalmente entre idosos e famílias 
conhecidas. Ao recordar de sua infância, os passeios eram raros, pois ela e os pais moravam em uma fazenda distante da cidade: "lembro que vínhamos para cidade com pouca frequência e passávamos pelo centro só para ir ao terminal rodoviário, que na época era atrás da Igreja Matriz". Durante a entrevista, a moradora deixou claro que a acessibilidade existe no local do estudo no que tange as vias públicas de acesso, uma vez que seus turnos de trabalho são em grande maioria na região central e consegue observar as chegadas e as partidas. Diversos são os turistas que chegam com veículos próprios ou com ônibus de excursão e poucos os que chegam por meio de táxi. Porém, algumas melhorias precisam acontecer no que tange o acesso aos portadores de deficiência física. Já a dimensão da legibilidade se faz perceptível por moradores e visitantes. Muitas são as semelhanças notadas e comentadas se comparadas com as praças que frequentam em outras cidades ou em outras regiões da própria Estância. Os itens mais citados são o coreto, os bancos e a grande área arborizada. Finalizando, a identidade é notada na tranquilidade de uma cidade do interior, na feira de artesanato do Boulevard (que localiza-se atrás da Igreja Matriz) e no comércio do entorno.

Por fim, a última entrevistada é uma empresária da área gastronômica, com trinta e cinco anos de idade, são-pedrense. A entrevista aconteceu em um dia da semana, após uma reunião do Conselho Municipal de Turismo, no mês de abril, tendo quinze minutos de duração. As informações e os relatos foram registrados em um aparelho telefônico móvel. A moradora frequenta a praça diariamente, pois mora no entorno. As visitas são motivadas pelas atividades culturais e esportivas realizadas no espaço da praça; pelo prazer de levar as filhas andar de bicicleta nos caminhos internos; para tomar um café na doceria que localiza-se no entorno ou pelo simples fato de sentar num banco após fazer atividade física no clube. A entrevistada afirma que a praça é acolhedora em diversos fatores como o formato dos bancos, arborização e relação entre as pessoas. Quanto aos relacionamentos estabelecidos no espaço, diz perceber durante as ações entre famílias e no momento em que informações são passadas aos turistas. Ao ser questionada sobre a dimensão da acessibilidade, acredita ser acessível devido a sua localização no centro da cidade, por estar no caminho de outros atrativos turísticos, porém essa localização deixou de ser tão privilegiada para o morador no momento em que alguns bancos e alguns comércios migraram para outra praça - Praça Santa Cruz. Já a dimensão da legibilidade faz-se presente nos jardins, nos bancos, no coreto. Por fim, a identidade é perceptível no busto do poeta Gustavo Teixeira, na tranquilidade de uma cidade do interior, no comércio do entorno (lojas de bordados e enxovais). 
Com o término das pesquisas, uma análise acerca dos depoimentos dos anfitriões e dos visitantes se fez possível. Falas e lembranças repletas de sentimento, tanto pela Praça do estudo quanto pelas praças frequentadas no decorrer da vida, tornaram-se nítidas.

Moradores com moradores; moradores com turistas; turistas com turistas interagiram a todo momento, tanto no interior da praça quanto em seu entorno. Durante a interação, as dimensões inseridas no contexto da hospitalidade pública se fizeram presentes. E, em vários momentos, tornaram esse relacionamento possível.

HOSPITALIDADE PUBLICA: PRAÇA GUSTAVO TEIXEIRA

\begin{tabular}{|c|c|c|}
\hline QUESTÕES NORTEADORAS & VISÃO MORADOR & VISÃO TURISTA \\
\hline \multirow{5}{*}{ Motivação para visita } & Lazer & Lazer \\
\hline & Bem-estar & Descanso \\
\hline & Trabalho & Trabalho \\
\hline & Recordações & Memórias da infäncia \\
\hline & Pertencimento & Memórias cidade de origem \\
\hline \multirow{4}{*}{ Relação entre moradores e turistas } & Encontro entre familias & Informações \\
\hline & Encontro entre amigos & Acolhimento \\
\hline & Informações para turistas & Não somente na praça \\
\hline & & Bom atendimento no comércio do entorno \\
\hline \multirow{5}{*}{ Dimensão Acessibilidade } & Ruas pavimentadas & Qualidade do asfalto \\
\hline & Sinalização & Ponto de táxi no entorno \\
\hline & Localização no centro da cidade & Localização no centro da cidade \\
\hline & \begin{tabular}{|l|} 
Ponto táxi no entorno \\
\end{tabular} & Acessibilidade para deficiente fisico a melhorar \\
\hline & Acessibilidade intangivel melhorar & Acessibilidade intangivel positiva \\
\hline \multirow{6}{*}{ Dimensão Legibilidade } & Coreto & Coreto \\
\hline & Bancos & Bancos \\
\hline & Arborização & Arborização \\
\hline & Espaço verde em meio ao urbano & Localização no centro da cidade \\
\hline & Espaço para lazer e recreação & Brincadeiras entre crianças \\
\hline & Manutenção paisagistica a melhorar & Encontro com amigos \\
\hline \multirow{4}{*}{ Dimensão Identidade } & Relatos de vida - pertencimento & Comércio do entorno: artesanato, bordado \\
\hline & Caracteristicas de cidade do interior & Caracteristicas de cidade do interior \\
\hline & Atividades artisticas & Atividades artiticas \\
\hline & Busto e atividades sobre o Poeta & \\
\hline
\end{tabular}

Figura 32 - Quadro Resumo

Fonte: Própria autora 
O quadro acima resume as respostas dos grupos analisados no decorrer da pesquisa. Visões, percepções, sentimentos e lembranças se assemelham em determinados momentos. Pontos positivos e negativos existem em ambos os grupos. Porém, todos afirmar existir hospitalidade na Praça Gustavo Teixeira. 


\section{CONSIDERAÇÕES FINAIS}

Tendo o turismo se fortalecido como uma das principais atividades econômicas da atualidade, a aproximação entre aquele que chega e aquele que recebe se tornou uma de suas principais características. A hospitalidade pública de um destino, por estar intrinsicamente ligada a essa interação, necessita ter sua infraestrutura organizada no espaço, propiciando ao anfitrião e ao visitante livre acesso, autonomia e segurança.

Uma vez identificado o objetivo desse estudo, analisar como a Hospitalidade Pública se manifesta na Praça Gustavo Teixeira a partir da observação das relações entre moradores e turistas ou visitantes, as considerações citadas no capítulo anterior poderão contribuir para o planejamento turístico da cidade.

As visitas são diárias, em alguns momentos acontecem por mais de uma vez, e as motivações diversas: trabalho, lazer, bem-estar. As lembranças de momentos vividos são citadas por todos os entrevistados e demostram o quanto esse lugar foi e é importante no decorrer da vida. Tais ações mostram o pertencimento ao espaço turístico, por parte do anfitrião, citado por autores como Montandon (2004).

A interação entre moradores e turistas acontece constantemente. Pessoas conhecidas utilizam os bancos da Praça como ponto de encontro, sendo os assuntos os mais diversos possíveis. Anfitriões e visitantes também estabelecem relação, seja no espaço de estudo ou no comércio do entorno. Torna-se nítida a hospitalidade nessas ações, além de exemplificar o estudo Bell (2007) que afirma existir hospitalidade urbana em empresas que localizam-se próximas a espaços turísticos públicos.

Referindo-se as dimensões da hospitalidade pública, citadas por Grinover (2007), o grupo de anfitriões refere-se a acessibilidade física como existente e sua maior parte positiva. Ruas pavimentadas; sinalização; pontos de ônibus circulares e táxi no entorno; localização no centro da cidade tornam o espaço acessível a moradores e turistas. A acessibilidade intangível foi citada como ponto negativo para uma moradora, pois turistas buscam por informações em seu comércio e alguns deixam de participar das atividades promovidas no espaço de estudo.

A leitura acerca da dimensão da legibilidade foi realizada de forma parecida por todos do grupo. Símbolos e elementos que caracterizam a praça, segundo autores como Moreno (2002), foram mencionados: coreto, bancos, arborização, espaço verde em meio ao urbano, utilização para lazer e recreação e comércio. A arborização e o paisagismo, por sua vez, receberam uma consideração sobre podas e manutenção, algo a se melhorar. Nesse momento da análise, descrições físicas se entrelaçaram com histórias de vida. Tornou-se nítido, novamente, o sentimento de pertencimento. Grinover (2006, p.35) reforça a importância do 
pertencer 'O pertencimento é vital: 'despertencidos' e desapropriados de nossas raízes perambulamos por nossas cidades, sem mitos fortes que nos amarrem, nossas heranças se perderam e não temos o que colocar no lugar".

A identidade não esteve presente somente na abordagem dessa dimensão. Diversas foram as falas que a exemplificaram no decorrer das entrevistas, essencialmente nos fatores históricos e nos costumes - que remetem a momentos familiares. Para Grinover (2007, p.150) a identidade poder ser descrita como "algo vivo, sempre em uso, necessário e amado, lugares de confluências das memórias passadas e, sobretudo, das memórias futuras”. Por ser considerada uma cidade pequena do interior, São Pedro (SP) precisa manter características que a tornem interiorana, estendendo-se a praça. Essa identidade foi citada, como existente, inúmeras vezes - tranquilidade, segurança, atividades de cidade pequena. Atividades musicais realizadas nos dias de hoje, como a "Música na Praça", foram relatadas como parte da história - antigamente bandas municipais tocavam no coreto e as famílias saiam de suas casas para assistir. Outras atividades artísticas, como teatro de rua, estão na história local, pois o Jardim Público foi construído com recursos provenientes de apresentações do grupo de teatro da cidade. Por fim, o poeta são-pedrense Gustavo Teixeira, que dá nome à Praça, é lembrado em atividades promovidas pela rede municipal de ensino como a Voltinha Literária; a Leitura na Praça e a Semana Literária "Gustavo Teixeira".

As falas dos visitantes foram analisadas em um segundo momento. Alguns visitam a Praça sempre que estão na cidade e outros lá estiveram pela primeira vez. Os passeios são motivados por lazer e descanso e, em alguns trechos das entrevistas, memórias da infância vivida em outras praças foram relatadas.

No ponto de vista dos turistas, a interação com o anfitrião existe não somente no espaço público, mas em hotéis, pontos de informações turísticas e comércios próximos a Praça. Cumprimentos cordiais e sorrisos são frequentes no local, além do atendimento gentil no entorno. A importância dessa relação está na essência do conceito da hospitalidade trazida por inúmeros autores citados nesse estudo.

Ao serem questionados sobre a dimensão da acessibilidade, os visitantes relatam que a acessibilidade física possui pontos positivos como localização no centro da cidade; qualidade do asfalto e ponto de táxi. Porém, a acessibilidade para deficientes físicos deixa a desejar, uma vez que as rampas para cadeirantes não permitem o acesso de maneira segura e os pisos táteis encontram-se desnivelados. A acessibilidade intangível, por sua vez, foi citada de forma positiva por meio de redes sociais e do comércio local. 
A legibilidade foi mencionada, semelhante a alguns moradores, com relatos de lembranças da infância: brincadeiras no interior do local; encontro com amigos. Comparações com praças de outras cidades também foram feitas: área arborizada; flores; localização no centro da cidade; bancos; coretos. Ainda enquanto área arborizada, o vento e a brisa foram citados como conforto, uma vez que nos dias de hoje esse conforto é reduzido ao material. Camargo (2008, p. 22) afirma "O investimento estético - de qualquer natureza - em ruas, as praças, os monumentos e a sua infraestrutura de recepção e circulação, é uma manifestação regida pelo sistema da dádiva. A cidade se faz mais bonita e exibe sua beleza como dádiva aos que nela moram e aos que a visitam". Para outros turistas, o espaço possui características de uma cidade do interior: tranquilidade e sossego.

A última dimensão abordada foi a identidade. Ao observar os passeios dos anfitriões atualmente, alguns turistas recordaram dos footings - passeios entre moças e rapazes com o intuito de paquerar. O comércio do entorno também foi citado, pois expõem artesanatos, bordados ponto-cruz e gastronomia caipira que fazem parte da história de São Pedro. A interação entre as pessoas, conhecidas ou não, foi outro ponto abordado, sendo característica de cidade do interior.

Concluídas as análises das entrevistas, o objetivo do estudo em analisar como a hospitalidade pública se desenvolve na Praça Gustavo Teixeira foi alcançado. As dimensões de acessibilidade, legibilidade e identidade, norteadoras da pesquisa, são percebidas no espaço tanto por moradores quanto por turistas. Pontos positivos e negativos, de possíveis melhorias, foram identificados e poderão nortear novas políticas públicas voltadas à atividade turística. A interação entre esses dois grupos existe nesses momentos e o bem receber por parte dos anfitriões tornou-se nítido em diversos momentos. 


\section{REFERÊNCIAS}

Arquivo Histórico Municipal de São Pedro. (AHM-SP) Atas da Câmara Municipal de São Pedro: 1884, 1885, 1888, 1900, 1905, 1906, 1908, 1909, 1910, 1911, 1913, 1918, 1936.

. Documentos Diversos sobre Gustavo Teixeira.

. Recortes de Jornais Diversos sobre Gustavo Teixeira.

. Livro do Imposto sobre o café, 1916 a 1918.

. Livro do Imposto sobre o café, 1920 a 1932.

BENI, M. C. Analise estrutural do turismo. São Paulo: Editora SENAC, 2000.

BARRETTO, M. Manual de Iniciação ao Estudo do Turismo. Campinas: Papirus, 1995.

BELL, D. Hospitality and Urban Regeneration In Hospitality: a social lens. University of Stirling, UK, 2007.

BOULLÓN, Roberto C. Planificación del espacio turístico. México: Editorial Trillas, 1983. . Planejamento do espaço turístico. Bauru: EDUSC, 2002.

BRASIL, Ministério do Turismo. Coordenação Geral de Regionalização. Programa de Regionalização do Turismo - Roteiros do Brasil: Módulo Operacional 7 - Roteirização Turística. Brasília: Ministério do Turismo, Secretaria Nacional de Políticas de Turismo, 2007.

BROOKES, M. Modelando o paladar gastronômico: a influência das empresas de alimentação (Somos o que comemos ou o que somos persuadidos a comer?). In: SLOAN, D. (Org.). Gastronomia, restaurantes e comportamento do consumidor. Tradução Sonia Bidutte. Barueri/SP: Manole, 2005.

CAIUBY, Junio. Resenha Histórica de São Pedro. IN: Jornal Caldas de São Pedro: 03 de janeiro de 1937.

CAMARGO, L. O. L. Os interstícios da hospitalidade. Revista Hospitalidade, São Paulo, v. XII, n. especial, p. 42-69, 2015.

Hospitalidade. In: TRIGO, L. G. G. (org.). Análises Regionais e Globais do Turismo Brasileiro. São Paulo: Roca, 2005a.

. Hospitalidade. Coleção ABC do Turismo. São Paulo: Aleph, 2005 b.

. Hospitalidade sem sacrifício? O caso do receptivo turístico. Revista Hospitalidade, São Paulo, ano III, n. 2, p. 11-28, 2. sem. 2006.

51, jul.- dez. 2008.

A pesquisa em hospitalidade. Revista Hospitalidade. São Paulo, ano V, n. 2, p. 15- 
CARlOS, A. F. A; CRUZ, R. C. A; RIBEIRO, A. C. T; YÁZIGI, E. Turismo: espaço, paisagem e cultura. São Paulo: Hubitec, 2000.

CASTELLI, Geraldo. Gestão Hoteleira. São Paulo: Saraiva, 2005.

CHIARINI, Ayrton. Resenha Histórica do Município de São Pedro. São Paulo: Michalany, 1970.

CHON, Kye-Sun, SPARROWE, Raymond T. Hospitalidade: Conceitos e Aplicações. São Paulo: Pioneira Thomson Learning, 2003.

COULANGES, Fustel. A cidade antiga: estudos sobre o culto, o direito, as instituições da Grécia e de Roma. Trad. José Camargo Leite e Eduardo Fonseca. São Paulo: HEMUS, 1975.

CRUZ, Rita de Cássia Ariza da. Hospitalidade turística e fenômeno urbano no Brasil: considerações gerais In: DIAS, Célia Maria de Moraes (org). Hospitalidade: Reflexões e Perspectivas. São Paulo: Manole, 2002.

DENCKER, Ada de Freitas Maneti. Planejamento e Gestão em turismo e hospitalidade. São Paulo: Pioneira Thomson Learning, 2004.

DERRIDA, Jacques. De l'hospitalité,Anne Dufourmantelle invite Derrida à répondre. Paris: Calmann-Levy, 1977.

DIAS, R. Introdução ao turismo. São Paulo: Atlas, 2005.

DORIZOTTO, Frei Sermo. Recreio do Corumbataí no Picadão de Luís Pedroso de Barros. IN: Revista do Instituto Histórico e Geográfico de Piracicaba. Piracicaba: Degaspari, Ano XII, $\mathrm{n}^{\mathrm{o}} 12,2005$.

Recreio do Corumbataí no Picadão de Luís Pedroso de Barros. IN: Revista do Instituto Histórico e Geográfico de Piracicaba. Piracicaba: Degaspari, Ano XIII, $\mathrm{n}^{\mathrm{o}}$ 13, 2006.

EXUPÉRY, Antoine de Saint. O Pequeno Príncipe. Tradução de Dom Marcos Barbosa. 29a ed. Rio de Janeiro. Agir Editora, 1986.

GIL, Antônio Carlos. Como elaborar projetos de pesquisa. São Paulo: Atlas, 2007.

GODBOUT, Jacques T. Introdução à dádiva. RBCS, São Paulo, 1998.

GOOGLE EARTH. Cidade de São Pedro, SP. Disponível em $<$ http//www.googleearth.com.br>. Acesso em 30 outubro de 2016.

GOTMAN, Anne. La question de l'hospitalitéaujourd'hui.Communications 65. Paris, Seuil, 1997

GOTMAN, Anne. O turismo e a encenação da hospitalidade. In BUENO RAMOS \& CAMARGO. Modernidade, cultura material e estilos de vida. São Paulo: Ed. SENAC, 2008, p.115-134. 
GRINOVER. Lucio. A hospitalidade urbana: acessibilidade, legibilidade e identidade. Revista Hospitalidade, (2006).

. Hospitalidade, a cidade e o turismo. São Paulo: Aleph, 2007.

A Hospitalidade na perspectiva do espaço urbano. In: Revista Hospitalidade. Ano VI, no 1, junho de 2009.

. Hospitalidade, qualidade de vida, cidadania, urbanidade: novas e velhas categorias para a compreensão da hospitalidade urbana. RITUR-Revista Iberoamericana de Turismo, 2013.

. A cidade a procura da hospitalidade. São Paulo: Aleph, 2016.

Hospitalidade: um tema a ser reestudado e pesquisado. In: DIAS, Célia Maria M. (org.). Hospitalidade: reflexões e perspectivas. Barueri: Manole, 2002.

GUERRINI, Leandro. História de Piracicaba em Quadrinhos. Edição do Instituto Histórico e Geográfico de Piracicaba. Piracicaba: Imprensa Oficial do Município de Piracicaba, vol. I, 1970.

GUERRINI, Leandro. História de Piracicaba em Quadrinhos. Edição do Instituto Histórico e Geográfico de Piracicaba. Piracicaba: Imprensa Oficial do Município de Piracicaba, vol. II, 1970.

GUERRINI, Leandro. História de Piracicaba: antes de sua fundação. IN: Piracicaba Noiva da Colina. Piracicaba: Editora Aloisi, 1975.

IBGE - Instituo Brasileiro de Geografia e Estatística. Cidade de São Pedro, SP. Disponível em <http//www.ibge.gov.br>. Acesso em 20 de junho de 2016.

KAUARK, Fabiana da Silva; MANHÃES, Fernanda Castro; MEDEIROS, Carlos Henrique. Metodologia da Pesquisa, um guia prático. Bahia: Editora Via Litterarum, 2010.

LASHLEY, Conrad; MORRISON, Alisson. Em busca da hospitalidade: perspectivas para um mundo globalizado. Barueri: Manole, 2004.

LOBODA, Carlos Roberto. Estudo das áreas verdes urbanas de Guarapuava-PR. 2003. Dissertação (Mestrado em Geografia). Universidade Estadual de Maringá, Maringá/PR.

MANO, Marcel. Os Campos de Araraquara: Um estudo de história indígena no interior paulista. Trabalho como requisito para a obtenção do titulo de Doutor. Campinas: UNICAMP, 2006.

MARCONI, Marina de Andrade; LAKATOS, Eva Maria. Fundamentos de Metodologia Científica. São Paulo, Editora Atlas, 2003.

MAUSS, Marcel. Sociologia e antropologia. São Paulo: Cosac \& Naify, 2003. 
MONTANDON, Alain. O Livro da Hospitalidade: acolhida do estrangeiro na história e nas culturas. São Paulo, Editora Senac, 2004.

MORENO, Júlio. O futuro das cidades. São Paulo. Ed. SENAC, 2002.

MOURTHÉ, Claudia. Mobiliário urbano. Rio de Janeiro: 2AB, 1998.

OLIVEIRA, M. da S. Gestão de restaurantes: uma prática de hospitalidade. Mestrado em Hospitalidade. São Paulo: Universidade Anhembi Morumbi, 2006. Disponível em: $\langle$ http://tede.anhembi.br/tedesimplificado//tde_busca/arquivo.php?codArquivo=91 $>$.

Acesso em: 03 set. 2016.

PANOSSO NETTO, A. O que é turismo. São Paulo: Editora Brasiliense, 2010.

PANOSSO NETTO, A.; LOHMANN, G. Teoria do Turismo: conceitos, modelos e sistemas. $1^{\circ}$ reimpressão. São Paulo: Aleph, 2011.

PLENTZ, R. S. Dialética da Hospitalidade: Caminhos para a Humanização. Caxias do Sul, 2007. 208 p. Dissertação (Mestrado) - Programa de Pós-graduação e Mestrado em Turismo. Universidade de Caxias do Sul, Rio Grande do Sul, 2007.

ROBBA, F; MACEDO, S. S. Praças brasileiras - Public Squares in Brazil. São Paulo: Imprensa Oficial, 2003.

SANTOS, Rodrigo Luíz dos. São Pedro: Educação, Cultura e Turismo. São Paulo: Noovha América, 2009.

SÃO PAULO, Secretaria de Turismo. Estâncias Turísticas. São Paulo, 2016. Disponível em: http://www.turismo.sp.gov.br. Acesso em 20 jun. 2016.

SÃO PEDRO, Prefeitura Municipal. Plano de Saneamento Básico. São Pedro, 2013.

SÃO PEDRO, Prefeitura Municipal. Plano Diretor de Turismo. São Pedro, 2015.

SEVERINI, V. F. (2014). Hospitalidade urbana: ampliando o conceito. RITUR-Revista Iberoamericana de Turismo.

SILVA, Maria da Glória Lanci. Cidades turísticas: identidades e cenários de lazer. São Paulo: Aleph, 2004.

SMITH, Valene. (Ed.). Hosts and guests: the anthropology of tourism. 2. ed. Philadelphia: University of Pennsylvania Press, 1989.

SPOLON, Ana Paula. Um exercício de hospitalidade. Revista Hospitalidade. São Paulo, ano V, n. especial, maio 2015.

URRY, John. O olhar do turista. São Paulo: Nobel, 1996.

VALLS, Josep-Francesc. Gestão integral de destinos turísticos sustentáveis. Tradução: Cristiano Vasques e Liana Wang. Rio de Janeiro: Editora FGV, 2006. 
WALKER, J. R. Introdução à hospitalidade. Barueri: Manole, 2002.

YÁZIGI, Eduardo. A alma do lugar. Turismo, planejamento e cotidiano. Ed: Contexto. 2001. 


\section{APÊNDICE A - ROTEIRO DE ENTREVISTA ANFITRIÃO}

1 - Nome

2 - Idade

3 - Origem

4 - Profissão

5 - Com que frequência visita a Praça?

6 - Qual motivação em visitar a Praça?

7 - Acha a Praça acolhedora?

8 - Existe relação entre moradores enquanto estão no local? E com o visitante? Caso sim, os anfitriões são hospitaleiros?

9 - A Praça, enquanto espaço público, é um ambiente acessível para moradores e turistas? (Acesso às atividades? Acesso às informações? Sinalização? As vias de acesso até o local permitem a locomoção? Sua localização quanto ao transporte urbano é viável? Acesso ao transporte particular - táxi - é possível? Acesso a deficientes físicos?)

10 - A Praça, enquanto espaço público, identifica-se visualmente com o significado de Praça? Os caminhos, os itens contidos e as atividades desenvolvidas no local o caracterizam como Praça? Se faz perceptível melhorias para tornar a Praça um espaço melhor?

11 - A Praça, enquanto espaço público, possui o espírito de pertencimento das pessoas que nela convivem? A história, o hábito e a cultura dos moradores são mantidos? Passado e presente caminham juntos? 


\section{APÊNDICE B - ROTEIRO DE ENTREVISTA VISITANTE}

1 - Nome

2 - Idade

3 - Origem

4 - Profissão

5 - Com que frequência visita a Praça?

6 - Qual motivação em visitar a Praça?

7 - Acha a Praça acolhedora?

8 - Existe relação entre moradores e visitante? Caso sim, os anfitriões são hospitaleiros?

9 - A Praça, enquanto espaço público, é um ambiente acessível? (Acesso às atividades? Acesso às informações? Sinalização? As vias de acesso até o local permitem a locomoção? Sua localização quanto ao transporte urbano é viável? Acesso ao transporte particular - táxi é possível? Acesso a deficientes físicos?)

10 - A Praça, enquanto espaço público, identifica-se visualmente com o significado de Praça? Os caminhos, os itens contidos e as atividades desenvolvidas no local o caracterizam como Praça? Se faz perceptível melhorias para tornar a Praça um espaço melhor?

11 - A Praça, enquanto espaço público, possui o espírito de pertencimento das pessoas que nela convivem? A história, o hábito e a cultura dos moradores são mantidos? Passado e presente caminham juntos? 